\title{
MOŻLIWOŚCI I FORMY DUSZPASTERZOWANIA SALEZJANÓW W POWOJENNEJ RZECZYWISTOŚCI NA TERENACH EUROPEJSKICH REPUBLIK RADZIECKICH
}

\section{Wprowadzenie}

W lutym 1945 roku wielka trójka na konferencji w Jałcie zdecydowała o oderwaniu od Polski na rzecz Związku Sowieckiego ziem na wschód od linii Wilno-Grodno-Bug-Przemyśl. W celu uregulowania problemów związanych z likwidacją skutków II wojny światowej i organizacją powojennej Europy, ta sama Trójka na przełomie lipca i sierpnia tego roku w Poczdamie zdecydowała o przyznaniu Polsce Ziem Zachodnich i Północnych z Gdańskiem i części Prus Wschodnich (bez Królewca) oraz potwierdziła oddanie Związkowi Sowieckiemu ziem polskich na wschód od Niemna, Bugu i Sanu.

Po zakończeniu wojny światowej i przesunięciu granicy naszego państwa ze wschodu na zachód terytorium naszego kraju uległo zmniejszeniu o 20\%, a 181 tys. $\mathrm{km}^{2}$ ziem wschodnich zostało przyłączonych do Związku Radzieckiego. Zdziesiątkowane przez okupanta niemieckiego i sowieckiego społeczeństwo polskie, w lutym 1945 roku określiło się liczbą 20,5 mln obywateli. Z tej liczby $5 \mathrm{mln}$ Polaków żyło wówczas poza granicami proklamowanej Polskiej Rzeczypospolitej Ludowej. Przedwojenni mieszkańcy Kresów nakłaniani byli do tzw. repatriacji i wyjazdu do PRL-u. Wielu Polaków, w tym i kapłanów, było zmuszanych do opuszczenia swoich domostw i placówek duszpasterskich na tamtych terenach. Pewna część ludności cywilnej i duszpasterzy w ramach repatriacji wyjechała do PRL-u. Decyzje duchowieństwa o wyjeździe z byłych już Kresów nie zawsze były pozytywnie oceniane przez Rodaków tam pozostających ${ }^{1}$.

Tylko z archidiecezji wileńskiej, największej w II Rzeczypospolitej, w ramach tzw. repatriacji w 1945 roku wyjechało 112 kapłanów, z ogólnej liczby 212 kapła-

* Ks. Waldemar Żurek - dr historii Kościoła, adiunkt, sekretarz naukowy Instytutu Archiwów Bibliotek i Muzeów Kościelnych w KUL.

${ }^{1}$ B. Kumor, Historia Kościoła. Czasy wspótczesne 1914-1992, cz. 8, Lublin 1996, s. 474-475 . 
nów-Polaków tam pracujących. Większość salezjanów pracujących do 1945 roku na Wileńszczyźnie wróciła do Polski. Pozostało tam 9 salezjanów, którzy do końca swego życia pracowali w tamtejszym duszpasterstwie, należąc chociażby nominalnie do salezjańskiej Prowincji św. Stanisława Kostki. Do nich należeli księża: Michał Bulowski, Bronisław Chodanionek, Kazimierz Ryszard Grzegorczyk, Tadeusz Hoppe, Ryszard Stohandel, Jan Franciszek Tokarski, Stanisław Toporek, Jan Wielkiewicz i Ludwik Witkowski. Ks. Jan Kapusta, przełożony domu i proboszcz parafii Bożego Ciała w Dworcu Nowogródzkim, aresztowany przez Sowietów 27 IX 1939 roku, odbywał karę zsyłki na Syberii, następnie przymusowego osiedlenia w Kazachstanie i Uzbekistanie. Powrócił do Polski dopiero 30 XII 1955 roku. Jako pracownik fizyczny w kołchozie pracował w Rubnie k. Wilna brat zakonny (koadiutor) Wojciech Wiertelak. Po śmierci pozbawionego majątku obszarnika Jana Obsta, z którym mieszkał w prywatnie wynajętym mieszkaniu, powrócił do Polski w 1959 roku. $^{2}$

Z przedwojennych placówek salezjańskiej Prowincji św. Jacka rozsianych na terenie archidiecezji lwowskiej, w Ukraińskiej SRR nie pozostał po 1945 roku żaden salezjanin.

Największą liczbę domów salezjanie polscy utracili w 1945 roku w Ukraińskiej SRR - 5: Brodki (filia Lwowa), Daszawa, Drohowyże, Lwów (dwa); w Litewskiej SRR - 4: Kamienny Most, Kurhan, Wilno (dwa); w Białoruskiej SRR - 2: Dworzec i Reginów. Najdrastyczniej proces „opuszczania placówek” przez salezjanów przebiegał w republice ukraińskiej. W sumie dwie prowincje salezjańskie: św. Stanisława Kostki i św. Jacka utraciły po 1945 roku na Wschodzie jedenaście przedwojennych placówek ${ }^{3}$.

Salezjanie, którzy zdecydowali o pozostaniu po wojnie na terenach litewskiej i białoruskiej republiki radzieckiej, starali się zatrzymać w tych placówkach gdzie pracowali do 1945 roku lub w najbliższej okolicy. W Litewskiej SRR duszpasterzowali: Bronisław Chodanionek, Tadeusz Hoppe, Stanisław Toporek. $\mathrm{Z}$ upływem lat, sterani pracą, życiem w ustawicznym strachu i stresie oraz nękani chorobami, umierali. W Białoruskiej SRR pracowali księża: Ludwik Bulowski, Kazimierz Grzegorczyk, Ryszard Stohandel, Jan Tokarski, Jan Wielkiewicz, Ludwik Witkowski. Niektórzy z nich z czasem rozproszyli się po terytorium Związku Sowieckiego. Do Mołdawskiej SRR wyjechał w 1949 roku ks. Bronisław Chodanionek. Do Odessy nad Morzem Czarnym z Ławarywszek k. Wilna wyjechał w grudniu 1958 roku ks. Tadeusz Hoppe. Ks. Ryszard Stohandel w 1959 roku powrócił do Polski.

Salezjanie na Wileńszczyźnie jeszcze w 1948 roku uważani byli przez przełożonych w Polsce jako pozostający poza Zgromadzeniem. Na miarę możliwości, przy wykorzystaniu nadarzających się okazji i przy zachowaniu wszelkich środków ostrożności, kontaktowali się z przełożonymi w kraju, by w ten sposób

${ }^{2}$ S. Wilk, Salezjanie, w: Życie religijne w Polsce pod okupacja hitlerowska 1939-1945, red. Z. Zieliński, Warszawa 1982, s. 733-735.

3 S. Rozner, W. W. Żurek, Salezjanie we Lwowie w latach 1934-1945, „Archiwa Biblioteki i Muzea Kościelne", 68 (1997) s. 404-405. 
potwierdzać łączność zakonną ze Zgromadzeniem, w którym złożyli profesję wieczystą ${ }^{4}$.

Na całym obszarze ZSRR w drugiej połowie XIX w. istniały tylko dwa katolickie seminaria duchowne: w Kownie (Litewska SRR) i Rydze (Łotewska SRR). Przyjęcie do tych seminariów kandydatów z poszczególnych republik imperium rosyjskiego było „reglamentowane” przez władze państwowe.

Przestępstwem było zawarcie ślubu kościelnego, ochrzczenie dziecka. Za tego rodzaju ,przestępstwa” zwalniano z pracy, wyrzucano ze studiów, uniemożliwiano awans zawodowy.

Rozpędzono klasztory, uniemożliwiano siostrom zakonnym życie we wspólnotach zakonnych i gromadzenie się na wspólne praktyki pobożne. Pozbawiano ich środków do życia. Siostry żyły w rozproszeniu i tylko potajemnie mogły się spotykać od czasu do czasu na wspólną modlitwę. Stały się żebraczkami. Jeżeli udało im się otrzymać pracę, to najbardziej poniżającą. Dużą pomoc w tamtych czasach okazywali im księża oraz wierni. Obowiązywał zakaz pokazywania się w sutannach i habitach zakonnych. Zabronione było kapłanom przygotowywać dzieci do I Komunii św. i do bierzmowania. Za tego rodzaju „działalność wywrotową" spadały na księży dotkliwe sankcje, jak: kary pieniężne, zakaz sprawowania funkcji kapłańskich (odprawiania Mszy św., spowiadania, udzielania komunii św.). Bywało tak, że kapłan w niedzielę nie mógł stanąć przy ołtarzu, tylko razem $\mathrm{z}$ wiernymi klecząc $\mathrm{w}$ ławce odmawiał różaniec święty. Nawet po śmierci księdza trzeba było uzyskać pozwolenie na dzwonienie dużym dzwonem ${ }^{5}$.

Nie wolno było urządzać żadnych procesji, poświęcenia cmentarzy, poza wnętrzem kościoła nie wolno było sprawować czynności liturgicznych, jeśli w tej parafii kapłan posiadał tzw. sprawkę do sprawowania funkcji kapłańskich. Jeżeli święta Bożego Narodzenia przypadły w dzień powszedni, to był to normalny dzień pracy. Gromadzenie się na wspólny rożaniec czy litanię loretańską, np. przy kapliczkach przydrożnych, uznawano za działalność wywrotową.

Usuwano krzyże przydrożne i palono. Zrywano krzyże z wież kościołów. Wywożono do muzeów obrazy z kościołów, figury, dzwony, przedmioty kultu. Wielu ze zrabowanych przedmiotów nie zwrócono do dziś. Gdy zmarł ksiądz, a wierni chcieli korzystać ze świątyni, aby gromadzić się w niedzielę i „sami odprawiać Mszę św.”, musieli płacić podatek za posiadanie kościoła. Podatki podnoszono do tak ogromnych sum, że niskie zarobki wiernych często nie pozwalały na ich zapłacenie. Młodych aktywistów księży wcielano do wojska, pomimo że ich wiek służby wojskowej już minął ${ }^{6}$.

Najbardziej palącym problemem Kościoła katolickiego w Europie ŚrodkowoWschodniej w drugiej połowie XX w. było duszpasterstwo na terenie ZSRR, a szczególnie na terenie Ukraińskiej, Białoruskiej i Litewskiej Republice

${ }^{4}$ W. W. Żurek, Jeńcy na wolności. Salezjanie na terenach byłego ZSRR po II wojnie światowej, Kraków 1998, s. 11.

${ }^{5} \mathrm{Na}$ przykład po śmierci w Zdzięciole (†12 III 1969) salezjanina, ks. Jana Wielkiewicza uzyskano pozwolenie na pociągnięcie tylko siedem razy za linkę dzwonu. Ks. Bernard Kamiński do ks. W. Żurka z 5 X 2006 roku - Lutomiersk (zb. aut.).

${ }^{6}$ Ks. Bernard Kamiński do ks. W. Żurka z 5 X 2006 roku - Lutomiersk (zb. aut.). 
Radzieckiej. W tych republikach żył spory procent katolików, a liczne kościoły nie były obsadzone przez duszpasterzy. Tylko w niektórych pracowali księża, którzy z powodu wieku i dolegliwości zdrowotnych nie mogli podołać obowiązkom duszpasterskiem. W Rzymie dyskutowano w odpowiednich kręgach jak działać aby utrzymać przynajmniej ówczesny stan rzeczy. W oczach władz kościelnych Polska, a szczególnie zakony w Polsce, winne dążyć do tego, aby przygotować odpowiednią kadrę i nie zmarnować żadnej okazji do przerzutu księży na tereny wschodnie. Specjalne zadanie w tym względzie mieli: jezuici, redemptoryści, salezjanie i pallotyni. Prymas Polski, kard. Stefan Wyszyński, poprzez Komisję do Spraw Wschodu kierował „sektorem wschodnim”. Stolica Apostolska organizowała we Włoszech seminaria, które kształciły księży do pracy na Wschodzie?.

Księża przy okazji wyjazdów do ZSRR na zaproszenie od rodziny, przeprowadzali tam sondaże i pisali spostrzeżenia władzom kościelnym w Polsce. Także poprzez zaufanych turystów udających się na Wschód przekazywano tam informacje na temat życia Kościoła powszechnego, wprowadzania uchwał Soboru Watykańskiego II, ważniejszych nominacji stolic biskupich i urzędów w Kościele itp.

Pod koniec lat 60. ubiegłego stulecia pewien salezjanin został wysłany z ramienia Zgromadzenia i księdza Prymasa, aby zbadał możliwości duszpasterzowania na Białorusi. Miał się również zorientować, czy istnieje możliwość przerzutu młodych salezjanów na Białoruś. W rozmowie z księdzem Prymasem, przed wyjazdem, dowiedział się, że są rozpaczliwe wołania ze strony tamtejszych księży. Ksiądz Prymas zaopatrzył go w odpowiedni dokument, którym miał się legitymować przed tamtejszym duchowieństwem. Od biskupa Jerzego Modzelewskiego, sufragana warszawskiego otrzymał ustną instrukcję na temat ubiegania się o pozwolenie na odprawianie praktyk religijnych u władz państwowych. Udał się w okolice Lidy i miał zebrać informacje na temat: 1) jaki jest stosunek władz ZSRR do Kościoła; 2) jaki jest faktyczny stan Kościoła na Białorusi; 3) ile procentowo żyje w Lidzie i okolicy katolików; 4) czy księża na tym terenie należycie wypełniają obowiązki duszpasterskie. Miał także dać nadzieję tamtejszym wiernym, że przyjadą z Polski młodzi księżå.

Autor niniejszego raportu udał się do miejscowości Krupowo koło Lidy, na Białorusi. Złożył u księdza dziekana w Lidzie wizytę, a w trakcie rozmowy dowiedział się, że dziekan prowadzi duszpasterstwo na terenie całego powiatu lidzkiego oraz to, że ksiądz dziekan ma wszystkie uprawnienia jurysdykcyjne,

\footnotetext{
${ }^{7}$ Na przedmieściach Rzymu salezjańskie Kolegium Ukraińskie kształci do dziś kandydatów do kapłaństwa w Zgromadzeniu Salezjańskim w obrządku bizantyjsko-ukraińskim. Jego rektorem był w latach 70. ubiegłego stulecia ks. Vladimiro Hrynyszyn, salezjanin, rodem z Ukrainy. Często przyjeżdżał do Polski (Lwowiec, pow. Bartoszyce) pod pozorem odwiedzenia rodziny, ale celem jego przyjazdów było zdobycie informacji o sytuacji Kościoła na Ukrainie. Archiwum Akt Nowych (dalej: AAN), Urząd do Spraw Wyznań (dalej UdSW), sygn. 133/157, Duszpasterstwo w ZSRR, notatka-raport sporządzony przez byłego salezjanina (podpis nieczytelny), który przed 1969 roku „wizytował" Kościół w okolicach Lidy na Białorusi z 23 VIII 1971 roku - Gdańsk, s. 107 (zb. aut.).

${ }^{8}$ AAN, UdSW, sygn. 133/157, Duszpasterstwo w ZSRR, notatka-raport z 23 VIII 1971 roku Gdańsk, s. 107-108 (zb. aut.).
} 
jak biskup. Kościoły, w których nie było księży, miały cichych diakonów, którzy mieli prawo prowadzić nabożeństwa, głosić kazania, chrzcić i opiekować się Eucharystią w tabernakulum. Z rozmowy z księdzem dziekanem wynikało, że na Białorusi pracuje zakonspirowany biskup. Po powrocie z Białorusi ów nieznany nam z nazwiska salezjanin zdał ustne sprawozdanie biskupowi Modzelewskiemu w Zakopanem. W marcu 1969 roku usilnie nalegano na autora przedstawionego raportu, aby starał się o wyjazd do ZSRR na stałe. W Częstochowie obiecano mu udzielić przed wyjazdem święceń biskupich w ścisłej tajemnicy. Z propozycji tej nie skorzysta ${ }^{9}$.

W najtrudniejszych latach komunizmu w Związku Sowieckim jedynym znanym nam salezjaninem, który wyjeżdżał z Polski na Wschód, na przestrzeni 20 lat (do Ukraińskiej i Litewskiej Socjalistycznej Republiki) był ks. Edward Mazur ${ }^{10}$, którego rodzice pochodzili z lwowskiego. Swoje wyjazdy rozpoczął w 1964 roku od odwiedzenia stron rodzinnych. Zaproszenie przysłał mu Ukrainiec, grekokatolik, z którym spotkał się na Dolnym Śląsku z okazji jego odwiedzin u rodziny. $\mathrm{Na}$ to zaproszenie ks. Edward wyjechał i zameldował się u zapraszającego. Nie chcąc przysparzać jemu i rodzinie niepotrzebnych „kłopotów” gość z Polski wyjeżdżał w teren z posługą duszpasterską. Jeździł zawsze z obstawą i samochodem na miejscowych rejestracjach i w towarzystwie osób zaufanych.

Zanim Michaił Gorbaczow został I sekretarzem KC KPZR i zanim nastąpił rozpad ZSRR, położenie Kościoła katolickiego w Związku Sowieckim było niezmiernie trudne. W okresie komunistycznym przestały istnieć struktury kościelne. Wiele kościołów zrównano z ziemią a ogromną ilość zamieniono na: szpitale, magazyny kołchozowe (w tym nawozów i środków chemicznych), warsztaty, szkoły, hale sportowe, domy kultury, kina lub też pozostawiono na pastwę losu. Grabiono i dewastowano obiekty sakralne.

Kilkanaście lat przed zapaleniem się ,zielonego światła” dla działalności kościelnej na Wschodzie ryzykowne i odważne podróże na Litwę, Białoruś, Ukrainę i do Rosji podejmowali Delegaci Przełożonego Generalnego dla Prowincji Polskich: ks. Stanisław Rokita (1972-1978) i ks. Augustyn Dziędziel (1978-1996) 11. Żyli tam jeszcze nieliczni przedwojenni salezjanie, którzy w ramach ekspatriacji nie wrócili do proklamowanej w 1945 roku Polski Ludowej. Ks. Rokita

9 Tamże, s. 2.

${ }^{10}$ Ks. Mazur Edward, salezjanin, ur. 29 XII 1926 roku w miejscowości Chłopy, pierwszą profesję złożył 15 VIII 1948 roku w Kopcu, święcenia kapłańskie otrzymał 29 VI 1956 roku w Oświęcimiu. Obecnie współbrat Prowincji św. Jana Bosko. Pracuje w Parafii św. Michala Archanioła we Wrocławiu. L. Kaliński, Rodzina Salezjańska w Polsce. Wykaz domów i osób, Warszawa 1988, s. 378.

${ }^{11}$ Ks. Dziędziel Augustyn, ur. 24 IV 1935 roku, profesja 15 VIII 1953 roku, święcenia kapłańskie 19 IV 1959 roku W wieku 35 lat został inspektorem Prowincji św. Jacka na sześć lat (19701976), dwa lata później został mianowany Delegatem Przełożonego Generalnego salezjanów do spraw inspektorii polskich oraz powierzonym tymże inspektoriom zadaniom misyjnym w Zambii i w krajach byłego Związku Radzieckiego. Tę funkcję sprawował przez 18 lat. Nie miał władzy jurysdykcyjnej, ale funkcję raczej informacyjno-koordynacyjną. Kaliński, Rodzina Salezjańska w Polsce, s. 24-25. 
głównie wyjeżdżał na Wileńszczyznę, gdzie Kościół miał nieco swobody, do ks. Stanisława Toporka (zm. 1977) pracującego w Ławaryszkach. Ks. Dziędziel wyruszał i dalej do innych Republik Radzieckich: Białoruskiej, Ukraińskiej i Rosyjskiej. Podróże wysłannika Przełożonego Generalnego Zgromadzenia, ks. Egidio Vigano, miały na celu podtrzymanie więzi duchowej z tymi współbraćmi, którzy tam spalali swoje życie, szukanie nowych powołań lokalnych, potajemna więź z kandydatami w czasie odbywania przez nich studiów, zaopatrywanie ich w materiały formacyjne. Zważywszy na permanentną inwigilację obcokrajowców udających się na Wschód oraz kontrole przy przekraczaniu granic i niewygody podróży, możemy sobie uzmysłowić jakiej odwagi, opanowania nerwów, roztropności, ostrożności i zdrowia potrzeba było ks. Dziędzielowi podejmującemu tak ryzykowne wyjazdy na Wschód ${ }^{12}$.

A kiedy już wyjazdy na Wschód były możliwe, doszedł dla ks. Dziędziela trud wyszukiwania w Polsce współbraci gotowych do pracy w tamtych warunkach. Dalej troska o zabezpieczenie materialne pionierów salezjańskich udających się na Wschód i zakładanych przez nich pierwszych wspólnot zakonnych i placówek duszpasterskich. W tym też czasie zakres obowiązków księdza delegata powiększył się o kraje byłego Związku Radzieckiego. Mówiąc dzisiaj o obecności i pracy salezjanów w krajach byłego Związku Sowieckiego, trzeba podkreślić ogromne zaangażowanie i wkład ks. Augustyna Dziędziela w inspirowanie tej pracy i jej formy do dzisiaj na Wschodzie.

Po dojściu do władzy w Związku Radzieckim Michaiła Gorbaczowa w wyniku ,pierestrojki” zelżało w imperium sowieckim. Po rozwiązaniu w 1991 roku ZSRR dokonały się na Wschodzie nieprzewidziane zmiany. Poszczególne republiki ogłaszały swoją niepodległość. Na ich bazie powstały: Republika Białorusi, Litwa, Rosja, Ukraina i kolejne niepodległe państwa. Za jedną z najistotniejszych zmian należy uznać przemiany w tamtejszym Kościele, w tym w Kościele obrządku łacińskiego. Chociaż w tych państwach pozostało w stosunku do Kościoła komunistyczne prawodawstwo (rejestracja wspólnot parafialnych na określony czas i ponowne starania o rejestrację, komitet kościelny-dwadcatka), wierni mogli swobodnie wyznawać wiarę, mimo że religia katolicka w niektórych państwach nie jest uznawana prawnie przez władze państwowe (Białoruś, Ukraina, Rosja); w przypadku Białorusi na podstawie dawnej tradycji funkcjonują (dopuszczalne są) dwie konfesje: prawosławie i katolicyzm.

Wobec rosnącej liczby reaktywowanych parafii konieczne było zapewnienie obsługi duszpasterskiej przez księży, głównie z zagranicy. Pasterze Kościoła z wspomnianych krajów, mianowani w 1991 roku, zwrócili się w tej sprawie o pomoc do Kościoła katolickiego w Polsce. Było to uzasadnione ze wszech miar i jak się wydaje optymalne wówczas rozwiązanie. Kościół w Polsce dysponował wystarczającą liczbą kapłanów. Językiem życia religijnego społeczności tych krajów był polski, a wszyscy księża z Polski posiadali w miarę dostateczną znajomość potrzebnego na Wschodzie języka rosyjskiego lub możliwość w miarę szybkiego jego opanowania. Ponadto podobieństwo doświadczeń życia w ustroju socjali-

${ }^{12}$ Z. Weder, Znaki nadziei, Warszawa 2004, s. 55-58. 
stycznym predysponowało ich do pracy duszpasterskiej na terenach wschodnich i ułatwiało w miarę szybką adaptację do nowych warunków egzystencji i pracy. Dopiero w późniejszym czasie podjęli tam pracę księża z krajów europejskich, a nawet $\mathrm{z}$ innych kontynentów (USA, Korei Południowej) ${ }^{13}$.

Wychodząc naprzeciw tamtym zapotrzebowaniom, przy zrozumiałym braku miejscowych kapłanów, wielu salezjanów decydowało się na wyjazd do pracy duszpasterskiej na Wschód: na Białoruś, Litwę, Ukrainę, do Rosji, Kazachstanu, Gruzji i dalej. Tam obejmowali głównie parafie, organizowali życie zakonne w erygowanych wspólnotach zakonnych, wreszcie otwierali dzieła z ukierunkowaniem na młodzież, nazywane Centrami lub Ośrodkami Młodzieżowymi oraz salezjańskie Oratoria młodzieżowe.

Stała obecność salezjanów w drugiej połowie XX w. za wschodnią granicą rozpoczęła się od ks. Józefa Zaniewskiego, proboszcza w Żupranach. Parafia w Żupranach stała się kolebką odrodzenia obecności salezjanów na dzisiejszej Białorusi, wkrótce potem na Litwie, Ukrainie, Rosji, Gruzji. Wszelkie inicjatywy rozwojowe Zgromadzenia Salezjańskiego na tamtych terenach przechodziły przez ręce ks. Zaniewskiego, który w angażowaniu salezjanów polskich w tamtejszym duszpasterstwie ma historyczne zasługi ${ }^{14}$

Wyjeżdżający na Wschód salezjanie należeli początkowo do własnych inspektorii salezjańskich $\mathrm{w}$ Polsce, z których pochodzili i podlegali dotychczasowym swoim prowincjałom.

Administracyjnie placówki salezjańskie na Białorusi, Litwie, Ukrainie, Rosji, Gruzji od 1994 roku weszły w skład utworzonego przez Przełożonego Generalnego dn. 8 grudnia tego roku Okręgu Wschodniego pw. Niepokalanego Poczęcia NMP z siedzibą w Moskwie przy ul. Mała Gruzińska 37/66. Przełożony w randze prowincjała (u salezjanów inspektora) kieruje i animuje salezjanów międzynarodowego pochodzenia, pracujących w Okręgu. Pierwszym przełożonym Okręgu Wschodniego został ks. Zdzisław Weder, dotychczasowy inspektor Prowincji św. Stanisława Kostki. Jego następcą w 2000 roku został ks. Henryk Boguszewski. W 2006 roku zastąpił go ks. Giuseppe Pellizzari.

Dziś salezjanie pracują na terenie byłego ZSRR, od Jakucji po Grodno, od Odessy po Sankt Petersburg, również na Litwie i Ukrainie. Współbraci pracujących w Okręgu jest ponad 100. Kandydaci do kapłaństwa studiują we Włoszech, Polsce, Niemczech i Rosji ${ }^{15}$.

W 2004 roku salezjanie litewscy przedstawili prośbę o wyjęcie domów litewskich (Kowno i Wilno) z Okręgu Wschodniego i przyłączenie ich do inspektorii któregoś z państw Unii Europejskiej. Rada Generalna przełożonych w Rzymie

${ }^{13}$ W 1997 roku na Białorusi pracowało księży z Polski ok. 150, na Ukrainie 170, w Rosji Europejskiej i na Syberii 68 (60\% ogółu księży), w Kazachstanie 26 (60\%), na terenach byłego ZSRR ponad 40. R. Dzwonkowski, Od Kościoła polskiego do Kościoła Polaków na Wschodzie, w: Kościót katolicki na Litwie i Białorusi XIX i XX wieku. Sympozjum. Periodyk naukowy, Rok III 1999 Nr 1(4), Kraków 1999, s. 66.

${ }^{14}$ Weder, Znaki nadziei, s. 48.

${ }^{15}$ W. Dąbrowski, Przyjaciel młodych, „Słowo Życia. Gazeta Diecezji Grodzieńskiej”, nr 2 z 30 I 2000 (56), s. 1. 
zdecydowała o przyłączeniu z dniem 15 VIII 2005 roku domów litewskich do włoskiej Inspektorii św. Karola Boromeusza z siedzibą w Mediolanie ${ }^{16}$.

W tym samym roku salezjanie obrządku bizantyjsko-ukraińskiego pracujący na Ukrainie poprosili o erygowanie dla ich domów na Ukrainie (Lwów-dwa, Odessa, Obroshyno) Salezjańskiej Delegatury na Ukrainie, a tym samym wyłączenie ich domów z Okręgu Wschodniego. Przełożony Generalny Zgromadzenia dekretem z dnia 15 VIII 2005 roku erygował dla salezjanów ukraińskich Delegaturę. Jej przełożonym został ks. Onorino Pistellato - Włoch ${ }^{17}$.

Do Delegatury Inspektorialnej Ukrainy należą dwa kanonicznie erygowane domy we Lwowie. Pierwszy na ul. Łyczakowskiej 175, gdzie mieści się siedziba przełożonego Okręgu i funkcjonuje parafia, drugi dom we Lwowie, to Młodzieżowe Ekumeniczne Centrum Nauczania przy ul. Kryvchytska Droga 17 A. Do domu łyczakowskiego należy filia w Obroshynie, oddalonym o $30 \mathrm{~km}$ od Lwowa oraz „Świetlany Dom” w Odessie przy ul. Bazarnej $4^{18}$.

\section{LITEWSKA SOCJALISTYCZNA REPUBLIKA RADZIECKA - LITWA}

\section{a) Salezjanie na radzieckiej Litwie}

Po wkroczeniu Armii Czerwonej do Wilna w lipcu 1944 roku została utworzona Litewska Socjalistyczna Republika Radziecka. Tereny archidiecezji wileńskiej uległy podziałowi między Litewską SRR, Białoruską SRR i Polską Rzeczpospolitą Ludową. W litewskiej części archidiecezji pozostało 79 parafii, 109 kościołów i kaplic, obsługiwanych przez 212 kapłanów. Pozostało na tych terenach po 1945 roku trzech salezjanów, którzy pracowali w tamtejszym duszpasterstwie: Chodanionek, Hoppe i Toporek.

Ks. Bronisław Chodanionek. Po święceniach (8 XII 1941) pełnił obowiązki katechety ${ }^{19} \mathrm{w}$ salezjańskiej placówce litewskiej w Witanach (Vytanai), gdzie funkcjonował od 1938 roku aspirantat zakonny dla wizytatorii litewskiej, utworzonej w 1942 roku dla salezjańskich domów litewskich, które przynależały do

16 Dekret Przełożonego Generalnego o przyłaczeniu domów salezjańskich na Litwie do Inspektorii Lombardzko-Emiliańskiej, w: Dokumenty Rady Generalnej, Kraków 2005 nr 389 Rok LXXXVI kwiecień-czerwiec 2005, s. 83-84.

${ }^{17}$ Dekret Przełożonego Generalnego o ustanowieniu Delegatury obrzadku bizantyjsko-ukraińskiego w Ukrainie, w: Dokumenty Rady Generalnej, Kraków 2005 nr 389 Rok LXXXVI kwiecieńczerwiec 2005, s. 81-82.

18 Towarzystwo Salezjańskie i Córek Maryi Wspomożycielki. Elenko 2005-2006, Warszawa 2005, s. 156-157.

${ }^{19}$ Kapłan, który czuwał nad wykonywaniem praktyk religijnych i moralności w domu, był odpowiedzialnym za kleryków na danej placówce, ćwiczył ich w ceremoniach kościelnych, opiekował się towarzystwami religijnymi w zakładzie oraz czuwał nad zdrowiem współbraci i wychowanków. Ustawy i Regulaminy Towarzystwa św. Franciszka Salezego, Warszawa 1925, art. 54, 133, 186-190 (Reg.). 
Centralnej Inspektorii Serca Jezusowego w Turynie ${ }^{20}$. W ramach tzw. repatriacji większość salezjanów wyjechała z Wileńszczyzny. Ks. Bronisław pozostał, by służyć Polakom opieką duszpasterską, mimo że dom salezjański w Witanach zamknięto. Kolejne placówki ks. Bronisława były już parafiami polskimi. Od 1945 roku pracował jako wikariusz w Parafii Wniebowstąpienia Pana Jezusa w Ejszyszkach (dek. raduński). Tamtejszy proboszcz i dziekan, ks. Bolesław Moczulski, od wiosny 1947 roku był poważnie chory, stąd większość obowiązków duszpasterskich musiał wykonywać ks. Bronisław sam. Mimo młodego wieku odczuwał zmęczenie, głównie podczas wyjazdów furmanką do chorych i odprawianej kolędy po rozległej parafii liczącej ponad 10000 parafian, z której zaledwie kilka procent Polaków wyjechało do Polski. Od listopada 1947 roku przeszedł do Parafii Przemienienia Pańskiego w Porudomino (dek. turgielski). W parafii zorganizował chór parafialny i białe procesjanki. Z pomocą parafian wokół plebanii posadził drzewka owocowe, które miały stanowić pamiątkę po jego odejściu z Porudomino. W 1949 roku ks. Chodanionek wyjechał do Kiszyniowa, stolicy Mołdawskiej SRR. Tam pracował do śmierci w 1973 roku $^{21}$.

Ks. Tadeusz Hoppe. Po święceniach kapłańskich dn. 24 I 1943 roku w katedrze wileńskiej z rąk biskupa Mieczysława Reinysa, pracował kilka miesięcy w Wilnie przy kościele Opatrzności Bożej na ul. Dobrej Rady $22^{22}$. Od kwietnia tego roku ks. Hoppe podjął pracę duszpasterską w polskiej parafii Świętej Trójcy w Rudnikach, liczącej 4500 wiernych. Z Rudnik dojeżdżał także do parafii w Porudomino i Parafii św. Anny w Jaszunach. Jako proboszcz rudnicki pełnił także funkcję kapelana 6 Wileńskiej Brygady AK pod dowództwem (od III 1944) majora Franciszka Koprowskiego „Konara” w puszczy rudnickiej. W 1947 roku podjął obowiązki proboszcza w Solecznikach Wielkich, po wyjeździe do Polski ks. Józefa Stefanowicza. W Solecznikach ks. Hoppe podjął odbudowę kościoła, na fundamencie pozostałym po spalonej w lipcu 1944 roku drewnianej świątyni. Prace postępowały bardzo szybko, a to dzięki życzliwości i pomocy dyrektora miejscowego kołchozu, którego żona była katoliczką. Z inspiracji ówczesnych władz, w „dowód uznania” za trud w odbudowę spalonej świątyni, ks. Hoppe w 1949 roku został przeniesiony do parafii pielgrzymkowej w Kalwarii Wieleńskiej. Tymczasem w budującym się kościele w Solecznikach te same władze planowały otworzyć świetlicę ludową. Zanim przybył jego następca, ks. Paweł Bekisz, wierni dowiedziawszy się o planach komunistów, rozebrali budowlę, materiał przepadł, a kościół parafialny na tym miejscu nigdy nie stanął. Obecny kościół parafialny w Solecznikach to podstępem rozbudowywane etapami prezbiterium kaplicy cmentarnej rodziny Wagnerów. Przeniesiony do Kalwarii

${ }^{20} \mathrm{~W}$ czasie II wojny światowej domy salezjanów litewskich należały do Inspektorii Centralnej Serca Jezusowego w Turynie. Tak pozostało przez lata powojenne. A. Świda, Towarzystwo Salezjańskie. Rys historyczny, Kraków 1984, s. 190.

${ }^{21}$ Żurek, Jeńcy na wolności, s. 43-52.

${ }^{22} \mathrm{Na}$ ul. Dobrej Rady 22 w Wilnie salezjanie od 1924 roku prowadzili zakład wychowawczy - „Dom Serca Jezusowego”, a kilka lat później otworzyli tam Szkołę Rzemiosł. Ponadto obsługiwali niewielki sąsiedni kościół pw. Opatrzności Bożej. W. Żurek, Salezjańskie szkolnictwo ponadpodstawowe w Polsce 1900-1963, Lublin 1996, s. 188-191. 
Wileńskiej, ks. Hoppe oddawał się pracy duszpasterskiej jako kustosz sanktuarium pielgrzymkowego na całą Wileńszczyznę. Ostatnią placówką na terenie diecezji wileńskiej, w której ks. Hoppe duszpasterzował w latach 1954-1958, były Ławaryszki koło Wilna. Stąd na początku grudnia 1958 roku wyjechał do Odessy, gdzie pracował do śmierci ${ }^{23}$.

Ks. Stanisław Toporek. Po święceniach kapłańskich otrzymanych w 1934 roku w Krakowie skierowany został do pracy w archidiecezji wileńskiej. Jako neoprezbiter przejął kierownictwo Szkoły Rzemiosł w Dworcu Nowogródzkim. Od 1938 roku pracował w Wilnie na ul. Dobrej Rady 22, gdzie kierował Szkołą Rzemiosł i organizował warsztaty rzemieślnicze. W czasie tzw. repatriacji nie wyjechał z Wileńszczyzny. Po wojnie pracował wyłącznie w duszpasterstwie. Dojeżdżał z pomocą do Ejszyszek. Kolejne parafie to Rudniki z dojazdem do Jaszun (19481950), Porudomino, Stare Troki, Balingródek (1956-1962) i od jesieni 1962 roku rozpoczął proboszczowanie w Ławaryszkach, gdzie pracował do śmierci w 1977 roku. Pochowany został przy kościele św. Jana Chrzciciela w Ławaryszkach ${ }^{24}$.

Ze śmiercią ks. Toporka w 1977 roku odszedł ostatni salezjanin pochodzenia polskiego pracujący w Litewskiej SRR. Na przedwojennej Litwie Kowieńskiej pracowali salezjanie litewscy który po utworzeniu litewskiej republiki radzieckiej jurysdykcyjnie podlegali (od 1942) Centralnej Inspektorii Serca Jezusowego w Turynie. Schematyzm Generalny Zgromadzenia z 1947 roku wymienia na Litwie Kowieńskiej placówki salezjańskie: Kowno (parafia Świętej Trójcy od 1938), Kowno (rektor Seminarium Metropolitalnego - ks. Franciszek Pietraitis i pracownik koad. Vito Bübelis), Saldutiškis (parafia Przemienienia Pańskiego od 1939), Raseiniai (parafia Wniebowzięcia NMP ), Skiersnemune-Vytenai (Instytut św. Jana Bosko - aspirantat od 1934). Schematyzm ten podając te informacje w 1947 roku powołuje się na dane z 1942 roku. Wówczas wizytatoria litewska, z delegatem inspektora ks. Antonim Skeltysem, liczyła 23 salezjanów (księży - 9, braci - 12, kleryków - 2). Schematyzm Generalny z 1952 roku nie wymienia już salezjanów litewskich w Kownie (seminarium) i w Raseiniai (parafia). Od 1958 roku Schematyzm wymieniając domy litewskie: Kowno (parafia), Kowno (seminarium), Raseiniai, Saldutiski, Skiersnemune wymienia liczbę 16 salezjanów (księży -8 , braci -8$)$. W latach następnych ta liczba systematycznie się kurczyła gdy umierali kolejni współbracia (11 salezjanów w 1961 roku). Wreszcie Schematyzm z 1962 roku zaznacza, że wszystkie domy salezjańskie na Litwie są zlikwidowane i podaje już liczbę 14 salezjanów. Z tej liczby 6 kapłanów pracowało w duszpasterstwie. Pozostałych 8 braci zakonnych od lat powojennych pracowało zawodowo jako świeccy i praktykowali życie zakonne na miarę lokalnych możliwości w państwie rządzonym przez komunistyczne władze ${ }^{25}$.

W latach siedemdziesiątych ubiegłego stulecia z pomocą duszpasterską udawali się na Litwę polscy salezjanie. Wówczas przez tamtejsze władze było to tolerowane. Na prośbę Sióstr Benedyktynek na Zwierzyńcu w Wilnie przyjeżdżał

${ }^{23}$ Żurek, Jeńcy na wolności, s. 77-94.

${ }^{24}$ Żurek, Jeńcy na wolności, s. 210-222.

${ }^{25}$ Elenco Generale della Societa di S. Francesco di Sales 1947, vol. I, Torino 1947, s. 221-222; Elenco... 1958, vol. I s. 253. 
przynajmniej raz w roku, ks. Stanisław Szmidt, aby siostrom wygłosić rekolekcje i odprawić Mszę św. w domach kilku obłożnie chorych sióstr. Siostry wówczas żyły w rozproszeniu i mieszkały w prywatnych mieszkaniach. Kilka młodszych sióstr pracowało w zakładach państwowych. Rekolekcje u sióstr były okazją do odwiedzenia i pomocy ks. Stanisławowi Toporkowi w Ławaryszkach, ostatniemu salezjaninowi pracującemu na Litwie pod Wilnem i ks. Józefowi Obrębskiemu w Mejszagole, żyjącemu do dziś sędziwemu jubilatowi. Ponieważ ks. Toporek nie mógł się poruszać samodzielnie podwożono go z plebanii do kościoła samochodem, a Mszę św. sprawował siedząc. Któregoś roku przybył do Ławaryszek ks. Szmidt w sobotę przed odpustem parafialnym na św. Jana Chrzciciela. Ksiądz Toporek był tak słaby, że nie dał rady się ubrać do liturgii. W zastępstwie ks. Szmidt asystował przy kilku ślubach i ochrzcił kilkoro dzieci, w tym także przybyłych z Białoruskiej Republiki ${ }^{26}$.

Następnego dnia ks. Szmidt odprawił sumę odpustową ale i wygłosił kazanie, ponieważ ani sumista, ani kaznodzieja nie przyjechali. Ponieważ ks. Toporek obsługiwał także kościół w Kienie, czysto polskiej wiosce należącej do parafii w Ławaryszkach, ks. Szmidt odprawiał i tam kilka razy Mszę św. Taka pomoc duszpasterska byłaby wówczas nie do pomyślenia na terenie Białoruskiej Republiki, w Litewskiej Republice rygory były mniejsze. Ks. Szmidt jeździł na Litwę Radziecką od 1974 do stanu wojennego w Polsce, do 13 XII 1981 roku$^{27}$.

Do sióstr w Wilnie i na Ukraińską Republikę Radziecką jeździł także ks. Eugeniusz Cesarz (1925-) i ks. Józef Gregorkiewicz (1925-2006). Ten ostatni wyłącznie do Wilna.

Swoje rodzinne strony - Wileńszczyznę odwiedzał także i śpieszył z pomocą duchową dla wiernych tamtejszy rodak ks. Władysław Mikulewicz ${ }^{28}$, pochodzący z miejscowości Werki koło Kalwarii Wileńskiej, dzisiaj dzielnica Wilna. Po zmianie granic Polski, w ramach tzw. repatriacji, Władysław Mikulewicz przybył dnia 1 I 1946 roku do Polski. W następnym roku rozpoczął formację w Zgromadzeniu Salezjańskim i studia seminaryjne. Święcenia kapłańskie otrzymał 29 VI 1956 roku. W późniejszych latach nawet usiłował osiedlić się w Wilnie, ale bezskutecznie. Udało mu się to dopiero w kwietniu 1987 roku $^{29}$.

${ }^{26}$ Relacja ks. Stanisława Szmidta z 1 X 2006 roku - Łódź (zb. aut.).

${ }^{27}$ S. Szmidt, Rekolekcje białoruskie, „List Rodzinny”. Pismo religijno-społeczne, Nr 4 (67) 1997, s. 16.

${ }^{28}$ Ks. Mikulewicz Władysław, ur. 5 XII 1927 w Werkach. Syn Wacława i Felicji z Baniewiczów. Nowicjat salezjański rozpoczął w 1947 roku w Kopcu koło Częstochowy, gdzie złożył śluby czasowe 15 VIII 1948 roku. Po ukończeniu filozofii (1948-1950) i zdaniu matury w Krakowie, odbywał praktykę pedagogiczną w Twardogórze. W latach 1952-1956 studiował teologię w Oświęcimiu. Tam też złożył śluby wieczyste w 1953 roku i otrzymał święcenia kapłańskie w 1956 roku. Pracował w duszpasterstwie jako kapelan sióstr. Wraz z ks. Edwardem Bielawskim wyjechał ks. Władysław 24 V 1974 roku do Rzymu, a później po załatwieniu formalności wizowych do prokury misyjnej Belgii, następnie do Zairu (Kongo Demokratyczne) w Afryce. Po wypadku samochodowym został przewieziony do Belgii 11 X 1986 roku i stamtąd w kwietniu 1987 roku wrócił na Litwę do Wilna. Zmarł 6 X 2006 roku. W. Mikulewicz, S. Szmidt, Znad Wilii do Konga, Kraków 2001, s. 12--13.

${ }^{29}$ Mikulewicz, Szmidt, Znad Wilii do Konga, s. 13. 
Jego duch niespokojny „pchał” go na Wschód. Wyjeżdżał więc turystycznie na zaproszenie, pragnął odwiedzić rodzinne strony, zabrać tyle ile się dało dewocjonaliów i przedmiotów kultu, obrazków itp.

Pierwszy raz przybył na Wileńszczyznę pod koniec czerwca 1956 roku, będąc już diakonem. Żyła jeszcze wówczas w Wilnie jego mama Felicja i siostra Halina. Wiózł wówczas ze sobą korespondencję dla adresatów na Wileńszczyźnie. Niestety, w czasie rewizji funkcjonariusze KGB zabrali mu ją w całości. Jako neoprezbiter pojechał tam kolejny raz. W rodzinnej parafii Kalwarii Wileńskiej odprawił prymicyjną Mszę św. cichą, gdyż ówczesny proboszcz w Kalwarii obawiał się restrykcji władz. Odwiedził ks. Mikulewicz również podwileńskie Ławaryszki, gdzie proboszczem był ks. Tadeusz Hoppe. W Ławaryszkach zgotowano mu wspaniałą uroczystość prymicyjną. Kazanie wygłosił ksiądz proboszcz. Służyła duża grupa ministrantów, biel procesyjna, po Mszy św. była procesja teoforyczna ze sztandarami, błogosławieństwo księdza prymicjanta, uroczysty obiad i akademia. Dla obserwatora i uczestnika tych wspaniałych uroczystości prymicyjnych nic nie przypominało tamtych czasów represji Kościoła.

Po święceniach ks. Władysław urlopy najczęściej spędzał w byłym ZSRR. Tam starał się w miarę możliwości pomagać duszpasterzom na Białorusi i Ukrainie. I tam zrodziła się w jego sercu myśl wyjazdu na misje. Od tego czasu oczekiwał stosownej chwili aby te pragnienia urzeczywistnić.

Za czasów chruszczowowskich (Nikita Chruszczow zm. 1971) ks. Mikulewicz oszukał na pewien czas władzę radziecką. W 1969 roku udał się do Odessy nad Morze Czarne gdzie próbował rozpocząć pracę duszpasterską. Tam, na jemu tylko wiadomy sposób, zatrzymał się u rzekomej ciotki z myślą o pozostaniu na stałe, jeśli to będzie możliwe. Dla pewnego grona zaufanych odprawiał Mszę św. i głosił Słowo Boże. Czynił konspiracyjne wypady duszpasterskie w teren. Ks. Antoni Chomicki z Murafy dostarczał mu wino i hostie do sprawowania Mszy św. W Odessie udało mu się zatrzymać dwa lata. W przeciągu tego czasu cztery razy wyjeżdżał do Polski i wracał. Z pewnością po „zaopatrzenie”. Wytropił go jednak ks. Hoppe, który pewnego razu spotkał się potajemnie z ks. Mikulewiczem. Ks. Hoppe otrzymał wówczas od ks. Mikulewicza zapewnienie, żeby nie obawiał się go jako ewentualnego „konkurenta”, ks. Władysław zaręczał, że pragnie duszpasterzować na własną rękę i nie przysparzać nikomu kłopotów.

Niestety, KGB udaremniło jego starania o pozwolenie na pracę i zameldowanie. W 1971 roku został zatrzymany i uwięziony na dwa dni. Po przesłuchaniu został przymusowo odtransportowany do granicy Polski. Dwaj milicjanci odstawili ks. Władysława na dworzec kolejowy w Brześciu nad Bugiem, gdzie został przekazany polskim pogranicznikom ${ }^{30}$.

W Odessie ks. Mikulewicz przeszedł epidemię cholery. O oznaczonej godzinie na dźwięk syreny mieszkańcy spożywali lekarstwa. Na plaży odeskiej zebrano piasek do $20 \mathrm{~cm}$. Kiedy ks. Mikulewicz usłyszał decyzję o deportacji do Polski, powiedział: „Cholera mnie nie wypędziła z Odessy, a wy mnie wypędzacie”.

Oto inny epizod z życia ks. Mikulewicza i z jego pobytu na terenie Ukraińskiej

${ }^{30}$ Relacja ks. Władysława Mikulewicza z 10 IX 2003 roku - Odessa (zb. aut.). 
SRR. W 1970 roku ks. Chomicki, proboszcz w Murawie, zorganizował u siebie spotkanie księży, kolegów kursowych z Seminarium Duchownego w Łucku (święceni w 1935 roku w Łucku). Trudno dziś dociec jak w tamtych czasach władze komunistyczne wyraziły zgodę na spotkanie kursowe kapłanów. Ale ks. Chomickiemu udało się to załatwić legalnie i zorganizować zjazd. Z oczywistych względów rozmawiano po łacinie. Obiad był przygotowany w zakrystii. W tym czasie przebywał również w Murafie ks. Mikulewicz. Wszyscy uczestnicy zjazdu na zakończenie stanęli do wspólnego zdjęcia, także ks. Mikulewicz. Jednak w momencie utrwalania obrazu na kliszy fotograficznej ks. Mikulewicz zakrył twarz. Funkcjonariusze KGB wypytywali organizatora spotkania, kto był ten z zasłoniętą twarzą. Jakoś się obronił, lecz ks. Mikulewicz nie mógł w Murafie dłużej pozostać31.

Od 1971 roku wyjeżdżał turystycznie na Wschód ks. Franciszek Rosłan na zaproszenie. Udawał się do Porozowa za Wołkowyskiem i Solecznik Wielkich. Gdy inspektorem Prowincji św. Wojciecha został w 1986 roku ks. Stanisław Skopiak, jego kolega kursowy z seminarium, ks. Franciszek sądził, że uda mu się wreszcie wyjechać do pracy misyjnej na Wschodzie. Niestety, decyzja przełożonego była odmowna. Dopiero kiedy zaniemógł zdrowotnie ks. Antoni Rafałko w Oszmianie na Białorusi, ks. Franciszek otrzymał polecenie udania się do Oszmiany. Miał się tam stawić na najbliższą niedzielę. Przybył tam już w środę ${ }^{32}$.

\section{b) Salezjanie na Litwie}

Z państw powstałych na bazie republik radzieckich liczebnie najmniej placówek mają dzisiaj salezjanie na Litwie - 2. Dwie placówki i dwie wspólnoty zakonne: w Kownie i Wilnie, obydwie pw. św. Jana Bosko.

Parafia św. Jana Bosko w Wilnie. Salezjański dom zakonny z parafią położony jest $\mathrm{w}$ nowej dzielnicy miasta. Liczy ona obecnie ponad 45 tys. wiernych. Około $70 \%$ to Litwini, reszta osoby polskiego pochodzenia. Nabożeństwa odprawiane są w dwóch językach: polskim i litewskim. Placówka redaguje własną gazetkę. Pięknie prowadzona jest praca z dziećmi i młodzieżą: ministranci, schola, spotkania świetlicowe, chór polski i litewski. Parafię obsługuje 4 kapłanów: dwóch Polaków, którzy obecnie posiadają obywatelstwo litewskie, jeden Włoch i jeden Litwin. Do pracy duszpasterskiej w Wilnie przygotowuje się językowo dwóch Wietnamczyków ${ }^{33}$. Przy parafii salezjanie zorganizowali Ośrodek Młodzieżowy.

Ks. Izydor Sadowski ${ }^{34}$ położył duże zasługi w zdobywaniu funduszy (w tym celu kilkakrotnie wyjeżdżał do Kanady) i budowaniu plebanii, kaplicy i kościoła pw. św. Jana Bosko w Wilnie ${ }^{35}$.

\footnotetext{
${ }^{31}$ Relacja ks. Władysława Mikulewicza z 10 IX 2003 roku - Odessa (zb. aut.).

${ }^{32}$ Relacja ks. Franciszka Rosłana z 29 VIII 2005 roku - Przemyślany (zb. aut.).

${ }^{33}$ Ks. Bernard Kaliński do ks. W. Żurka z 5 X 2006 roku - Lutomiersk (zb. aut.).

${ }^{34}$ Lietuviř saleziečiř istorija, red. K. Juknevičius, Kaunas 2000, s. 326-327.

${ }^{35} \mathrm{~W}$ wyniku nieporozumień opuścił Litwę. Jakiś czas przebywał w salezjańskiej parafii
} 
Na Kapitule Okręgu Wschodniego w 2004 roku odbywającej się w Petersburgu salezjanie litewscy zgłosili projekt włączenia domów litewskich do inspektorii któregoś z państw Unii Europejskiej, z równoczesnym wyłączeniem ich z Okręgu. $\mathrm{Na}$ wspomnianej Kapitule przeprowadzono głosowanie-sondaż, którego wynik okazał się korzystny dla petentów litewskich. Powyższą sprawę przesłał do rozstrzygnięcia Radzie Generalnej w Rzymie przełożony Okręgu Europa Wschodnia, ks. Henryk Boguszewski.

Oceniwszy przedstawione motywacje związane z przystąpieniem Litwy do Unii Europejskiej, a także różnice kulturowe, społeczne i polityczne Litwy względem innych krajów byłego Związku Radzieckiego, jak również trudności w komunikacji z innymi krajami Okręgu oraz biorąc pod uwagę, że już w przeszłości Litwa złączona była $\mathrm{z}$ jedną z inspektorii włoskich, po uzyskaniu pozytywnej opinii prowincjała Inspektorii Lombardzko-Emiliańskiej z siedzibą w Mediolanie, Rada Generalna dnia 12 I 2005 roku (zgodnie z art. 132 Konstytucji Zgromadzenia) przychyliła się do prośby salezjanów litewskich. Na tej podstawie Przełożony Generalny Zgromadzenia postanowił, aby dwa domy salezjańskie na Litwie: Kowno - pw. św. Jana Bosko i Wilno - pw. św. Jana Bosko, wraz z dziełami i współbraćmi wyłączone zostały z Okręgu Wschodniego Niepokalanego Poczęcia NMP i przyłączone z dniem 15 VIII 2005 roku do Inspektorii św. Karola Boromeusza z siedzibą w Mediolanie (Inspektoria Lombardzko-Emiliańska) ${ }^{36}$.

W październiku 2006 roku inspektor z Mediolanu, do którego inspektorii należy Litwa, poprosił polskich salezjanów o wsparcie pracy salezjanów na Litwie. Chodzi o pracę duszpasterską zwłaszcza wśród Polaków a potem również i Litwinów. Inspektor prowincji św. Jacka z Krakowa, ks. Marek Chrzan jest otwarty na tę prośbę i skierował ten apel do współbraci prowincji, aby chętni zgłaszali się z myślą o wyjeździe na Litwę ${ }^{37}$.

\section{BIALORUSKA SOCJALISTYCZNA REPUBLIKA RADZIECKA - BIALORUŚ}

\section{a) Czasy republiki radzieckiej}

$\mathrm{Na}$ terenach obecnej Białorusi, a do 1939 roku na wschodnich rubieżach II Rzeczypospolitej, należących do archidiecezji wileńskiej i diecezji pińskiej, które po 1945 roku znalazły się w granicach ZSRR, z około 360 parafii i znacz-

w Suwałkach. Kilka miesięcy temu wyjechał do Kanady. Ks. Bernard Kaliński do ks. W. Żurka z 5 X 2006 roku - Lutomiersk (zb. aut.).

${ }^{36}$ Dekret Przełożonego Generalnego o przyłączeniu domów salezjańskich na Litwie do Inspektorii Lombardzko-Emiliańskiej, w: Dokumenty Rady Generalnej, Kraków 2005 nr 389 Rok LXXXVI kwiecień-czerwiec 2005, s. 83-84.

${ }^{37}$ Komunikaty i informacje, w: Jesienna zaduma o świętości. List okólny inspektora prowincji św. Jacka w Krakowie do salezjanów prowincji krakowskiej z 1 XI 2006 roku L0 3 - 2006/2007 Kraków. 
nie większej liczby kościołów pozostało jedynie $90^{38}$. Reszta świątyń została zamknięta, zdewastowana, a budowle sakralne przeznaczono na cele nie kultowe. Komunistyczne ustawodawstwo Białoruskiej Republiki zabraniało dzieciom i młodzieży niepełnoletniej uczestnictwa w nabożeństwach kościelnych.

Do tego co już zostało przedstawione wcześniej na temat polityki kościelnej komunistycznej władzy radzieckiej, można najogólniej dodać, że niszczono wszelkie przejawy życia religijnego. Niszczono tradycje katolickie, akcentując takie „święta” jak: rocznica rewolucji październikowej, rocznica zakończenia II wojny światowej, 1 Maja, Nowy Rok, Święto Kobiet (8 III) oraz Święto Kupały (24 VI). Na szczególną uwagę zasługuje dewastacja cmentarzy w tamtych czasach. Wypuszczano z domów dziecka wychowanków, którzy łamali nawet żeliwne krzyże z niezwykłą pasją ${ }^{39}$.

Do połowy lat siedemdziesiątych ubiegłego stulecia zadaniem nauczycieli szkolnych było pilnować dróg wiodących do kościoła. Gdy rodzice prowadzili dzieci do kościoła, nauczyciele notowali ich nazwiska, a na drugi dzień na apelu szkolnym dzieci były wyśmiewane i maltretowane psychicznie.

Mimo różnorodnych utrudnień, zarówno siostry zakonne jak i księża przygotowywali młodych do I Komunii świętej. Odbywało się to w warunkach konspiracyjnych, najczęściej poza plebanią. Dzieci zbierały się i rozchodziły pojedynczo, by nie wzbudzić podejrzeń. Ks. Józef Obrębski z Mejszagoły koło Wilna pokazywał kiedyś taką „salkę katechetyczną". W krzakach oddalonych od plebanii zbierały się dzieci na katechezę. Mówił on, że każdego roku udało mu się przygotować w ten sposób 20-30 dzieci. Dzieciom tłumaczył, że on nie prowadzi katechizacji tylko ich rodzice, gdyż to jest dozwolone, natomiast ksiądz jedynie odpytuje. To również było dozwolone, natomiast nauczanie przez katechetę było zabronione $^{40}$.

Młodsze pokolenie wyrosłe w czasach komunistycznych nie rozumiało najbardziej podstawowych spraw związanych z życiem Kościoła, takich jak: Boże Ciało, procesja na cmentarz w święto Wszystkich Świętych, uroczysta I Komunia św., pogrzeb z udziałem kapłana, rezurekcja.

Po odmowie wyjazdu w ramach tzw. repatriacji Polaków z terenu Białoruskiej Socjalistycznej Republiki Radzieckiej, pięciu salezjanów pozostało tam, głównie dla opieki duszpasterskiej nad pozostałymi. Należeli do tej liczby księża: Michał Bulowski, Kazimierz Grzegorczyk, Jan Tokarski, Jan Wielkiewicz, Ludwik Witkowski ${ }^{41}$.

${ }^{38} \mathrm{Na}$ tej części Białorusi, która w okresie międzywojennym należała do ZSRR, nie pozostał czynny ani jeden kościół katolicki i nie pracował żaden kapłan.

${ }^{39}$ Ks. Bernard Kaliński do ks. W. Żurka z 5 X 2006 roku - Lutomiersk (zb. aut.).

${ }^{40}$ Ks. Bernard Kaliński do ks. W. Żurka z 5 X 2006 roku - Lutomiersk (zb. aut.).

${ }^{41}$ Spis ludności ZSRR przeprowadzony w 1959 roku, gdy zakończyła się już ekspatriacja, określił liczbę obywateli narodowości polskiej w Białoruskiej SRR liczbą 538,1 tys. Spis 30 lat później już tylko 417,7 tys. ludności polskiej. Ostatni spis w 1999 roku wykazał, że liczba osób deklarujących przynależność do narodowości polskiej wynosiła 396 tys. (3,2\%) mieszkańców Białorusi. Poszczególni autorowie podają dość różne i rozbieżne cyfry na ten temat. Faktyczne ustalenie liczby ludności pochodzenia polskiego było i jest $\mathrm{z}$ wielu przyczyn bardzo trudne. R. 
Na pożegnanie ostatnich współbraci zmuszonych przez miejscowych Rusinów do wyjazdu z Reginowa (parafia Nowopolna k. Baranowicz, diec. pińska), ks. Michał Bulowski ${ }^{42}$ przybył w przebraniu białoruskiego mużyka (chłopa) przepasanego powrósłem słomy, którego nie rozpoznali nawet współbracia salezjanie. Od momentu inwazji Armii Czerwonej na Polskę we wrześniu 1939 roku ks. Michał zamieszkał prywatnie u ludzi w Reginowie. Odczuwając dolegliwości zdrowotne, postanowił leczyć się ziołami. Po zdobyciu pewnego doświadczenia, pomagał także tamtejszym wieśniakom w leczeniu ich chorób. W ten sposób zdobył u nich autorytet moralny i uznanie, a darząc ich zaufaniem, resztę życia po 1945 roku postanowił spędzić na terenach, gdzie pracował od 1936 roku - w Reginowie.

Przez jakiś czas pracował ks. Michał w parafii Matki Bożej Anielskiej w Leśnej k. Baranowicz, w diecezji pińskiej, liczącej przed II wojną ok. 1500 wiernych. Kościół Opieki Św. Józefa w Rubieżewiczach (dekanat Stołpce) objął prawdopodobnie w 1952 roku. Wówczas był już po sześćdziesiątce. Odczuwał dolegliwości zdrowotne, głównie dokuczała mu cukrzyca. Obowiązki duszpasterskie wypełniał gorliwie. Nie znosił przepychu, lubił skromność. Głosił budujące kazania, urozmaicane anegdotami z codziennego życia, które tak ujmowały słuchaczy, że słuchając ich - „trzeba się było brać za brzuch”, ratując się przed śmiechem, wspominają do dziś parafianie. Od 1956 roku los ks. Michała pozostaje nieznany. $\mathrm{Na}$ temat czasu, miejsca, okoliczności śmierci i miejsca pochówku księdza krąży kilka wersji, do dziś nie wyjaśnionych ${ }^{43}$.

Ks. Kazimierz Ryszard Grzegorczyk, po ukończeniu studiów teologicznych w Wilnie, święcenia kapłańskie otrzymał 17 XII 1941 roku. W 1944 roku został skierowany na administratora parafii Trójcy Przenajświętszej w Dokszycach, dek. Głębokie, w arch. wileńskiej. Pracując tam odmówił wyjazdu w ramach tzw.

Dzwonkowski, O. Gorbaniuk, J. Gorbaniuk, Postawy katolików obrzadku łacińskiego na Białorusi wobec języka polskiego, Lublin 2004, s. 7.

${ }^{42}$ Ks. Bulowski Michał, syn Franciszka i Felicyty zd. Dudek, ur. 3 IX 1891 roku w Chwałowicach, ochrzczony 3 IX 1891 roku w Pniowie. Gimnazjum kończył w Oświęcimiu w latach 1905-1910, nowicjat 1910/1911 w Radnej (Słowenia), święcenia kapłańskie 22 XII 1918 roku w Gualdo Tadino. Pracował na placówkach parafialnych i wychowawczych w Krakowie, Przemyślu-Zasanie, Wilnie, Ciechanowie, Płocku. Od 1936 roku pełnił obowiązki spowiednika w Reginowie. Tam przeżył II wojnę światową. Żurek, Jeńcy na wolności, s. 15.

${ }^{43}$ Najbliższy sąsiad, ks. Jan Wielkiewicz z Zdzięcioła pisał 30 XI1956 roku do inspektora Prowincji św. St. Kostki, ks. Stanisława Rokity w Warszawie: „Zginął w tragicznych warunkach”. Koadiutor Jan Osomański w krótkiej biografii do Nekrologu salezjańskiego zanotował: „Lecz 17 lat to za dużo nawet wśród przyjaciół. Z czasem jego stosunki z wieśniakami tak niebezpiecznie zaczęły się plątać, że postanowił uciec. Ale zadraśnięta ambicja i prostacka chytrość osaczyła go w matni. Z jednej z wycieczek apostolskich w miesiącu wrześniu 1956 roku z której zamierzał nie wracać, nie wrócił istotnie”. Nekrolog salezjański podaje krótko: „... wywieziony został z Reginowa, nie wiadomo gdzie i kiedy zginął, najprawdopodobniej we wrześniu 1956 roku”. Ks. Władysław Mikulewicz z Wilna konstatuje: „Jakaś kobieta wywiozła ks. Bulowskiego z Reginowa, gdzie ostatnio pracował, do Kazachstanu. Miał mieć złoto. By je przejąć, ks. Bulowski został porwany”. Adam Hlebowicz, zajmujący się tematyką Kościoła na Wschodzie podaje: „Zmarł w Celinogrodzie - w Kazachstanie - lub w Moskwie 30 IX 1956 roku”. Anonimowa notatka podaje: „Zginął z rąk przyziemnych wykolejeńców we wrześniu 1956 roku”. Cyt. za Żurek, Jeńcy na wolności, s.26-27. 
repatriacji do Polski Ludowej. Po krótkotrwałej pracy w parafii w Głębokim, w grudniu 1945 roku przeszedł ks. Kazimierz do parafii św. Andrzeja Apostoła w Łyntupach, dek. Święciany. Zamieszkał u parafian do momentu wybudowania plebanii w 1947 roku. Parafię sześciotysięczną w Łyntupach przejął po ks. Józefie Pakalnisie (proboszcz od 1920 roku), który od 1935 roku już jako emeryt mieszkał i pracował nadal w Łyntupach († 30 XII 1946). Kościół był zniszczony działaniami wojennymi i zaniedbany, okna zasłonięte matami. Ks. Grzegorczyk podjął prace nad jego odnowieniem i pomalowaniem. Wiele prac wykonywał własnymi rękami. Czasy nie były łatwe. Dzieci i młodzież miały wówczas zakaz uczęszczania do kościoła. Nie było ministrantów. Jedynie starsi mężczyźni służyli do Mszy św. Jak każdy kapłan w tamtych czasach, ks. Kazimierz żył w ustawicznym strachu. Dzięki milicjantowi miejscowemu (Rosjaninowi), który informował „przez kogoś" o planowanym aresztowaniu proboszcza, ks. Kazimierz nie tylko nie nocował na plebanii, ale mieszkając u ludzi, zmieniał często miejsce tymczasowego zamieszkania. Odpowiednie służby państwowe nachodziły go i prawdopodobnie był bity. Odczuwał coraz bardziej bóle głowy, lęki, utratę pamięci, dolegliwości serca ${ }^{44}$.

W piątek 19 XII 1959 roku nie przybył na poranną Mszę św. Wierni czekali niecierpliwie w kościele. Wreszcie zdecydowali pójść na plebanię i sprawdzić, co się wydarzyło. Zastali księdza w pokoju sypialnym nieżywego. Leżał w łóżku w naturalnej pozycji z rękami na kołdrze, plecy i piersi miał sine, radio zakupione dzień wcześniej grało bardzo głośno. Milicja nie zarządziła sekcji zwłok. „Jeden czarny mniej" - brzmiała odpowiedź. Gdy przybył ksiądz dziekan ze Święcian, mieszkanie zmarłego było doszczętnie okradzione. Dziekan nie znalazł kompletnie nic: notatek, pieniędzy, książki z intencjami mszalnymi, nawet jego garderoby. Potrzebną bieliznę na ubranie zmarłego ks. Kazimierza dał organista Jan Korejło. Pracujący po sąsiedzku salezjanie na temat jego śmierci przekazali relację, że tej nocy - 18 grudnia poproszono księdza do chorego z posługą sakramentalną. $\mathrm{Na}$ plebanię już nie wrócił. Zmarł na skutek pobicia ${ }^{45}$.

Po święceniach kapłańskich 16 III 1941 roku w Wilnie z rąk metropolity wileńskiego, abpa Romualda Jałbrzykowskiego, ks. Jan Franciszek Tokarski dwa miesiące pracował w kościele św. Stefana w Wilnie. Od połowy maja 1941 roku metropolita skierował go do Horodzieja k. Nieświeża, w diec. pińskiej. W 1944 roku przybył do parafii Narodzenia NMP w Dubrowej, dek. Mołodeczno w arch. wileńskiej. Obsługiwał także sąsiednią parafię św. Józefa w Pierszajach oraz kościół Matki Bożej Różańcowej i Ducha Swiętego w Rakowie k. Mińska. Mieszkał w obszernej plebanii w Dubrowej. Tam dnia 16 VI 1948 roku został aresztowany. Skazany na 10 lat więzienia, wyrok odbywał w Autonomicznej Rosyjskiej Republice Komi, w łagrze Inta, między miastami Pieczora a Workuta, a od 1949 roku w miejscowości Obis. W 1951 roku ks. Jan powrócił do Mołodeczna na ponowną rozprawę, na której otrzymał wyrok: karę śmierci, zamienioną na 25 lat łagrów. Zarzut brzmiał: ,,uparty w wierze, uczył dzieci religii, a nie mogąc przeko-

\footnotetext{
${ }^{44}$ Żurek, Jeńcy na wolności, s. 62-68.

${ }^{45}$ Tamże, s. 69-70.
} 
nać, przyciągał cukierkami”. Wywieziono go do obozu pracy w Republice Komi. Tam po pół roku udało mu się odprawić Mszę św. Kielich zastąpił kubek, wino z rodzynek i hostię otrzymał od Bronisławy Ejsmont z Krasnego w paczce żywnościowej. Potajemnie spełniał funkcje kapłańskie wśród łagierników. Odsiedział 6 lat i 8 miesięcy. Zwolniony w 1954 roku na mocy amnestii dla skazanych na 25 lat powrócił do ks. Józefa Marsängera (jezuita) w Krasnem, a po trzech latach starań i otrzymaniu tzw. sprawki osiadł na stałe w Rakowie k. Mińska, z możliwością sprawowania funkcji kapłańskich. Wielokrotnie odbierano mu „sprawkę”, wówczas posługi spełniał prywatnie, na możliwe sposoby. W Rakowie przeżył dwukrotnie kradzież w kaplicy połączoną z profanacją Najświętszego Sakramentu ${ }^{46}$.

$\mathrm{Z}$ biegiem lat pojawiały się dolegliwości, a organizm zżerany cukrzycą tracił siły. Zmarł 15 XII 1974 roku w szpitalu w Mińsku. Liturgię pogrzebową odprawił współtowarzysz z łagru, a wówczas proboszcz z Rubieżewicz i przyjaciel zmarłego, ks. Piotr Pupin (1912-1978).

Po aresztowaniu w listopadzie 1939 roku i wywiezieniu na Sybir dyrektora salezjańskiego Zakładu Świętego Józefa i proboszcza parafii Bożego Ciała w Dworcu (woj. nowogródzkie), ks. Jana Kapusty ${ }^{47}$, w Dworcu pozostali dwaj salezjanie: ks. Ludwik Witkowski i ks. Jan Wielkiewicz. Wypędzeni przez Sowietów z budynków kościelnych, mieszkali u parafian. Ks. Wielkiewicz wkrótce przeszedł na parafię do sąsiedniej Nowojelni, a od kwietnia 1946 roku po śmierci proboszcza i dziekana ks. Józefa Sawickiego (1883-1946) w Zdzięciole, podjął tam obowiązki proboszcza i dziekana w parafii Wniebowzięcia NMP na osieroconej parafii. Po jego odejściu z Nowojelni tamtejszy kościół drewniany zamieniono na kino i dom sportu. W Zdzięciole mieszkał w bardzo skromnych warunkach, nie oszczędzał zdrowia, pracował ponad siły. Dla wzmocnienia sił przybył w marcu 1968 roku do Polski. Leczony był w szpitalu w Łodzi. Poddany został intensywnej kuracji. Lekarze zalecali ostrożność, nie przeciążanie organizmu. Gdy poczuł się lepiej, zdecydował o powrocie na Białoruś. Nie posłuchał rad lekarzy, rodziny, współbraci i przełożonych. Na początku czerwca tego roku wyjechał do „swoich”. Podjął na miejscu dotychczasowe obowiązki. Oprócz cukrzycy, niedomogów serca i nerek, doszedł skurcz przewodu pokarmowego, który zamykał stopniowo dostęp do żołądka. Konieczna była operacja. Wreszcie skurcz zamknął otwór przewodu pokarmowego i nastąpiła śmierć 12 II 1969 roku. Pochowany został na cmentarzu parafialnym w Zdzięciole ${ }^{48}$.

Pracujący od 1931 roku w Zakładzie św. Józefa w Dworcu ks. Ludwik Witkowski, od 1934 roku przebywał tam bez urzędu. Na skutek dolegliwości zdrowotnych, głównie skrupułów, nie spełniał funkcji kapłańskich (także nie odprawiał Mszy św.). Po zajęciu we wrześniu 1939 roku zakładu przez Sowietów ks. Witkowski zmuszony był zamieszkać u ludzi. Zewnętrznie wyglądał na mocno zaniedbanego. Po wyjeździe z Dworca większości współbraci do Polski centralnej już w 1940 roku, 1944 i 1946 roku, pozostał tam jedynie ks. Witkowski i ks.

46 Tamże, s. 181-190.

${ }^{47}$ Elenco Generale della Societa di S. Francesco di Sales 1947, vol. 1, Torino 1947, s. 221-222; Elenco 1958, vol. I s. 253.

48 Żurek, Jeńcy na wolności, s. 230-233. 
Wacław Rybicki, tamtejszy spowiednik, który duszpasterzował tam do końca wojny. W tych trudnych pod każdym względem warunkach wojennych ks. Ludwik poczuł się potrzebny. Mając zdolności malarskie malował mieszkańcom obrazy religijne. Zachęcony przez ks. Juliana Rykałę i z jego pomocą przyswoił sobie modlitwy przy sprawowaniu sakramentów świętych (pokuty) i rozpoczął sprawować czynności kapłańskie, w tym i odprawianie Mszy św. Ksiądz Ludwik duszpasterzował w Dworcu do swej śmierci w 1952 roku. Tam właściwie spędził prawie całe życie kapłańskie (wyświęcony w 1928 roku w Wilnie). Mimo że niedomagał psychicznie, choroba nie była uciążliwa dla otoczenia, które okazywało księdzu wiele wyrozumienia. Do ostatniego dnia sprawował funkcje kapłańskie. Zmarł w Dzień Zaduszny 1952 roku na skutek krwotoku. Pochowany został na cmentarzu parafialnym w Dworcu obok zmarłych wcześniej dwóch współbraci-koadiutorów. Wkrótce po jego śmierci kościół parafialny w Dworcu został zamknięty przez komunistów, gdyż ludzie nie mogli płacić wysokich podatków ${ }^{49}$.

Na początku lat 60. ubiegłego stulecia przybył legalnie do Polski z Białoruskiej SRR Józef Zaniewski ${ }^{50}$. Uzyskał prawo pobytu w Polsce dzięki znajomości i zabiegom ks. Franciszka Pytla (1913-1984), ówczesnego dyrektora domu nowicjackiego w Czerwińsku k. Warszawy (pełnił także funkcję wiceprezesa Polonii Amerykańskiej). Józef w sercu nosił pragnienie poświęcenia się na służbę Bogu, a teraz Opatrzność skierowała go na szlak powołania salezjańskiego. Po odbyciu formacji początkowej w nowicjacie w Czerwińsku w 1964/1965 i złożeniu tam ślubów zakonnych realizował swoje powołanie jako salezjanin-koadiutor, czyli brat zakonny. Po złożonych ślubach spełniał różne funkcje: kościelnego, ogrodnika a głównie kierowcy od 1972 roku. Od pewnego momentu, trudno to czasowo określić, rozpoczął się dla Józefa okres „cichego" przygotowywania formacyjnego i intelektualnego do kapłaństwa, by go następnie jako salezjanina ,przerzucić” z powrotem na teren Białoruskiej Republiki, do pracy duszpsterskiej.

Całe to przedsięwzięcie było ogromnie ryzykowne i niezwykle odważne dla Józefa, którego czekał trud zdobycia odpowiedniej wiedzy teologicznej w bardzo niekonwencjonalny sposób. Uczył się prywatnie, głównie łącząc naukę z pracą. Jako kierowca ówczesnego inspektora, ks. Stanisława Styrny, także w czasie podróży, kiedy prowadził samochód, słuchał jego wykładów seminaryjnych. Przez dwa lata nietypowy „,seminarzysta” zdobywał odpowiednie kwalifikacje z nauk teologicznych. Wreszcie dnia 7 VIII 1978 roku potajemnie został wyświęcony na kapłana przez ówczesnego sekretarza episkopatu bpa Bronisława Dąbrowskiego w jego prywatnej kaplicy. Po święceniach pozostała otwarta sprawa jego powrotu na Białoruś, już jako księdza. Posiadając obywatelstwo radzieckie, w krótkim czasie wyjechał do Grodna i podjął pracę w browarze. Wieczorami ostrożnie udzielał

${ }^{49}$ Tamże, s. 287-290.

${ }^{50}$ Zaniewski Józef, ur. się 10 V 1941 roku w Zaniewiczach k. Grodna w głęboko religijnej rodzinie. Szkołę Podstawową ukończył w Litwinkach, maturę w wieczorowym Liceum Ogrodniczym w Grodnie. Stosunkowo wcześnie zmarli mu rodzice: Jan i Maria zd. Zaniewska. Józef, jako najstarszy z rodzeństwa, przejął odpowiedzialność za nie, zastępując ojca. Życie nauczyło go wielu praktycznych uzdolnień. Był przysłowiową „złotą rączką”. W 1963 roku przyjechał do Polski. Weder, Znaki nadziei, s. 46-50. 
się w kościele pobernardyńskim w Grodnie. Aż pewnego dnia jeden z robotników browaru rozpoznał go mówiąc: „A ja się wczoraj u was spowiadałem!”. Był to dla ks. Józefa sygnał alarmowy, iż musi opuścić Grodno, gdzie został zdemaskowany. Po ujawnieniu, że jest kapłanem, był wielokrotnie wzywany na przesłuchania. Po kilku miesiącach został mianowany proboszczem parafii w Gierwiatach na Białorusi. Tam pracował kilka lat nagabywany często przez ówczesne władze sowieckie ${ }^{51}$.

\section{b) Republika Białorusi}

Odwiedziny we wrześniu 1988 roku Prymasa Polski, kard. Józefa Glempa w Grodnie, Lidzie, Nowogródku i Pińsku i sprawowana w pińskiej katedrze uroczysta liturgia, w symboliczny sposób zwiastowały zasadnicze zmiany w dotychczasowej sytuacji Kościoła katolickiego w Białoruskiej SRR. Nowe czasy zapoczątkowała w 25 VII 1989 roku nominacja administratora apostolskiego dla katolików na Białorusi - ks. dra Tadeusza Kondrusiewicza z Grodna. Dwa lata później Jan Paweł II utworzył administrację kościelną na Białorusi, która proklamowała swoją niepodległość państwową w 1991 roku. Erygowana została archidiecezja mińsko-mohylewska (obłasti: mińska, mohylewska, witebska) z ordynariuszem i pierwszym biskupem ks. prał. Kazimierzem Świątkiem, dotychczasowym wikariuszem generalnym diecezji pińskiej w Związku Sowieckim. Powstała jednocześnie diecezja grodzieńska, której ordynariuszem został dotychczasowy proboszcz parafii Świętego Ducha w Wilnie, ks. Aleksander Kaszkiewiecz. Diecezja pińska otrzymała nowe granice i obecnie obejmuje obłasti: brzeską i homelską. Kolejna diecezja witebska na Białorusi erygowana została w 13 X 1999 roku z ordynariuszem biskupem Władysławem Blinem, dotychczasowym proboszczem w Mohylewie.

Obecnie podział administracyjny Kościoła katolickiego na Białorusi to cztery diecezje należące do metropolii mińsko-mohylewskiej: archidiecezja mińsko-mohylewska (administrator apostolski - bp Antoni Dziemianko), diecezja grodzieńska (biskup diecezjalny - Aleksander Kaszkiewicz), diecezja pińska (administrator apostolski - kard. Kazimierz Świątek), diecezja witebska (biskup diecezjalny - Władysław Blin) ${ }^{52}$.

Dnia 11 XI 1992 roku zostały nawiązane stosunki dyplomatyczne pomiędzy Stolicą Apostolską a Republiką Białorusi. Papież Jan Paweł II bullą „Quontam tandem” założył kanonicznie Nuncjaturę Apostolską na Białorusi. Pierwszym nuncjuszem został abp Gabriel Montalvo (1993-1994) - Kolumbijczyk; następnie abp Agostino Marketto (1994-1996) - Włoch; abp Dominik Gruszowski (1996-

${ }^{51}$ Weder, Znaki nadziei, s. 47-48; Ks. Bernard Kaliński do ks. W. Żurka z 5 X 2006 roku Lutomiersk (zb. aut.).

${ }^{52}$ R. Dzwonkowski, Pierwszy arcybiskup Białorusi ks. prał. Kazimierz Światek, „Królowa Apostołów", s. 12-13; www.catholic.by. 
-2001) - Słowak; bp Iwan Jurkowič (2001-2004) - Słoweniec; abp Martin Vidovič $(\operatorname{od} 2004)^{53}$.

Alumni z Białorusi kształcą się w dwu seminariach duchownych: Międzydiecezjalnym Wyższym Seminarium Duchownym św. Tomasza w Pińsku oraz w Wyższym Seminarium Duchownym w Grodnie. Kandydaci do kapłaństwa pochodzący z tamtejszych wspólnot zakonnych kształcą się także w swoich seminariach duchownych w Polsce i w innych krajach Europy.

Przyszłych katechetów kształcą dwa ośrodki naukowe: Kolegium Katechetyczne w Baranowiczach oraz Instytut Katechetyczny w Grodnie.

W 1999 roku została utworzona Konferencja Biskupów Katolickich na Białorusi. Zgromadzenie Konstytutywne Konferencji odbyło się 11 II 1999 roku. Pierwszym przewodniczącym Konferencji został wybrany kard. Kazimierz Świątek. Obecnie przewodniczącym Konferencji jest bp Aleksander Kaszkiewicz, wiceprzewodniczącym Władysław Blin, sekretarzem generalnym bp Antoni Dziemianko. W skład Konferencji wchodzą: kard. Świątek, arcybiskup metropolita mińsko-mohylewski na emeryturze i administrator apostolski diecezji pińskiej oraz Kazimierz Wielkosielec, biskup pomocniczy diecezji pińskiej ${ }^{54}$.

Równinny krajobraz Białorusi, z zachowaną szachownicą pól, przeplatany obszarami leśnymi ukazuje bogatą przyrodę kraju, która w swym bogactwie przez dziesiątki lat powojennych pozbawiona była oznak religijnych: m. in. krzyży, kapliczek przy trasach komunikacyjnych czy krzyżówkach dróg. Po nastaniu wolności w wyznawaniu wiary w sercach ludzkich rodzi się potrzeba wizualnej „sakralizacji” tej ziemi. Objawia się to m. in. poprzez ustawianie krzyży katolickich i prawosławnych na granicach wiosek i miast lub na skrzyżowaniach dróg. Ta przyroda i ziemia wygląda teraz inaczej, jest bardziej przyjazna człowiekowi wierzącemu ${ }^{55}$.

W roku 1989 na Białorusi stan duchowieństwa przedstawiał się katastrofalnie. Wszystkich kapłanów pracowało 63 . Większość w wieku podeszłym lub starszym, schorowanych, znerwicowanych, wielu po odsiedzeniu wyroku w więzieniach lub na zsyłkach.

Do pionierskiej grupy salezjanów z Polski, którzy przybyli do Białoruskiej SRR w 1989 roku byli: ks. Kazimierz Szoka, ks. Wojciech Biśkiewicz, ks. Henryk Boguszewski, ks. Bernard Kaliński, ks. Edward Mackiewicz ${ }^{56}$, ks. Henryk Kulaszewicz, ks. Antoni Rafałko, ks. Zdzisław Pikuła - wszyscy z Inspektorii św. Stanisława Kostki. W następnych latach przybyli: ks. Józef Bogusz, ks. Krzysztof Cabała, ks. Wiesław Dąbrowski, ks. Michał Kłoda, ks. Stanisław Ługowski, ks.

${ }^{53}$ Abp Martin Vidovič, dotychczasowy oficjał Sekretariatu Stanu Stolicy Apostolskiej. Od 1994 roku pracował w służbie Stolicy Apostolskiej w sekcji spraw ogólnych. Mianowany nuncjuszem 15 IX 2004 roku www.catholic.by

${ }^{54}$ www.catholic.by.

${ }^{55}$ Dla przykładu w parafii św. Anny w Mosarzu k. Głębokiego, tamtejszy proboszcz (od 1989 roku) ks. Jozuas Bulka postawił takich krzyży na terenie parafii i okolicy kilkadziesiąt. Weder, Znaki nadziei, s. 11-13.

${ }^{56}$ Ks. Mackiewicz Edward w 1989 roku przyjeżdżał tu dwa razy na zaproszenie do Żupran i Oszmiany, gdzie pomagał ks. Józefowi Zaniewskiemu, proboszczowi w Żupranach. 
Kazimierz Murawa, ks. Antoni Murziński, ks. Jan Niemiec, ks. Jan Romanowicz, ks. Franciszek Rosłan, ks. Stanisław Szoka, ks. Kazimierz Walczuk, ks. Lucjan Dąbrowski, ks. Zdzisław Weder ${ }^{57}$.

Praca przybyłych z Polski salezjanów była trudna. Większość kościołów dopiero co zwróconych katolikom była w opłakanym stanie, bez jakichkolwiek sprzętów, szaf, ksiąg i naczyń liturgicznych. Każdy wyjazd do Polski na 2-3 dni owocował przywiezieniem czegoś najpotrzebniejszego. Warunki mieszkaniowe niejednokrotnie były spartańskie. Źyczliwość ludzi i ich wdzięczność, a zwłaszcza ich głód Boga był odczuwalny. Angażowali się w pracach nad odbudową tamtejszego duszpasterstwa ${ }^{58}$.

W 2003 roku funkcjonowało na Białorusi ok. 370 parafii. Badania wykazały, że $63 \%$ katolików tamtejszych uważa się za Polaków: w diecezji grodzieńskiej $80 \%$, w pińskiej - 70\%, witebskiej 57\%, arch. mińsko-mohylewskiej 35\%.

O każdym z salezjanów, którzy rozpoczynali duszpasterstwo na Białorusi w ostatnim dwudziestoleciu, można by zapisać obszerne strony. Dla przykładu podam niektórych.

Ksiądz Bernard Kaliński przybył najpierw do Grodna, gdzie pracował kilka miesięcy, nie mając początkowo skierowania na konkretną parafię. Tam pod okiem doświadczonego ks. Michała Aronowicza (†1991) spełniał posługę duszpasterska w Grodnie i okolicy.

Wrażenie robiły kolejki do spowiedzi. Po udzieleniu rozgrzeszenia większość penitentów całowała rękę kapłana. Zresztą podobnie było przy każdym podaniu ręki na powitanie. Nie spotykało się rutyniarskiego podejścia do sakramentu pokuty. Po Mszy św. wiele osób pozostawało w kościele. Niektórzy podchodzili do ołtarza na modlitwę. Na Mszę św. wierni gromadzili się odpowiednio wcześniej, nawet kilkadziesiąt minut. Prosta i głęboka pobożność urzekała i świadczyła o żywej wierze ludu.

Po raz pierwszy w życiu w Grodnie ks. Bernard przeżył jedyne w swoim rodzaju doświadczenie, gdy w wigilijny wieczór przeszedł ulicami miasta i na próżno wypatrywał roziskrzonych choinek w oknach mieszkań lub na placach. Wśród tysięcy okien dostrzegł z ulicy bodaj dwa mieszkania z choinkami. Wówczas na Białorusi zrozumiał i docenił piękno polskich tradycji kościelnych związanych nie tylko ze Świętami Bożego Narodzenia, ale także z Bożym Ciałem, I Komunią św. dzieci, uroczystościami odpustowymi, Świętem Zmarłych i procesją na cmentarz, poświęceniem pól, majówkami przy figurach przydrożnych. To wszystko tam było zakazane ${ }^{59}$.

Innym salezjaninem, który wyjeżdżał za wschodnią granicę „,na zaproszenie”, był ks. Stanisław Szmidt, który pod koniec lat osiemdziesiątych ubiegłego stulecia wyjeżdżał na Białoruś. Pomagał ks. Zaniewskiemu w Żupranach przez dwa lata (1988-1989) w okresie Wielkiej Nocy. Głównie chodziło o pomoc w spowiedzi. Garnęły się wówczas tłumy wiernych, których trudno było obsłużyć. Cieszyli się oddawaniem najpierw części kościoła w Oszmianie, a potem

\footnotetext{
${ }^{57}$ Ks. Bernard Kaliński do ks. W. Żurka z 5 X 2006 roku - Lutomiersk (zb. aut.)

${ }^{58}$ Ks. Bernard Kaliński do ks. W. Żurka z 5 X 2006 roku - Lutomiersk (zb. aut.)

${ }^{59}$ Ks. Bernard Kaliński do ks. W. Żurka z 5 X 2006 roku - Lutomiersk (zb. aut.).
} 
i w Smorgoniu i gdzie indziej. W dniach 15-18 III 1989 roku ks. Szmidt wygłosił też „minirekolekcje” parafialne w Smorgoniu, gdzie zaczynał pracę ks. Henryk Kulaszewicz. Pomagał także księdzu Rafałko w Oszmianie. W latach 1997 i 1999 głosił rekolekcje współbraciom w Szczuczynie u ojców pijarów i w Nowogródku. Wcześniej jeszcze kilka razy przybywał z pomocą duszpasterską ks. Wiesławowi Dąbrowskiemu w Nowojelni i Dworcu oraz w kościele filialnym ${ }^{60}$.

Do dzisiaj na Białorusi zostały erygowane 4 salezjańskie wspólnoty (domy) zakonne z przełożonym (dyrektorem) na czele: Boruny ${ }^{61}$, Zdzięcioł (Dzyatlava) ${ }^{62}$, Mińsk $^{63}$, Smorgoń (Smarhon) ${ }^{64}$. Oprócz Mińska, gdzie salezjanie budują kościół w dzielnicy miasta Sriebrianka i prowadzą Centrum Pastoralno Młodzieżowe, wszystkie placówki mają charakter duszpasterski. Dzisiaj salezjanie obsługują 9 parafii: Bogdanowo, Borowlany, Boruny, Zdzięcioł, Mińsk, Niestaniszki (Niestanishki), Nowojelnia (Navayelnya), Smorgoń, Worniany (Varniany), Żuprany (Zhuprany). Z tej liczby 3 w diecezji mińsko-mohylewskiej: Bagdanowo (dek. wołożyński), Borowlany i Mińsk. Pozostałe 6 parafii w diecezji grodzieńskiej: Boruny (z dojazdem do Krewa), Niestaniszki, Nowojelnia (z dojazdem do Dworca), Smorgoń, Woroniany (z dojazdem do Worony i Kluszczan), Zdzięcioł, Żuprany.

Parafia Świętego Michała Archanioła w Bogdanowie (obwód Mińsk, rejon Wołożyn, arch. mińsko-mohylewska). Po wyznaczeniu granic parafii przez Piotra Paca w drugiej połowie XVII w. parafia została ufundowana. Konsekracji kościoła parafialnego dokonał w 1690 roku bp Michał Słupski, administrator wileński. Przeciągające przez te tereny wojska francuskie Napoleona dokonały zniszczeń świątyni parafialnej. Jej remont podjął w 1846 roku Ferdynand Ruszczyc, dziadek sławnego artysty. Duszpasterzem-administratorem kościoła w tym czasie był ks. Stanisław Sokołowski.

Działania zbrojne w czasie II wojny światowej spowodowały, że w czasie pożaru wioski w 1944 roku spłonęła także świątynia. Jej odbudowy podjął się ks. Stanisław Kozłowski (1894-1979) na fundamentach spalonego kościoła. Odbudową kierował główny budowniczy Andrzej Izatowicz Guściański. Po krótkim okresie pracy przy odbudowie prace przerwano, a budowlę przeznaczono na skład-magazyn. Do ostatecznej rozbiórki kościoła doszło w 1976 roku $^{65}$.

Po przeszło 20-letniej przerwie katolicka społeczność Bogdanowa w 1995 roku otrzymała od stosownych władz pozwolenie na restaurację kościoła, co w praktyce oznaczało jego budowę, od końca lutego tego roku. Ten trud podjęli Ojcowie

\footnotetext{
${ }^{60}$ Relacja ks. Stanisława Szmidta z 1 X 2006 roku - Łódź (zb. aut.).

${ }^{61}$ Należą placówki duszpasterskie: Bogdanowo (Bahdanava) i Żuprany.

${ }^{62}$ Należy placówka duszpasterska w Nowojelni.

${ }^{63}$ Przynależy placówka duszpasterska w Borowlanach (Baraulanach).

${ }^{64}$ Przynależą placówki duszpasterskie w Niestaniszkach i Wornianach.

${ }^{65}$ Źródłem powyższych danych jest dokument sporządzony w 1846 r. a znaleziony po 150 latach - w 1996 r. w fundamentach kościoła w oryginalnej i hermetycznie zamkniętej butelce. Dokument ten był przygotowany przez Hannę Ruszczyc (1800-1874), matkę Ferdynanda Ruszczyca - malarza. Ks. Stanisław Ługowski do ks. Waldemara Żurka z 9 I 2007 r. (zb. aut.).
} 
Franciszkanie z sąsiedniego klasztoru w Holszanach, którzy w Bogdanowie podjęli pracę duszpasterską. Obecnie proboszczuje tam ks. Stanisław Lugowski ${ }^{66}$.

Parafia Maryi Wspomożenia Wiernych w Borowlanach (obwód Mińsk, arch. mińsko-mohylewska). Borowlany, miejscowość podmiejska stolicy Białorusi Mińska położona jest ok. $30 \mathrm{~km}$ od centrum miasta. Obecnie Borowlany liczą 15000 mieszkańców. Ta liczba systematycznie wzrasta. Jesienią 2006 roku ropoczęto budowę wokół kaplicy pięciu bloków mieszkalnych 9-piętrowych. Po ich ukończeniu stanie dalszych sześć. Na terenie parafii są dwie szkoły średnie i dwa przedszkola oraz siedem szpitali republikańskich.

W początkach istnienia parafii czyli od 2001 roku Msze św. w niedzielę sprawowane były w hospicjum dla weteranów, a katecheza odbywała się w domu jednej z parafianek. Staraniem ks. Igora Łaszuka (Ihar Lachouk) i z pomocą organizacji dobroczynnej Renovabis i dobrodziejów w 2003 roku stanęła w Borowlanach kaplica drewniana, która pomieści do 150 osób. Od tego roku Msze św. w niedziele i święta sprawowane są w kaplicy. Podobnie i zajęcia katechetyczne z dziećmi i młodzieżą. Liczba katolików uczestniczących w niedzielnej Mszy św. waha się od 100 do 150 wiernych ${ }^{67}$.

Od jesieni 2005 roku nabożeństwa i Msze św. odprawiane są codziennie o godz. 18.00, a w niedzielę o godz. 12.00. Siostra Walentyna Kot, salezjanka z Mińska, prowadzi katechezę od przedszkolaków do młodzieży włącznie. Katechezą objętych jest ok. 30 osób. Pani organistka prowadzi chór parafialny dla dzieci i młodzieży. Grupa ministrantów spotyka się na cotygodniowych zebraniach formacyjnych.

Od września 2005 roku proboszczem w Borowlanach jest ks. Kazimierz Szydełko ${ }^{68}$. Mieszka we wspólnocie salezjańskiej im. św. Jana Bosko w Mińsku i do parafii w Borowlanach dojeżdża codziennie. Po spotkaniu z administratorem diecezji mińsko-mohylewskiej, biskupem Antonim Dziemianko, planowane jest objęcie przez salezjanów opieką duszpasterską katolików, którzy przybywają tu $\mathrm{z}$ całej Białorusi na leczenia. Słusznym wydaje się aby jeden dzień tygodnia przeznaczyć dla jednego szpitala, a w razie konieczności i na wezwanie udawać się także do pacjentów innych szpitali. $Z$ pewnością salezjanie już dzisiaj uwzględniają potrzebę budowy w Borowlanach kościoła parafialnego ${ }^{69}$.

${ }^{66}$ Ks. Stanisław Ługowski do ks. Waldemara Żurka z 9 I 2007 roku (zb. aut.).

${ }^{67}$ Relacja ks. Kazimierza Szydełko z 17 XII 2006 roku - Mińsk (zb. aut.).

${ }^{68}$ Ks. Szydełko Kazimierz, ur. 17 VI 1957 roku w Nowej Wsi, nowicjat odprawił w Kopcu k. Częstochowy i tam złożył śluby 21 VIII 1976 roku, studia seminaryjne w Krakowie, święcenia kapłańskie 18 VI 1986 w Krakowie. Kolejne 6 lat pracował na parafii w Częstochowie-Stradomiu. W 1992 roku wyjechał na Wschód. Najpierw pracował w Odessie na Ukrainie w parafii Świętego Piotra i w parafii Matki Bożej Wniebowziętej wraz z ks. Ignacym Ryndzionkiem, gdzie proboszczem był ks. Tadeusz Hoppe. W 1993 roku udał się do pracy w Moskwie. Kaliński, Rodzina Salezjańska w Polsce, s. 383.

${ }^{69}$ Relacja ks. Kazimierza Szydełko z 17 XII 2006 roku - Mińsk (zb. aut.). 
Parafia Świętych Apostołów Piotra i Pawła w Borunach (obwód Grodno, rejon Oszmiana, diec. grodzieńska). Świątynia i przyległy do niej klasztor należał w przeszłości do bazylianów. Ufundowana została w 1691 roku przez szlachcica Michała Pieślaka, na miejscu, gdzie w lesie na drzewie miał się ukazać - według tradycji - obraz Matki Bożej. Wybudowana świątynia wkrótce stała się miejscem kultu MB Boruńskiej. Murowany barokowy kościół i zabudowania klasztorne zbudowane zostały w latach 1747-1757 wg projektu architekta Aleksandra Osikiewicza. Po likwidacji unii w 1839 roku klasztor został zamknięty. W 1841 roku przejęli go mnisi prawosławni, a kościół zamieniono na cerkiew. Klasztor prawosławny został zamknięty w 1899 roku, a świątynię zwrócono katolikom w 1919 roku. Od tego czasu jest nieprzerwanie czynna, mimo burzliwych lat komunistycznych rządów ${ }^{70}$.

W kościele znajduje się słynący łaskami obraz MB Boruńskiej. Przed zamknięciem klasztoru bazylianie wywieźli cudowny obraz i zastąpili go kopią. Oryginał przechowywany w różnych miejscach powrócił do boruńskiej świątyni w 1992 roku. Święto Matki Bożej Boruńskiej obchodzone jest 29 sierpnia. Wewnątrz świątyni znajduje się źródełko, mające dla wierzących moc uzdrawiającą.

Pierwszym proboszczem salezjańskim został w Borunach ks. Henryk Boguszewski w 1991 roku. W oddalonej o 10 km miejscowości Krewa ks. Boguszeski wybudował kościół i tamtejszą społeczność objął opieką duszpasterską. W Krewie połowa mieszkańców to prawosławni, reszta katolicy. Na początku ks. Boguszewski zaapelował $\mathrm{z}$ ambony o pomoc finansową. I stała się rzecz niezwykła. Pierwszą ofiarę pieniężną na budowę kościoła przyniósł osobiście tamtejszy ksiądz prawosławny, z którym proboszcz katolicki utrzymuje bardzo dobre kontakty, podobnie jak i z wierzącymi prawosławnymi ${ }^{71}$.

Po ks. Boguszewskim przejął probostwo ks. Jan Niemiec, który po dwu latach pracy w Korostyszewie na Ukrainie przybył na Białoruś. W Borunach pracował od kwietnia 1996 roku do grudnia 1999 roku. Następnie przybył do Borun na proboszcza ks. Jacek Falkowski z Saratowa w Rosji, który w Borunach pracował do lipca 2000 roku, po czym powrócił do Polski. Kolejnym proboszczem w Borunach został ks. Lucjan Dąbrowski jako dyrektor i proboszcz do chwili obecnej.

Parafia pw. Bożego Ciała w Dworcu (obwód Grodno, rejon Zdzięcioł, dek. Zdzięcioł, diec. grodzieńska). Tamtejszą placówkę wychowawczo - dydaktyczną salezjanie organizowali od 1921 roku. W 1903 roku zmarł tragicznie w Petersburgu książe Michał Radziwiłł. Jego żona Maria z Zawiszów Radziwiłłowa ${ }^{72}$ zorganizo-

${ }^{70}$ G. Rąkowski, Ilustrowany przewodnik po zabytkach kultury na Białorusi, Warszawa 1997 , s. $24-25$.

${ }^{71}$ Weder, Znaki nadziei, s. 16.

${ }^{72}$ Maria Radziwiłłowa, ur. w 1860 roku w Warszawie, wszechstronnie wykształcona (mówiła po francusku, angielsku, niemiecku, włosku), po śmierci męża poświęcała się w szczególny sposób działalności filantropijnej. Przejęła po mężu zakład dla chłopców „Nazaret”, któremu się całkowicie poświęciła. Gdy po 1905 roku rząd rosyjski zezwolił zakładać szkoły prywatne, Maria łożyła poważne sumy pieniężne na utrzymanie placówek dydaktycznych, głównie na warszawskiej Pradze. W tej pracy pomagał jej ks. Alojzy Volkmer. Była fundatorką kościoła romańskiego w majątku ro- 
wała dla salezjanów fundację w Dworcu. Przekazała pałac, 250 ha ziemi i $1000 \mathrm{~h}$. lasów na cele dobroczynne - dla sierot po pierwszej wojnie światowej. Pierwszym dyrektorem placówki został ks. Ludwik Gostylla, a dnia 1 IV 1922 roku przybyła do Dworca pierwsza grupa 24 sierot $^{73}$. Całą realność salezjanie przejęli na własność w 1927 roku. Na bazie zorganizowanych warsztatów rzemieślniczych (stolarski i szewski) salezjanie otworzyli w Dworcu Szkołę Rzemiosł, która w 1925 roku otrzymała prawa państowe. W 1934 roku salezjanie przejęli duszpasterstwo w miejscowej parafii Bożego Ciała. Pierwszym proboszczem został ówczesny przełożony placówki ks. Jan Żak.

Kościół i plebania znajdowały się po drugiej stronie miejscowości, w odległości około kilometra drogi. Granice parafii dworzeckiej określone zostały już w 1516 roku przez Mikołaja Kieżgiałowicza. Kościół murowany ufundowała w 1905 roku Maria Radziwiłłowa. Do parafii w 1932 roku należało 13 miejscowości (Bartoszki, Dworzec, Koćki, Kulikowszczyzna, Obelkowicze, Ochoniany, Ochonów, Pietrasze, Połonka Mała, Połonka Wielka, Repki, Wasiewicze, Zychy) z 3553 wiernymi i kościół filialny w Nowojelni, oddalonej od Dworca o sześć kilometrów ${ }^{74}$.

Po wrześniu 1939 roku większość salezjanów w Dworcu rozproszyła się. Przez wojnę proboszczował tam ks. Wacław Rybicki (spowiednik od 1938 roku w Zakładzie św. Józefa), któremu udało się tam pozostać do końca wojny. Po wojnie wyjechał pierwszym polskim transportem w ramach tzw. repatriacji. W Dworcu pozostali jedynie dwaj salezjanie: ks. Ludwik Witkowski i ks. Jan Ignacy Wielkiewicz. Wyrzuceni z pomieszczeń kościelnych już w jesieni 1939 roku mieszkali prywatnie. Ks. Wielkiewicz wkrótce przeszedł na parafię w Nowojelni, a od kwietnia 1946 roku do Zdzięcioła. W Dworcu pozostał jedynie ks. Witkowski. Parafianie przyjmowali wyrozumiale jego niedomagania zdrowotne. Oprócz duszpasterskich powinności malował obrazy, chodził po tamtejszych domostwach i ,zarabiał” ozdabiając obrusy, w zamian za utrzymanie i wyżywienie. Pracował do ostatka. Jedynie w dniu Wszystkich Świętych nie sprawował liturgii. Zmarł w Dzień Zaduszny - 2 XI 1952 roku.

Po śmierci ks. Ludwika Witkowskiego tamtejszy kościół zamieniono na magazyn nawozów sztucznych, a od 1978 roku na stajnię dla leczonych koni. Okoliczna ludność była zbyt uboga aby sprostać grzywnom nakładanym na kościół. Do plebanii dobudowano w latach powojennych drugą część i całość przeznaczono na szpital wiejski. Ta sytuacja utrzymała się przez kilkadziesiąt powojennych lat rządów komunistycznych, walki z Kościołem i dewastacji jego obiek-

dzinnym Dworzec, kościoła w Ząbkach, drewnianego kościoła i plebanii na Nowym Brudnie, kaplicy na Kamionku oraz bazyliki Serca Jezusowego na warszawskiej Pradze, wybudowanego przez salezjanów. Ś.p. Ks. Maria Michałowa Radziwiłłowa, „Bazylika”- Miesięcznik informacyjny o życiu parafialnym 6 (1930) $\mathrm{nr}$ 7, s. 1-3.

${ }^{73}$ Kolejnymi dyrektorami byli: ks. Wiktor Zdrzałek (1928), ks. Tomasz Kopa (1928-1929), ks. Antoni Kotarski (1929-1933), ks. Jan Żak (1933-1937), ks. Jan Kapusta (1937-1939). Elenco generale della Societa di S. Francesco di Sales. Antico continente 1922-1939, Torino.

${ }^{74}$ Catalogus ecclesiarum et cleri archidioecesis vilnensis pro anno domini 1936, Vilnae 1936, s. 126. 
tów. Komunistom nie powiódł się plan zagospodarowania obiektu kościelnego w Dworcu. Dochodziło także do aktów sabotażu ze strony tamtejszej ludności, stąd ostatecznie kościół stał niezagospodarowany i porzucony.

$\mathrm{Na}$ skutek starań wiernych i kapłanów, pod przewodnictwem proboszcza i dziekana w Nowogródku, ks. Antoniego Dziemianko, w 1989 roku odzyskano kościelną ruinę w Dworcu bez przedmiotów kultowych. Ludzie odebrali go siłą i własnymi rękami przywracali go do funkcji sakralnych. Odzyskany obiekt był zdewastowany. Występowały duże ubytki dachówek, co spowodowało zgnicie krokwi dachowych. Na ścianach murowanych brakowało cegieł, w oknach widoczne były szczątki futryn. Nie zachowało się nic z wyposażenia kościoła ${ }^{75}$. Zachowała się obok kościoła mogiła przedwojennego proboszcza Litwina ks. Jana Kurwel-Karwelisa, zmarłego w 1933 roku w wieku 59 lat.

Pierwszym duszpasterzem kościoła Bożego Ciała w Dworcu, po jego odzyskaniu, był ks. Bernard Kaliński, proboszcz w Zdzięciole, który odprawił pierwszą Mszę św. w 1990 roku. Po nim parafię w Dworcu obsługiwał ks. Kazimierz Walczuk, proboszcz i następca ks. Kalińskiego w Zdzięciole.

$\mathrm{Na}$ wniosek inspektora salezjanów Okręgu Wschodniego z Moskwy, ks. Zdzisława Wedera, ordynariusz w Grodnie, bp Aleksander Kaszkiewicz mianował 3 X 1994 roku proboszczem w Dworcu i Nowojelni ks. Wiesława Dąbrowskiego (senior) ${ }^{76}$, który od końca sierpnia poprzedniego roku pracował jako wikariusz parafialny w Lidzie na Słobódce. Objęcie obydwu parafii przez ks. Wiesława nastąpiło dnia 9 X 1994 roku w obecności ks. Kazimierza Walczuka, dziekana zdzięciolskiego.

Na początek gromadziło się na liturgię mszalną ok. 60 osób. Nowy proboszcz rozesłał 600 listów do parafian, w których się przedstawił, prosił mieszkańców o zadeklarowanie swojej wiary i zapraszał katolików do uczestnictwa w życiu parafialnym i sakramentalnym. Zarówno w Dworcu i Nowojelni rozpoczął od celebracji codziennej Mszy św. w godzinach wieczornych, a w niedziele i święta przed i po południu, w obu parafiach.

Wielką nadzieję pokładał w zapowiedzianej wizycie duszpasterskiej (kolę-

${ }^{75}$ Zabytkowe dwie rzeźby świętych Piotra i Pawła znajdują się w muzeum w Mińsku, podobnie dzwony kościelne. Dnia 22 IX 2004 roku proboszcz otrzymał dokument stwierdzający, że 23 XI 1978 roku zabrano z kościoła w Dworcu zabytkowe figury św. Piotra i św. Pawła oraz dzwony. Wszystkie zrabowane zabytki są w muzeum w Mińsku. Obecnie czynione są starania o ich zwrot za pośrednictwem prawnika zatrudnionego w Kurii Biskupiej w Grodnie. APN, T. Kronika parafii Nowojelnia-Dworzec, t. 5, s. 227, Tom 10, s. 489.

${ }^{76}$ Ks. Wiesław Dąbrowski, ur. 17 X 1936 roku w Rembertowie, nowicjat odbył w Czerwińsku, gdzie złożył pierwsze śluby 2 VIII 1953 roku, studia filozoficzne w Kutnie-Woźniakowie, teologia w Lądzie, święcenia kapłańskie 9 VI 1965 roku w Lądzie. Budowniczy kościołów: w Woźniakowie (1953-1955), Nawodnej k. Chojny (1963-1966), Dłusku k. Chojny (1974-1975), Baniewicach k. Bani (1975-1977), Strzelczynie k. Chojny (1977-1978), Smolnicy k. Dębna (1983-1984), Grzymiradzu k. Dębna (1984-1985), Sycewicach k. Słupska (1986-1989), Nowojelni (1984-2000) oraz budowniczy plebanii w Swobnicy (1978-1980), Sycewicach (1989-1990), Nowojelni (1984-2000) wreszcie kaplicy w Chrólczycach (2000). Dnia 24 VIII 1993 roku z Rumi wyjechał do pracy w Republice Białorusi. Został w Lidzie u ks. Kazimierza Szoki jako wikariusz parafialny. Kaliński, Rodzina Salezjańska w Polsce, s. 273. 
dzie), na której deklarującym się jako katolicy zostały zaprowadzone kartoteki personalne. Okazało się, że w Dworcu mieszkają 42 rodziny katolickie, łącznie 133 wiernych, oraz 27 osób samotnych; rodzin prawosłanych 37.

Natychmiast po objęciu probostwa zaprosił do parafii Nowojelnia i filialnego Dworca na przeprowadzenie misji parafialnych salezjanów z Polski. W dniach 7-11 XI 1994 roku pierwsze misje parafialne po 1939 roku, czyli po 55 latach wygłosili w parafiach księża: Kazimierz Gałaj i Wojciech Majchrzak. Na pamiątkę postawiono dębowe krzyże misyjne, wykonane przez pana Antoniego.

Największe trudności napotykał nowy proboszcz w gromadzeniu na naukę religii dzieci i młodzież. Większość z nich nie umiała pacierza. W rodzinach nie modlono się, bo rodzice nie umieli lub byli obojętni, a teraz dopiero dzieci wchodziły pierwszy raz w życiu do świątyni katolickiej. Wprawdzie przychodziły pod kościół, może z ciekawości, stały tam w czasie Mszy św., a kiedy ksiądz od ołtarza lub ktoś inny wychodził zaprosić ich do środka, wówczas uciekali. Należało rozpocząć wszystko od podstaw. Na początek, dzieci mówiące językiem rosyjskim otrzymały książeczki obrazkowe w dwu językach: rosyjskim i polskim z modlitwami katechizmowymi. Od 1 IX 2003 roku zainaugurowana została w parafii katecheza dla dorosłych. Wyznaczono odpowiedni czas na naukę i zdawanie poszczególnych modlitw z końcową nagrodą ${ }^{77}$.

Dnia 9 I 1995 roku proboszcz poświęcił nowe tabernakulum do kościoła w Dworcu, które zastąpiło dotychczasowe drewniane. W grudniu 1996 roku wstawiono w absydzie kościoła po prawej stronie witraż św. Piotra, po lewej przestawiający św. Pawła. Dwa lata później proboszcz rozpoczął wykonywać własnoręcznie witraże do otworów okiennych kościoła. To kosztowne przedsięwzięcie zaplanował na kilka lat. W międzyczasie podjął naprawę dachu kościelnego, a raczej wymianę wszystkich krokwi drewnianych, które zgniły. Obecnie kościół został pokryty blachą.

W bogatej oprawie liturgicznej organizował I Komunię dla dzieci: 1995 roku - 15 dzieci, 1996 roku - 14, 1997 roku - 11.

Parafia w Dworcu otrzymała pozwolenie na założenie i lokalizację nowego cmentarza parafialnego o powierzchni 2 hektary. Przygotowany krzyż metalowy wierni zanieśli procesyjnie na wyznaczony teren i w uroczystość św. Antoniego 13 VI 2001 roku został on poświęcony wraz z gruntem przeznaczonym na pochówki ${ }^{78}$.

W kościele dworeckim w przeszłości przez lata stały konie, które własnymi odchodami zniszczyły posadzkę. Oparami nawozu końskiego nasiąknęły ściany. Należało więc kolejno zbijać tynki, odgrzybiać ściany i zakładać boazerię. Te prace rozpoczęto wiosną 2004 roku $^{79}$.

W 2000 roku do parafii Dworzec przynależały wioski: Agarodniki, Bakszty, Bartosze, Bartaszy, Butwiłowiczy, Cieciejki, Koćki, Obielkowicze, Ozierany Pietrasze, Połonka Mała, Połonka Wielka, Rabki, Staryna, Wasiewicze, Zychy.

\footnotetext{
${ }^{77}$ APN, T. Kronika parafii Nowojelnia-Dworzec, t. 5, s. 220.

${ }^{78}$ APN, T. Kronika parafii Nowojelnia-Dworzec, t. 5, s. 223.

${ }^{79}$ APN, T. Kronika parafii Nowojelnia-Dworzec, t. 8, s. 431.
} 
Dzisiaj na terenie parafii mieszka 1900 mieszkańców, w tym 950 katolików. Sprawuje się dla nich liturgię w trzech językach: polskim, rosyjskim i białoruskim.

Parafia św. Jana Bosko w Mińsku (obwód Mińsk, arch. mińsko-mohylewska). W stolicy kraju, w dzielnicy Serebrianka w 1997 roku salezjanie zapoczątkowali swoją obecność. Zamieszkali w prywatnym mieszkaniu przy ul. Jakubowa i zainicjowali pracę duszpasterską $\mathrm{w}$ prowizorycznej kaplicy. Obecnie budują kościół św. Jana Bosko i czynnie angażują się w duszpasterstwo młodzieży.

Współbracia z Mińska obsługują ponadto parafię Pauliszcze, oddaloną o 40 $\mathrm{km}$ od stolicy.

Parafia Matki Bożej Dobrej Rady w Niestaniszkach (obwód Grodno, rejon Smorgoń, diec. grodzieńska, dek. Smorgoń). Parafia ufundowana w 1497 roku przez Bogdana Andrzejewicza. Nowa murowana świątynia pochodzi z 1905 roku. Konsekrowana przez abpa Romualda Jałbrzykowskiego w 1928 roku. Parafia leży na granicy diecezji grodzieńskiej w dekanacie smorgońskim. Świątynia neogotycka, była czynna przez lata powojenne.

Pierwszym proboszczem salezjańskim w Niestaniszkach został ks. Michał Kłoda $(† 2006)$, dotychczasowy wikariusz parafialny w Smorgoniu. Pracował tam pięć lat. Do parafii należy ok. 700 wiernych. Po ks. Michale parafię przejął w 1999 roku ks. Kazimierz Walczuk, poprzednio proboszcz i dziekan w Zdzięciole. W 2005 roku parafia w Niestaniszkach świętowała swoje 100-lecie ${ }^{80}$.

Parafia Serca Pana Jezusa w Nowojelni (obwód Grodno, rejon Zdzięcioł, diec. grodzieńska). Do 1936 roku wierni z Nowojelni k. Nowogródka i okolicy należeli do parafii Bożego Ciała w Dworcu. Duszpasterzujący tam salezjanie w 1936 roku przenieśli drewniany kościół z innej wioski i zmontowali go w Nowojelni, z odległości $25 \mathrm{~km}$ od jeziora Świteź, znanego nam z poezji romantyków, zwłaszcza Adama Mickiewicza. W 1937 roku wikariusz dworzecki, ks. Jan Ignacy Wielkiewicz pełnił funkcję prefekta religii w szkole w Nowojelni i tamtejszego duszpasterza. W każdą niedzielę i święto dojeżdżał bryczką do Nowojelni na sprawowanie liturgii mszalnej.

Ostatnim proboszczem w Nowojelni był ich przedwojenny duszpasterz, ks. Wielkiewicz, który w kwietniu 1946 roku przejął po ks. Józefie Sawickim obowiązki proboszcza i dziekana w Zdzięciole i tam zamieszkał. Po jego odejściu z Nowojelni drewniana świątynia została w 1957 roku zamieniona na salę gimnastyczną, potem na magazyn, wreszcie na kino-teatr. Przykościelną wieżę-dzwonnicę ścięto a dzwony spiżowe zabrano.

Dopiero po Gorbaczowskiej „odwilży” kościół został odzyskany. Było to możliwe dzięki ks. Antoniemu Dziemianko, dziekanowi i proboszczowi z Nowogródka, który z pomocą miejscowych katolików odzyskał kościół. Przez

${ }^{80}$ Catalogus ecclesiarum et cleri archidioecesis vilnensis pro anno domini 1929, Vilnae 1929, s. 81; Relacja ks. Kazimierza Walczuka z 18 XII 2005 roku- Niestaniszki (zb. aut.). 
około dwa miesiące 1991 roku Msza św. była odprawiana przy zachowanym przedwojennym krzyżu misyjnym przed świątynią, a następnie w przedsionku kościoła. Obecnie obok dotychczasowego krzyża postawiono nowy. Mianowany proboszczem 4 X 1994 roku ks. Wiesław Dąbrowski rozpoczął odprawianie Mszy św. w części kinowej, przedsionku dobudowanym do kina. Tak modlono się przez trzy lata. Początkowo uczestniczyło ok. 40 wiernych. W czasie pierwszej wizyty duszpasterskiej, zaprowadzając kartotekę personalną parafii, proboszcz zorientował się o faktycznej liczbie katolików. W wybranych kilku wioskach rodzin katolickich mieszkało: Nowojelnia 101 rodzin - 232 wiernych; Bartosze $24-63$; Obielkowicze $16-39$; Ochaniany $12-39$, Ozierany $18-37$. W sumie 213 rodzin z 543 wiernymi oraz 112 osób samotnych. W wyliczonych miejscowościach dało to ogólną liczbę 655 parafian. Należało więc zdynamizować duszpasterstwo aby przyciągnąć wiernych do Boga ${ }^{81}$.

Ks. Dąbrowski na początek zamieszkał w budynku dawnej plebanii przy ul. Sowieckiej 4 - dwa pokoje. Od 12 III 1995 roku przeniósł się na mieszkanie po zmarłej pani Krasockiej na ul. Krasnoarmiejską 23, gdzie miał cały dom do dyspozycji, do momentu wybudowania nowej plebanii. Po uroczystościach konsekracji kościoła w 2000 roku przeniósł się do nowo wybudowanej plebanii, po sześciu latach wynajmowania mieszkania.

Remont odzyskanego kościoła w Nowojelni rozpoczął ks. Dąbrowski od poświęcenia 1 I 1995 roku pancernego tabernakulum, ofiarowanego przez bpa Aleksandra Kaszkiewicza. Dnia 2 IV 1995 roku przybył z Polski główny majster Jerzy Rosenbajger, który miał nadzorować prace remontowe w obu parafiach: Nowojelni i Dworcu. Dnia 23 VI 1995 roku poświęcił proboszcz obraz Serca Pana Jezusa do głównego ołtarza podarowany przez Solidarność Kolejarzy Okręgu Olsztyńskiego. Od sierpnia tego roku rozpoczęto wymianę ścian drewnianych na murowane z cegły. Prace trwały do 26 IX 1996 roku. Dach pozostał dotychczasowy, przedwojenny. Od początku kwietnia 1996 roku proboszcz wykonywał własnoręcznie witraże do kościelnych otworów okiennych. Wstawienie ostatniego okna zakończył na uroczystość Św. Józefa - 19 III 1998 roku. Tematyka witraży dworzeckich: 1) Wspomożycielka Wiernych, 2) Św. Józef z Dzięciątkiem, 3) Dobry Pasterz, 4-10) Symbole 7. sakramentów świętych. Trzy witraże umieszczono także w salce katechetycznej: Niepokalana, Święta Rodzina z Nazaretu, pelikan karmiący pisklęta własną krwią. Samochód szkła witrażowego podarowała huta szkła w Jaśle. W kwietniu 1999 roku ukończono ołtarz soborowy z czarnego granitu (mensa) i marmuru (nogi). Wszystkie przedsięwzięcia związane z restauracją świątyni zmierzały do odpowiedniego przygotowania jej na konsekrację, która odbyła się 15 VII 2000 roku. Dokonał jej biskup Kaszkiewicz z Grodna. W pierwszą rocznicę konsekracji kościoła w Nowojelni - 15 VII 2001 roku poświęcono nową Drogę Krzyżową, której fundatorem był ks. Henryk Jendryczak i dawni

${ }^{81}$ Prawie tyleż samo stanowili tamtejsi prawosławni: Nowojelnia 127 rodzin, Bartoszy 8 rodzin, Obielkowicze 13, Ochaniany 12, Ozierany 13. Sumarycznie 204 rodziny prawosławne. APN, T. Kronika parafii Nowojelnia - Dworzec, t. 1, s. 25; W. Dąbrowski, Nowojelnia-parafia raduje się poświęcona świątynia, „Słowo Życia”. Gazeta Diecezji Grodzieńskiej, nr 14 z 23 VII 2000 (68), s. 1; Ks. Bernard Kaliński do ks. W. Żurka z 5 X 2006 roku - Lutomiersk (zb. aut.). 
mieszkańcy Nowojelni, dziś Warszawiacy (m. in. Ewa Sitarska). Dnia 28 VI 1999 roku oddane zostały dzwony, wykonane przez Firmę Uno Italia z Warszawy. Odrestaurowany obiekt sakralny po wymianie ścian drewnianych na murowane jest wystarczający. Dawniejsze kino zostało przeznaczone na salkę katechetyczną, w kasie umieszczono kancelarię parafialną, a nad kinem dobudowano mieszkanie dla proboszcza ${ }^{82}$.

Po raz pierwszy odprawiono liturgię mszalną w odbudowanym kościele 24 VIII 1997 roku. Wkrótce potem w dniach 11-12 września tego roku dobyło się nawiedzenie parafii przez statuę MB Fatimskiej. Niezapomnianym przeżyciem była pielgrzymka parafian z Nowojelni (10 osób) na spotkanie 8 VI 1999 roku z Ojcem Świętym Janem Pawłem II w Ełku.

Ponieważ Nowojelnia została w 1986 roku napromieniowana wskutek katastrofy reaktora atomowego $\mathrm{w}$ Czarnobylu, $\mathrm{z}$ tej racji $\mathrm{w}$ ciągu roku szkolnego co miesiąc dwie kolejne klasy dzieci wyjeżdżają do sanatorium, stąd są pewne trudności w ustaleniu stałego terminu przystępowania dzieci do I Komunii św. Odbywała się ona w miarę jak poszczególne grupy zostały przygotowane: w 1995 - 3 dzieci; 1996 - 47; 1997 - 34; 1998 - 26; 1999 - 32; 2000 - 14; 2003 - 16 (w tym 7 dorosłych). Ciekawostką było to, że większość dzieci była prawosławna, ale zapragnęły przystąpić do Komunii św. w kościele katolickim.

Ponieważ w parafii nie było od 62 lat bierzmowania, w grudniu 1998 roku proboszcz rozdał parafianom karty informacyjne, aby zorientować się ile osób pragnie przygotować się do tego sakrementu. „Człowiek dorosły po 14 roku życia - wyjaśniał proboszcz - który wcześniej był u I Komunii św., powinien przyjąć sakrament bierzmowania, który przyjmuje się tylko raz w życiu; kto więc był ochrzczonyw Cerkwi już ten sakrament otrzymał w czasie chrztu św." Sakramentu bierzmowania udzielił biskup w dniu konsekracji kościoła 15 VII 2000 roku. Było to pierwsze bierzmowanie od 1939 roku w parafii Nowojelnia. Uprzednio w przeciągu jednego roku głoszone były konferencje przygotowujące na przyjęcie tego sakramentu. Bierzmowanie przyjęło 130 osób $^{83}$.

Jako salezjanin, ks. Dąbrowski wiele uwagi poświęca dzieciom i młodzieży. Zdając sobie sprawę, że parafia Nowojelnia leży w strefie radiacyjnego napromieniowania Czarnobylem, ks. Wiesław zabiega, aby dzieci z dolegliwościami tarczycy miały możliwość wypoczywać i leczyć się w czasie wakacji. Dzięki Caritasowi Austria za pośrednictwem Caritas Diecezjalnego w Grodnie oraz życzliwości rodzin w Polsce i Austrii organizowany jest wypoczynek wakacyjny dla najmłodszych. Od 1997 roku młodzi parafianie (11-17 osób) wyjeżdżają do rodzin w Austrii, do miejscowości Munderfing, gdzie spędzają wakacje. Ponadto w Polsce i na Białorusi wypoczywało w roku 1998 - 16 dzieci; 2002 - 9, 2003 $-4^{84}$.

${ }^{82}$ APN, T. Kronika parafii Nowojelnia - Dworzec, t. 1, s. 69, 128, 150, 154.

${ }^{83}$ Pismo proboszcza do parafian grudzień 1998 roku, w: APN, T. Kronika parafii Nowojelnia i Dworzec, t. 2, s. 118, 119, 154.

${ }^{84}$ W. Łojko, Kościót tworza ludzie, którym ufamy. Takie listy ciesza, „Słowo Życia”, nr 22 z 24 XII 1999 (54), s. 9. 
Dnia 22 II 1998 roku przełożony Okręgu Wschodniego z Moskwy, ks. Zdzisław Weder poświęcił nowy obraz Matki Bożej Nieustającej Pomocy w bocznym ołtarzu kościoła w Nowojelni. Miejscowy artysta namalował ikonę i od tego dnia w każdą środę wieczorem wierni gromadzą się na nabożeństwo maryjne. Śpiewy wykonywane w czasie tej liturgii napisał muzyk salezjański ks. Idzi Ogerman Mański (1900-1966).

W dniach 26 i 27 VI 1998 roku parafia w Nowojelni gościła Radę Inspektorialną Okręgu Wschodniego. W czasie jej obrad inspektor, ks. Zdzisław Weder, ogłosił nominację proboszcza Wiesława Dąbrowskiego na przełożonego wspólnoty salezjańskiej z siedzibą w Nowojelni. Nominacja Przełożonego Generalnego na dyrektora nosi datę 3 VI 1998 roku - trzechlecie 1998-2001. Ks. Wiesław został mianowany dla placówek i współbraci w nich pracujących: Dworzec, Nowojelnia, Rochatna, Zdzięcioł, Bierdowki, Lida.

Jako proboszcz zatroszczył się o zbiorową mogiłę 10000 Żydów wymordowanych przez Niemców dnia 28 XII 1942 roku w lesie za Nowojelnią we wsi Koćki. Zbiorowa mogiła (61 na $5 \mathrm{~m}$ ) była kiedyś ogrodzona przęsłami drewnianymi umocowanymi na betonowych słupkach. Zachowany jest do dziś w dobrym stanie pomnik na zbiorowej mogile $\mathrm{z}$ tablicą i napisem w języku hebrajskim i rosyjskim. Ogrodzenie w dużym stopniu zniszczone, wymagało naprawy.

W uroczystość patronalną Zgromadzenia Salezjańskiego - św. Jana Bosko, dnia 31 I 2001 roku w parafii Nowojelnia zostało otwarte salezjańskie Oratorium młodzieżowe. Stół do ping-ponga wykonał proboszcz. Każdego dnia dzieci i młodzież przychodzące na lekcje religii mają okazję spędzić czas w Oratorium i na boisku przyległym, uprawiając sport. W okresie zimowym organizowane są konkursy jazdy na nartach. Zarówno dla Oratorium jak i w ogóle dla parafian wyświetlane są często filmy na video. Filmoteka proboszcza liczy 54 tytuły. W katechizacji pomaga Halina Bułygina (2000) ${ }^{85}$.

Z grupy 75 osób młodzieży męskiej i żeńskiej parafii 17 ministrantów obojga płci uświetnia liturgię w kościele.

Przesyłając życzenia bożonarodzeniowe 2001 roku i na Nowy Rok 2002 roku przyjaciołom i dobrodziejom ziemi Białoruskiej, a w szczególności parafii w Nowojelni, ksiądz proboszcz informował adresatów o kolejnym przedsięwzięciu. W miejscowości Chrólczyce, oddalonej o $12 \mathrm{~km}$ od Nowojelni, drewniana kaplica cmentarna była $\mathrm{w}$ ruinie. Wybudowana została $\mathrm{w} 1832$ roku przez rodzinę Żylicz ${ }^{86}$ na cmentarzysku położonym w pobliżu dworku, spalonego w czasie II wojny światowej. Po wojnie kaplica ulegała stopniowemu zniszczeniu. Zawalił się dach, wewnątrz porosły drzewa, okna i drzwi wypadły. Pozostały jedynie drew-

\footnotetext{
${ }^{85}$ APN, T. Kronika parafii Nowojelnia-Dworzec, t. 3, s. 188, t. 4, s. 205, t. 8, s. 435.

${ }^{86}$ Potomkowie właścicieli Chrólczyc żyją obecnie w Angli i Warszawie. Teresa ŻmigrodzkaŻylicz z Warszawy (córka ostatniego właściciela Chrólczyc Józefa Żmigrodzkiego) przekazała kilka informacji o kaplicy. Majątek Chrólczyce należał do jej przodków przez około 200 lat, ostatnio do jej ojca śp. Józefa Żmigrodzkiego, ur. w 1887 roku i zmarłego w 1959 roku w Lublinie. Teresa nie wie, który z ich przodków ją wybudował. Natomiast jej ojciec z dzieciństwa pamiętał, że w kapliczce, lub obok niej, mieszkańcy wioski urządzali tradycyjne obrzędy „Dziadów”. APN, T. Kronika parafii Nowojelnia-Dworzec, t. 6, s. 299, 302.
} 
niane spróchniałe ściany. Grobowiec śp. Stefana Żmigrodzkiego w środku kaplicy zawalił się. Aby tamtejszej ludności, szczególnie osobom w podeszłym wieku, ułatwić uczestnictwo we Mszy św. niedzielnej, którzy od 50 lat nie uczęszczali do kościoła ani cerkwi, proboszcz postanowił ją odbudować. Z początkiem 2002 roku przybyli do proboszcza w Nowojelni przedstawiciele władz państwowych z Grodna, władz rejonu Zdzięcioła i miejscowego Sielskiego Wykonawczego Komitetu w Tarkaczach, aby uzgodnić sprawę rekonstrukcji kaplicy cmentarnej. Pod koniec lutego 2002 roku rozpoczęto prace. Elementy drewniane przygotowano w miesiącach zimowych w Nowojelni, a potem nastąpiło ich montowanie. Prace zakończono pod koniec lipca tego roku. Dnia 28 VII 2002 roku odprawiona została tam pierwsza Mszą św., na którą przybyło 75 osób, katolików i prawosławnych. Od tego dnia w każdą niedzielę o godz. 15.00 jest tam sprawowana Eucharystia. Jej poświęcenia dokonał ordynariusz grodzieński, bp Kaszkiewicz dnia 5 X 2002 roku. Na te uroczystości dyrektor miejscowego kołchozu udostępnił autobus do dowozu parafian z Nowojelni. Kaplica otrzymała tytuł Matki Bożej Wspomożycielki Wiernych. W uroczystości poświęcenia uczestniczyli katolicy i prawosławni. Kaplica służy dla mieszkańców trzech sąsiadujących ze sobą wiosek, którzy obecnie mają ułatwione uczestnictwo we Mszy św. ${ }^{87}$

Od września 2003 roku rozpoczęto stawiać stacje Drogi Krzyżowej - Kalwarię wokół kościoła. Do zimy tego roku wybudowano 6 stacji z utwardzonymi alejkami. Kolejne stacje postawiono w roku następnym.

Myśląc o otwarciu w parafii Domu Młodzieżowego, proboszcz zakupił drewniany dom parterowy ze stodołą i działkę. Budynek w lecie 2003 roku poddał gruntownemu remontowi. W domu znajduje się kaplica z Najświętszym Sakramentem. Zamieszkały w nim na stałe dwie siostry nazaretanki: s. Adriana i s. Agnes. Dom Młodzieżowy został poświęcony przez inspektora z Moskwy, ks. Henryka Boguszewskiego dnia 23 IX 2004 roku. Już na Boże Narodzenie 2004 roku siostry wraz z młodzieżą przygotowały ruchomą szopkę i Jasełka bożonarodzeniowe. Siostry prowadzą w Domu Młodzieży katechezę oraz dokarmiają biedne dzieci. Dom jest otwarty, a młodzież przychodzi przed i po lekcjach. Siostry organizują wszelkie akcje kulturalne, np. Mikołaja, opłatek, wspomniane już Jasełka, chórek dziecięcy, naukę szycia itp. ${ }^{88}$

Od października 2004 roku objęto pomocą 10 wielodzietnych rodzin. Gromadzone są produkty żywnościowe i ubrania a dzieci przysyłane przez rodziców otrzymują takowe. Kontynuowanie tej pomocy zależeć jednak będzie od kondycji finansowej Domu Młodzieżowego oraz od uzyskania dodatkowych pomieszczeń. Stąd ks. Dąbrowski poczynił starania o wybudowanie osobnego domu dla młodzieży, ale już murowanego i piętrowego. Otrzymał pozwolenie na postawienie sal sportowych, kuchni i jadalni. W 2004 roku rozpoczęto prace przygotowawcze do budowy i zalano fundamenty ${ }^{89}$.

Obecnie do parafii w Nowojelni należą miejscowości: Chrólczyce, Cieciejki, Litaworce, Międzygóra, Ochoniany, Rabki, Szajbakowa, Tołkuny, Warakom-

\footnotetext{
${ }^{87}$ APN, T. Kronika parafii Nowojelnia-Dworzec, t. 6, s. 303, $304 .$.

${ }^{88}$ APN, T. Kronika parafii Nowojelnia-Dworzec, t.10, s. 500.

${ }^{89}$ APN, T. Kronika parafii Nowojelnia-Dworzec, t. 10, s. 477-488, 497, 498.
} 
szczyzna, Wiedrowicze. W 2003 roku parafia liczyła ok. 5000 mieszkańców, w tym 390 katolików. W parafii odprawiana jest liturgia w języku białoruskim, rosyjskim i polskim.

Parafia św. Michała w Smorgoniu (obwód Grodno, rejon Smorgoń, diec. grodzieńska). Pierwotnie zbór kalwiński, renesansowy, zbudowany został w Smorgoniu w latach 1552-1553, z fundacji wojewody brzesko-litewskiego Krzysztofa Zenowicza, wykończony przez jego syna Jerzego. Syn Jerzego - Michał Bogusław przeszedł na katolicyzm, a jego siostra Zofia, po śmierci brata w 1621 roku przekazała świątynię katolikom, konsekrowaną jako kościół pw. Świętej Trójcy. W 1866 roku zamieniony został kościół na cerkiew prawosławną pw. św. Michała, a w 1921 roku zwrócony ponownie katolikom. W 1947 roku kościół parafialny został zamknięty przez reżym komunistyczny. W czasach stalinowskich mieścił się w nim magazyn, następnie sklep, sala wystawowa, muze$\mathrm{um}^{90}$.

Dnia 25 III 1989 roku katolicy tamtejsi odzyskali swój obiekt sakralny. Parfię objął ks. Henryk Kulaszewicz, pomagali mu doraźnie kapłani przyjeżdżający z Polski (ks. Bernard Kaliński, ks. Jerzy Gocko z Lublina) oraz do 1997 roku ks. Michał Kłoda jako wikariusz parafialny. Przybywających księży w szczególny sposób zachwycały śpiewy wiernych. W katechizacji zaangażowane są siostry salezjanki z Polski i Słowacji oraz panie katechetki. Na katechizację uczęszczało wówczas ponad 700 dzieci i spora grupa młodzieży. Ks. Henryk zorganizował grupę ponad 60 ministrantów, z których kilku wstąpiło do salezjanów. Pierwsze rekolekcje po odzyskaniu kościoła wygłosił w dniach 15-18 III 1989 roku ks. Stanisław Szmidt. Obecny, nowoczesny wystrój w kościele smorgońskim jest autorstwa ks. Tadeusza Furdyny, salezjanina ${ }^{91}$.

Staraniem proboszcza Kulaszewicza powstało w parafii Centrum Młodzieżowe. Ksiądz zakupił dom kultury w stanie opłakanym. Po odpowiednich przeróbkach budowlanych możliwe stało się urządzenie tam części mieszkalnej dla duszpasterzy i przeznaczenie odpowiednich pomieszczeń na potrzeby młodzieży - Centrum. W nim prowadzona jest katechizacja (ok. 1000 katechizowanych) dzieci i młodzieży oraz otwarto Oratorium młodzieżowe. Tam młodzież uczy się języków obcych (angielski, łaciński, niemiecki, polski i włoski). W ramach Centrum funkcjonuje grupa Anonimowych Alkoholików, Współpracownicy Salezjańscy, Legion Maryi i dwa chóry parafialne: polski i białoruski. W najbliższym czasie planowane jest otwarcie pracowni komputerowej.

Parafia w Smorgoniu przekazana została przez ordynariusza grodzieńskiego salezjanom na stałe. Tamtejsze Centrum jest także własnością Zgromadzenia. W ostatnich latach została wybudowana własna kotłownia na gaz, przy pomocy której ogrzewany jest kościół i budynek Centrum ${ }^{92}$.

${ }^{90}$ Rąkowski, Ilustrowany przewodnik po zabytkach kultury na Białorusi, s. 224-225.

${ }^{91}$ Szmidt, Białoruskie rekolekcje, s. 16; APN, T. Kronika parafii Nowojelnia - Dworzec, t. 1, s. 40.

${ }^{92}$ Relacja ks. Zdzisława Wedera z 7 XI 2006 roku - Kraków (zb. aut.). 
Obecnie parafię obsługuje od 2002 roku ks. Zdzisław Weder. W 2006 roku (do listopada) w parafii udzielono 210 chrztów, 140 ślubów i 120 pogrzebów.

W 2003 roku miasto Smorgoń świętowało 500-lecie istnienia. Podobny jubileusz świętowała parafia.

Parafia św. Jerzego Męczennika w Wornianach (obwód Grodno, rejon Smorgoń, diec. grodzieńska, dek. Ostrowiec). Świątynia parafialna po erygowaniu parafii wybudowana została w 1462 roku przez Mariana Songayłło. Nowa i poszerzona świątynia (ze środków Marii Abramowicz) została konsekrowana w 1769 roku przez abpa Eppo Tomasza Zieńkowicza. Obecna murowana i ukończona w 1903 roku, zbudowana dzięki ofiarności parafian ${ }^{93}$

Proboszczem od 1990 roku jest ks. Zdzisław Pikuła, od 1992 roku dziekan dekanatu Ostrowiec. Na Białoruś przybył z parafii w Suwałkach w 1989 roku. Najpierw pracował u ks. Zaniewskiego w Żupranach, pomagając doraźnie w duszpasterstwie w Oszmianie i Lidzie. Po objęciu parafii w Wornianach dojeżdżał także do Bystrzycy, gdzie wybudował kaplicę pw. św. Jana Chrzciciela oraz do Michaliszek. Parafia worniańska liczy obecnie ok. 2.500 wiernych, w 1932 roku prawie 6.000 .

Proboszcz Pikuła w 1996 roku został mianowany proboszczem w kościele św. Joachima w Kluszczanach, oddalonych o $60 \mathrm{~km}$ od Wornian. Tamtejszy kościół parafialny ufundował w 1875 roku Jan Korsak, przebudowanego w 1887 roku.

Dojeżdża także z posługą do Worony. Tamtejszy kościół św. Filemony, zamknięty przez władze, popadł w ruinę. Pozostały jedynie gołe ściany. Ks. Pikuła podjął się jego odbudowy. Poświęcony został dnia 6 XII 2004 roku przez biskupa Aleksandra Kaszkiewicza. W tej uroczystości wziął udział biskup pomocniczy z Grodna Antoni Dziemianko. Do tamtejszego kościoła uczęszcza ok. 700 wiernych ${ }^{94}$.

Parafia Wniebowzięcia NMP w Zdzięciole (obwód Grodno, rejon Zdzięcioł, diec. grodzieńska, dek. Zdzięcioł). Obecny kościół parafialny w Zdzięciole stoi na miejscu wcześniejszego drewnianego ufundowanego przez księcia Konstantego Ogińskiego (według tradycji), wojewodę kijowskiego, lub przez Kazimierza Jagiellończyka (inny przekaz), który potwierdził nadanie w 1493 roku. Barokowy kościół budowany był w latach 1624-1646 z fundacji księcia Kazimierza Sapiehy (1609-1656), pisarza Wielkiego Księstwa Litewskiego, marszałka nadwornego litewskiego. Jednonawowy kościół stanął pośrodku rynku miejskiego. Inwentarz z 1653 roku informuje, że we wnętrzu kościoła znajdowały się trzy ołtarze, główny o czterech kolumnach z obrazem Wniebowzięcia Matki Bożej oraz dwa boczne. Z akt wizytacji z 1668 roku wynika, że do tego czasu kościół nie został jeszcze konsekrowany. Dokonał jej w 1674 roku sufragan wileński Mikołaj Słupski ${ }^{95}$.

${ }^{93}$ Catalogus ecclesiarum et cleri archidioecesis vilnensis pro anno domini 1929, Vilnae 1929, s. 103-104.

${ }^{94}$ Relacja ks. Zdzisława Pikuły z 13 XII 2006 roku - Worniany (zb. aut.).

${ }^{95}$ M. Zgliński, Dla wygody y parady przybytku pańskiego. Rokokowa przebudowa Kościoła parafialnego $w$ Zdzięciole $w$ świetle pewnego inwentarza, „Przegląd Wschodni, t. 7, z. 4 (28) 
Przebudowany został po pożarze ${ }^{96} \mathrm{w}$ latach $1743-1751 \mathrm{w}$ stylu baroku wileńskiego wg projektu architekta Aleksandra Osikiewicza, kosztem Mikołaja Faustyna Radziwiłła i żony Barbary z Zawiszów ${ }^{97}$. Odbudowa nadała elewacji frontowej i wnętrzu kościoła, nowy, rokokowy kształt i stanowiła przykład tak zwanego wileńskiego baroku w jego prowincjonalnej odmianie, w porównaniu ze stołecznym Wilnem ${ }^{98}$.

Po II wojnie światowej nie udało się władzom komunistycznym zamknąć kościoła parafialnego. Jest świątynią jednonawową, nieprzerwanie czynną w okresie rządów komunistycznych do dziś. Od kwietnia 1946 roku do swej śmierci (12 III 1969) obsługiwał go ks. Jan Ignacy Wielkiewicz, salezjanin.

Zanim ks. Bernard Kaliński, który w 1989 roku wyjechał na Białoruś, został skierowany do Zdzięcioła, musiał stawić się z biskupem Tadeuszem Kondrusiewiczem u urzędnika ds. religii w Grodnie. Ten po długiej rozmowie wydał polecenie, aby ks. Bernard udał się do Zdzięcioła i czekał na dalsze dyspozycje. Do Zdzięcioła z ks. Kalińskim przybył ks. Józef Zaniewski, proboszcz w Żupranach. Na początek zamieszkał prywatnie w jednym pokoju przy ul. Lenina 23. Wyposażenie mieszkania było bardzo skromne: łóżko, stolik i krzesła ${ }^{99}$.

Tu w Zdzięciole po raz pierwszy od 50 lat odbyła się I Komunia św. dzieci. Sukienki otrzymały z Białegostoku. Przed nowym proboszczem stało wiele przedsięwzięć. Pierwszym była zmiana dotychczasowego tzw. komitetu kościelnego, składającego się z dwudziestu przedstawicieli parafii - $d w a d c a t k i$. Był on powoływany przez resort ds. religii. Zadaniem komitetu było zarządzanie funduszami parafii. Ofiary na tacę zbierali przedstawiciele komitetu, liczyli i wpłacali do banku. Księdzu co miesiąc wypłacali pensję. Komitet decydował o remontach, zakupach szat i sprzętów liturgicznych. Ks. Kalińskiemu udało się przeforsować do komitetu „swoich” ludzi. Po pewnym czasie taca trafiała już do proboszcza. Kapłan z Polski nie mógł być przewodniczącym komitetu ani wchodzić w jego skład.

Po objęciu parafii w Zdzięciole ksiądz proboszcz zauważył już w pierwszą niedzielę, że w kościele uczestniczą wierni w wieku średnim i starszym. Młodzieży i dzieci nie było prawie wcale. Dopiero po I Komunii pojawiły się dzieci. Do przyciągnięcia młodzieży do kościoła przyczyniły się z pewnością dwa wyjaz-

s. 1194-1196.

${ }^{96}$ Pożar wybuchł 4 VI 1743 roku o godz. 16.00. Pochłonął drewnianą zabudowę rynku oraz doszczętnie strawił świątynię wraz z jej wyposażeniem. Pozostały jedynie wypalone mury. Zgliński, Dla wygody y parady przybytku pańskiego. Rokokowa przebudowa Kościoła parafialnego w Zdzięciole, s. 1196-1197.

${ }^{97}$ Wprawdzie w lutym 1746 roku zmarł książę Mikołaj Faustyn, wdowa po nim, Barbara z Zawiszów łożyła nadal środki na dalszą odbudowę, planując uczynić z kościoła parafialnego rodzaj mauzoleum poświęconego pamięci męża, a po 1755 roku także pamięci zmarłego syna Jerzego. Powstały więc nagrobki z sercem Mikołaja Faustyna i Jerzego Radziwiłłów. Zgliński, Dla wygody y parady przybytku pańskiego. Rokokowa przebudowa Kościoła parafialnego w Zdzięciole, s. 1197-1198, 1203.

${ }^{98}$ Rąkowski, Ilustrowany przewodnik po zabytkach kultury na Białorusi, s. 284.

${ }^{99}$ Ks. Bernard Kaliński do ks. W. Żurka z 5 X 2006 roku - Lutomiersk (zb. aut.). 
dy młodzieży na spotkanie z Ojcem Świętym Janem Pawłem II, gdy pielgrzymował do Polski. Na spotkanie do Białegostoku zgłosiło się ponad 900 osób. Zorganizowanie tak dużej grupy wymagało niebagatelnych przygotowań ${ }^{100}$.

Na spotkanie z Ojcem św. w Częstochowie (spotkanie z młodzieżą) zgłosiło się ponad 400 osób. Należało młodzież przygotować do tego wyjazdu. Na specjalnych spotkaniach w kościele wyjaśniano podstawowe pojęcia dotyczące wiary, Kościoła, hierarchii, celu istnienia Kościoła i jego zadań. Spośród zgłoszonych 400 osób dojechało na spotkanie z papieżem ponad 100 osób. Warunkiem wyjazdu na spotkanie z Ojcem św. było nauczenie się na pamięć: Ojcze nasz i Zdrowaś Maryjo po polsku lub po rosyjsku.

Innym przejawem działalności duszpasterskiej była wizyta duszpasterska, tzw. kolęda. Tu w Zdzięciole, miasteczku powiatowym, na znacznym terenie zamieszkiwało ok. 12 tys. mieszkańców. Do parafii należało kilkanaście wiosek, a w późniejszym czasie doszły jeszcze dwie parafie w Dworcu i Rohatnej, więc kolęda pochłaniała dużo czasu - do Wielkiego Postu. W czasie takiej kolędy możliwe było zaprowadzenie rodzinom katolickim kartotek parafialnych. Okazało się, że nie było rażących zaniedbań. Około 70-80 \% rodzin żyło w sakramentalnych związkach małżeńskich, dzieci ochrzczone. Nieco gorzej było z I Komunią św. i sakramentem bierzmowania.

Gdy proboszcz udawał się z kolędą na wioski, zabierał ze sobą Najświętszy Sakrament. Po odwiedzeniu wszystkich rodzin danego dnia, chorzy i starsi gromadzili się w jednym lub kilku miejscach. Z pomocą księdza robili rachunek sumienia i odbywała się spowiedź. Niejednokrotnie była to pierwsza spowiedź od kilkudziesięciu lat, a po niej otrzymywali sakrament chorych i komunię świętą. I tak trwało przez przeszło miesiąc. Kolęda zajmowała cały dzień od godziny 9.00. Te odwiedziny w rodzinach budziły wiele wzruszenia. Od zakończenia II wojny światowej ks. Kaliński był pierwszym kapłanem odwiedzającym rodziny z wizytą duszpasterską. Niektórzy parafianie płakali ze wzruszenia. Przed dom wynosili dywan lub posypywali drogę żółtym piaskiem ${ }^{101}$.

Oddzielny rozdział to głoszenie Słowa Bożego w niedziele i święta. Słowo Boże głosił na temat 10 przykazań Bożych. W każdą niedzielę wyjaśniał jedno przykazanie. Następnie przeszedł do wyjaśniania 5 przykazań kościelnych, głównych prawd wiary, 7 sakramentów św., 5 warunków sakramentu pokuty, Składu Apostolskiego, Mszy św., sumienia i innych tematów.

Najbardziej pracochłonna okazała się spowiedź. Przed Mszą św. ksiądz był do dyspozycji najpóźniej 45 min. Tak praktykował w każdym kościele. Były momenty, że nie zdążył wszystkich wyspowiadać. Przy udzielaniu Komunii św. zdarzały się niespodzianki. Pewnego razu stary kościelny, widząc że do Komunii jest jeszcze sporo ludzi, a w puszce kończą się komunikanty, nachylił się i szeptem mówi: „Proszę księdza, w zakrystii są, dosypać”? Innym razem jakaś kobieta przystępu-

${ }^{100}$ Należało sporządzić listy po rosyjsku z danymi osobowymi oraz dołączyć zdjęcie. Nie brakowało trudności. Wystarczyło, że została jedna litera imienia lub nazwiska niezbyt mocno dobita i trzeba było przepisywać cały arkusz i jechać po raz drugi do Grodna oddalonego o $140 \mathrm{~km}$. Ks. Bernard Kaliński do ks. W. Żurka z 5 X 2006 roku - Lutomiersk (zb. aut.).

${ }^{101}$ Ks. Bernard Kaliński do ks. W. Żurka z 5 X 2006 roku - Lutomiersk (zb. aut.). 
jąc do Komunii św. trzymała w rękach może 3-letniego wnuczka. Zwróciła się do księdza mówiąc: „Dajte jemu, on kreszczon” 102.

Przez lata walki z Kościołem i wszystkimi przejawami życia religijnego ludzie powoli rezygnowali z niektórych przejawów tego życia. Zanikły kółka różańcowe chociaż różaniec był ich codzienną modlitwą. Najczęściej, gdy przychodzili do kościoła, przed rozpoczęciem Mszy św. większość modliła się na różańcu. Zanikły także nabożeństwa majowe odprawiane przy krzyżach przydrożnych. Udało się w krótkim czasie wznowić je, tak że w każdej wiosce gromadzili się wierni w miesiącach maryjnych na litanię loretańską. Pytani, dlaczego zrezygnowali ze śpiewania litanii w maju, odpowiadali, że jeszcze w latach czterdziestych ubiegłego stulecia gromadzili się przy krzyżu, ale młodzi ludzie z Komsomołu przeszkadzali.

Życzliwość tamtejszej ludności jest ogromna. Z okazji ślubu, chrzcin czy pogrzebu obdarowywali księdza poczęstunkiem (kiełbasa, słonina, masło, chleb, ogórki, jajka).

Na pożegnanie ks. Kalińskiego, po ostatniej Mszy św. parafianie w Zdzięciole usłali drogę kwiatami od ołtarza do samochodu przed kościołem. Ze Zdzięcioła ks. Kaliński udał się do parafii Żuprany, do ks. Józefa Zaniewskiego. Ponieważ w oddalonej o $12 \mathrm{~km}$ od Żupran Oszmianie został zwrócony wiernym kościół, więc tam było zapotrzebowanie większe na kapłana.

Na jego miejsce przybył w 1993 roku ks. Kazimierz Walczuk, który objął urząd proboszcza. Po nim przejął parafię w 2000 roku Kazimierz Murawa, który tam duszpasterzuje do dziś.

Parafia Świętych Piotra i Pawła w Żupranach (obwód Grodno, rejon Oszmiana, diec. grodzieńska). Jest to miejscowość na d rzeką Oszmianką. Kościół parafialny katolicki, niewiadomej erekcji, ufundował w połowie XVI w. Henryk Dauksza. Miasteczko Żuprany to dawna posiadłość Radziwiłłów, z których Bogusław, zmienił kościół pw. NMP Bolesnej i św. Piotra i Pawła na zbór kalwiński, a fundusze sobie przywłaszczył. Świątynia pozostawała w rękach kalwinów do 1646 roku. Przebudowana została w 1864 roku przez Adama Czapskiego ${ }^{103}$.

W 1981 roku ks. Józef Zaniewski został mianowany proboszczem w Żupranach. Jego ofiarna 9-letnia praca w parafii i otwartość na wszystkich zjednały mu serca wielu parafian. Pracy miał ogromnie dużo. Był jedynym kapłanem w tej okolicy. Najbardziej niepokoiło ówczesne władze jego zaangażowanie w duszpasterstwo dzieci i młodzieży, co też było przyczyną częstych kontroli czynników wyższych. Bardzo pomocna była wówczas u proboszcza świadomość solidarnego wsparcia

${ }^{102} \mathrm{~W}$ jednym domu 35 letni mężczyzna zapytał: „Kto był większy Lenin czy Chrystus”? Wielu maluchów na prośbę ich rodziców popisywało się znajomością pacierza po polsku. Ponieważ tamtejsi mieszkańcy przywiązywali wielką wagę do poświęceń, więc prawie w każdym domu proszono kapłana aby poświęcił spiżarkę z zapasami na zimę, a także kilka kurek, świnkę, a czasami i krowę, jeśli posiadali. Ks. Bernard Kaliński do ks. W. Żurka z 5 X 2006 roku - Lutomiersk (zb. aut.).

${ }^{103}$ Catalogus ecclesiarum et cleri archidioecesis vilnensis pro anno domini 1936, Vilnae 1936, s. 86; Stownik geograficzny Królestwa Polskiego i innych krajów stowiańskich, red. B. Chlebowski, t. 14, Warszawa 1895, s. 855. 
ze strony parafian. W tym początkowym okresie pomagali mu doraźnie salezjanie przyjeżdżający z Polski na zaproszenie ${ }^{104}$.

W sierpniu 1989 roku ks. Kazimierz Szoka wyjechał z Głoskowa by podjąć duszpasterstwo na terenie Związku Radzieckiego. Na prośbę ks. Józefa Zaniewskiego przybył do Żupran. Pomagał mu w parafii na miejscu i w sąsiedniej Oszmianie, gdzie już wówczas oddano jedną nawę kościoła, zamienionego na fabrykę wyrobów plastycznych. Obaj pracowali razem do końca stycznia 1990 roku. W połowie stycznia 1990 roku przybył z Głoskowa ks. Antoni Rafałko, a ks. Szoka przeniósł się do Radunia, gdzie duszpasterzował ks. Kazimierz Szaniawski, ksiądz diecezjalny ${ }^{105}$.

W 1981 roku bp Tadeusz Kondrusiewicz z Grodna, po otrzymaniu nominacji na administratora apostolskiego dla katolików obrządku łacińskiego europejskiej części Rosji z siedzibą w Moskwie, zabrał ze sobą ks. Józefa Zaniewskiego z Żupran. Niełatwe było rozstanie z parafią i wiernymi, gdzie ks. Józef pozostawił tyle poświęcenia, trudów, wyrzeczeń i serca. Po nim probostwo w Żupranach przejął ks. Antoni Rafałko.

Po nim proboszczował tam kolejne dziewięć lat - do 1990 roku - ks. Krzysztof Cabała. Po jego przeniesieniu do Moskwy proboszczem został ks. Marek Poniewierski (1999- II 2002), ks. Aleksander Jaszewski (II 2002-X 2002). Obecnie proboszczem w Żupranach od 20 X 2002 roku jest ks. Wojciech Biskiewicz, uprzednio sekretarz w Inspektoracie Okręgu Wschodniego w Moskwie ${ }^{106}$.

Przejściowo pracowali salezjanie w Bierdowce (1992-1999), Lidzie (19901998), Oszmianie (1990-1995), Murowanej Oszmiance (1992-1996), Krasnem (1992-1993), Krupowie (1991-1998) i Rohotnej (1993-1998) oraz Wołkowysku (1992-1993).

Parafia Niepokalanego Poczęcia NMP w Lidzie na Słobódce (obwód Grodno, rejon Lida, diec. grodzieńska). W 1989 roku przyjechał do parafii Białogruda w charakterze wikariusza ks. Kazimierz Szoka, salezjanin. Dojeżdżał także z posługą duszpasterską do oddalonej o $90 \mathrm{~km}$ Lidy, gdzie proboszczem był ks. Kazimierz Szaniawski. W Białogrudzie w 1938 roku została wybudowana drewniana kaplica, która w okresie powojennym nie została nigdy zamknięta. Pewnego razu przyjechał do Białogrudy z posługą pewien franciszkanin, który krzyczał z ambony, że ks. Szoka dojeżdża do Lidy, a przecież mógłby tam zamieszkać na stałe i zająć się miejscowym duszpasterstwem. Ostatecznie ks. Szoka przyjechał do Lidy i prowadził przez 3 lata tamtejsze duszpasterstwo, na co otrzymał stosowne zezwolenie władz na pobyt i pracę $e^{107}$.

${ }^{104}$ Weder, Znaki nadziei, s. 48.

${ }^{105}$ Obaj obsługiwali trzy parafie: w Raduniu (30 km od Lidy), Lidzie i Białogrudzie (20 km od Lidy) do końca marca 1990 roku. Od końca marca 1990 roku ks. Szoka zamieszkał w Lidzie na Słobódce. Ks. Kazimierz Szoka do ks. W. Żurka z 15 X 2006 roku - Jaciążek (zb. aut.).

${ }^{106}$ Relacja ks. Wojciecha Biskiewicza z 18 XII 2006 roku - Żuprany (zb. aut.).

${ }^{107}$ Urzędnik ds.wyznań w obecności bpa Tadeusza Kondrusiewicza proponował rejestrację ks. Szoki jako wikariusza proboszcza raduńskiego. Ks. Szoka stwierdził, że może przyjąć tzw. sprawkę, ale jako proboszcz w Lidzie. Po pewnych perypetiach, urzędnik obawiając się zgromadzonych pa- 
Rozpoczął ks. Kazimierz od budowy nowej plebanii, gdyż dawnej władze nie oddały. Plac pod budowę przydzielono bezpłatnie. W trakcie budowy plebanii, w połowie października 1992 roku rozpoczął budowę kościoła w dzielnicy Lidy-Słobódka. W duszpasterstwie w Lidzie pomagał ks. Kazimierzowi jego brat Stanisław - salezjanin, który w sierpniu 1991 roku przybył do Lidy. Miał wtedy 58 lat. W lipcu 1992 roku doznał wylewu, a 28 VII 1993 roku zmarł podczas rekolekcji kapłańskich w Szczuczynie. W tym czasie wikariuszem u ks. Szoki byli: ks. Igor Łaszuk, ks. Edward Mackiewicz (1 rok - do września 1993 roku), ks. Jan Romanowicz, ks. Józef Bogusz, ks. Kazimierz Murawa, ks. Tomasz Piasecki, ks. Grzegorz Głowienka, ks. Dariusz Ludera, ks. Andrzej Obuchowski, ks. Wiesław Dąbrowski (senior) - od sierpnia 1993 do października 1994. Ks. Wiesław przeszedł następnie na proboszcza do Nowojelni i Dworca. Pomagał także w duszpasterstwie ks. Stanisław Lugowski ${ }^{108}$. W parafii pracowały Siostry Notre Dame jako katechetki i organistka. Budowa kościoła w Lidzie trwała do 1998 roku. Przez krótki czas ks. Szoka myślał o przejściu do diecezji. W międzyczasie postarał się o przydział przez władze miejscowe działki pod budowę nowego kościoła w Lidzie na osiedlu Posiołek Industralny. Ks. Szoka oceniając swój stan zdrowia i wiek postanowił powrócić do Polski. W 1998 roku duszpasterstwo w Lidzie salezjanie przekazali klerowi diecezjalnemu ${ }^{109}$.

Parafia pw. Trójcy Przenajświętszej w Bierdowce (obwód Grodno, diec. grodzieńska). Miejscowość oddalona $18 \mathrm{~km}$ od Lidy. Dojeżdżał tam wikariusz z kościoła w Oszmianie a następnie w Lidzie - ks. Stanisław Ługowski, który w 1992 roku odzyskał kościół w Bierdowce i rozpoczął jego restaurację. Na ten czas zamieszkał ks. Ługowski w Bierdowce. Tam duszpasterzował trzy lata, skąd przeszedł na placówkę do Mińska. Przez kilka miesięcy pracował tam (do 9 XII 1997) ks. Józef Bogusz. Kiedy salezjanie oddali w 1998 roku parafię Niepokalanego Poczęcia NMP w Lidzie, w 1999 roku oddali także parafię w Bierdowce ${ }^{110}$.

Parafia pw. Trójcy Przenajświętszej w Krupowie (obwód Grodno, diec. grodzieńska). Parafię w Krupowie, oddalonym o 8 km od Lidy, obsługiwał miejscowy ksiądz Stanisław Pacyna. Po jego odejściu z Krupowa duszpasterstwo przejęli salezjanie z Lidy. Ponieważ dojazd był trudny, biskup zdecydował o ustanowieniu tam proboszcza. Pierwszym proboszczem przybyłym tam w 1991 roku

rafian z Lidy, mianował ks. Szokę proboszczem w Lidzie. Ks. Kazimierz Szoka do ks. W. Żurka z 15 X 2006 roku - Jaciążek (zb. aut.).

${ }^{108}$ Z Lidy ks. Ługowski został skierowany do Oszmiany. Będąc w Oszmianie od lipca 1993 roku rozpoczął obsługiwać kościół w Bierdowce, gdzie od kwietnia 1994 roku zamieszkał. Ks. Kazimierz Szoka do ks. W. Żurka z 15 X 2006 roku - Jaciążek (zb. aut.).

${ }^{109}$ Po upływie półtora roku przybył Radca Generalny na wizytację Okręgu Wschodniego. Dał księdzu Kazimierzowi możliwość przejścia do diecezji lub powrotu do Polski. Ks. Kazimierz Szoka do ks. W. Żurka z 15 X 2006 roku - Jaciążek (zb. aut.).

${ }^{110}$ Relacja ks. Stanisława Ługowskiego z 20 II 2006 roku - Przemyślany i relacja ks. Zdzisława Wedera z 8 XI 2006 roku - Kraków (zb. aut.). 
z Polski był ks. Wacław Stefanowicz. Był on po operacji rakowej, stąd pracował tylko do lutego 1992 roku. Następnie rodzina zabrała go do Wilna, gdzie zmarł w marcu 1992 roku i został pochowany w Wilnie na Ponarach. Po nim probostwo w Kurpowie objął ks. Franciszek Rosłan, pomocnik-wikariusz ks. Antoniego Rafałko w Oszmianie. Ksiądz Franciszek odnowił wnętrze kościoła i plebanii. Po nim probostwo przejął 25 VIII 1996 roku ks. Józef Bogusz (do 20 XI 1997). W 1998 roku salezjanie oddali duszpasterstwo w Krupowie klerowi diecezjalne$\mathrm{mu}^{111}$.

Parafia Najświętszego Imienia Maryi w Murowanej Oszmiance (obwód Grodno, rejon Oszmiana, diec. grodzieńska). Granice pierwszej parafii zostały określone w 1790 roku przez Ignacego Ważyńskiego. Parafię ufundował w 1841 roku Marcin Ważyński. W 1874 roku świątynia została przebudowana przez Karola Ważyńskiego ${ }^{112}$.

Po odzyskaniu kościoła jako pierwszy duszpasterstwo podjął tam ks. Kazimierz Walczuk, potem ks. Jan Romanowicz, który z Murowanej Oszmianki przeszedł do Żupran.

Parafia Świętego Michała Archanioła w Oszmianie (obwód Grodno, rejon Oszmiana, diec. grodzieńska). Kościół parafialny ufundowany w 1387 roku przez króla Władysława Jagiełłę. Odbudowany ze zniszczeń w XVII w., następnie gruntownie przebudowany w latach 1900-1906. Zamknięty w 1950 roku przez władze komunistyczne i przerobiony na fabrykę. Zwrócony katolikom w 1989 roku po czterdziestu latach, odbudowany i wyremontowany ${ }^{113}$.

W przeszłości znajdowała się w kościele tablica upamiętniająca ok. 500 cywilnych mieszkańców Oszmiany, w tym kobiety i dzieci, które schroniły się w kościele podczas powstania listopadowego, podpalonym przez carskich żołnierzy dnia 15 IV 1831 roku. W 1992 roku odsłonięto w kościele tablicę upamiętniającą wydarzenia z ostatniej wojny światowej - żołnierzy 8 . brygady AK ,Tara”.

Do ks. Józefa Zaniewskiego pracującego w Żupranach przyjeżdżali wierni z Oszmiany z prośbą, by objął opieką duszpasterską tamtejszych wiernych i kościół. Ofiacjalnie kościół został zwrócony, ale wciąż mieściła się w nim fabryka. Wiernym udało się odzyskać w 1991 roku jedną boczną - lewą nawę świątyni dla sprawowania kultu. Odzyskaną część świątyni oddzielono ścianą o wysokości 2-3 m od reszty zajmowanej przez fabrykę. Mszę św. odprawiano o godz. 12.00, gdy była przerwa obiadowa na pierwszej zmianie i o godz. 19.00, w czasie przerwy obiadowej na drugiej zmianie. Był to odpowiedni czas na liturgię gdyż maszyny nie pracowały. Gdy kończyła się przerwa, huk pracujących maszyn wzmagał się do tego stopnia, że tylko najbliżsi przy ołtarzu słyszeli słowa księdza. Zdarzały

${ }^{111}$ Wykaz placówek $i$ współbraci polskich prowincji Towarzystwa Salezjańskiego 1992-93, red. S. Kuciński, Kraków 1991, s. 112. Relacja ks. Franciszka Rosłana 20 II 2006 roku - Przemyślany (zb. aut.); Ks. Kazimierz Szoka do ks. W. Żurka z 15 X 2006 roku- Jaciążek (zb. aut.).

${ }^{112}$ Catalogus ecclesiarum et cleri archidioecesis vilnensis pro anno domini 1936, Vilnae 1936, s. 84 .

113 Tamże, s. 84; Rąkowski, Ilustrowany przewodnik po zabytkach kultury na Białorusi, s.178. 
się przypadki, że sprawowano liturgię mszalną w czasie pracy maszyn fabrycznych, gdyż odprawiano dwie Msze św. jedną po drugiej. Gdy zgromadzeni wierni śpiewali pieśni i modlili się w odzyskanej części kościoła, pracownicy podglądali stojąc na podwyższeniu. Tak przez pewien czas trwała symbioza sprawowanej liturgii świętej i produkcji fabrycznej. W tej sytuacji zarząd fabryki począł się wycofywać, oddając stopniowo zajmowane powierzchnie aż doczekano się oddania całego kościoła. Wybudowany w pobliżu kościoła-fabryki biurowiec dziś służy na mieszkanie dla duszpasterzy i sióstr zaangażowanych w parafii ${ }^{114}$.

Po odzyskaniu kościoła w Oszmianie w 1989 roku pierwszym proboszczem został ks. Józef Zaniewski, z rezydencją w Żupranach. Przyjeżdżający z Polski salezjanie pomagali mu zarówno w Oszmianie jak i Żupranach. „Zamęczał” w Oszmianie ogrom penitentów. Wierni ciągnęli tabunami. Spowiadano w dni powszednie tygodnia godzinami. Kilkunastometrowe kolejki jakby wcale nie topniały, gdyż wciąż dochodzili nowi. W $90 \%$ spowiadano w Oszmianie po polsku, a tylko w niektórych po rosyjsku. Któregoś dnia przyjechał z pomocą ks. Ignacy Ryndzionek. Kiedy ponowił przyjazd za rok, zapytał: czy tamte kolejki z ubiegłego roku już wyspowiadaliście? Duża liczba zamawianych intencji mszalnych zmuszała duszpasterzy do binowania a nawet trinowania. Zamawiający Msze św. przynosili ze sobą tzw. chabory, aby po Mszy św. podziękować księdzu w zakrystii za odprawioną Mszę św. i obowiązkowo ucałować rękęę15.

W Oszmianie księża dowiedzieli się o reakcji nauczycieli w szkole gdy w mieście pojawili się kapłani katoliccy. Chodzili zawsze w sutannach: do kościoła, sklepu, na pocztę, do urzędu. Dzieci, które po raz pierwszy w życiu widziały księdza, pytały w szkole nauczycielki: kto jest ten w długim czarnym płaszczu? Nauczycielka odpowiedziała: to czarownik, nie zbliżajcie się do niego.

Zbliżały się święta Bożego Narodzenia 1991 roku i związana z tym atmosfera radości. Parafianie przygotowywali odzyskaną na razie lewą nawę kościoła. Duszpasterze pomyśleli nawet o próbie śpiewu kolęd, obawiając się by pierwsza pasterka po przeszło 40 latach nie pozostawiła jakiegoś niedosytu. Stanęło na tym, że nie będzie próby śpiewu, a parafianom da się możliwość spontanicznego wyśpiewania swojej radości i wdzięczności Bogu. Jakież było zaskoczenie, gdy o północy zaintonowano „Wśród nocnej ciszy”, a potężny śpiew ludu przyprawiał o drżenie mury kościoła. Wyśpiewali wszystkie zwrotki kolędy z pamięci. W tym śpiewie wyrażała się przeżywana przez tamtejszych katolików wiara, która na nowo odżyła ${ }^{116}$.

Biskup Tadeusz Kondrusiewicz wyjeżdżając do Moskwy zabrał z Żupran ks. Józefa Zaniewskiego i mianował go w 1991 roku proboszczem w kościele na ul. Małej Gruzińskiej 27 w Moskwie. Probostwo w Oszmianie objął po nim ks. Antoni Rafałko. Dziekanem oszmiańskim był ks. Henryk Boguszewski, proboszcz

${ }^{114}$ Ks. Bernard Kaliński do ks. W. Żurka z 5 X 2006 roku - Lutomiersk (zb. aut.).

${ }^{115}$ Te ucałowania w rękę duszpasterze stopniowo wyciszali, gdyż dawały się we znaki, zwłaszcza wtedy, gdy w zakrystii zjawiła się liczna rodzina i wszyscy podchodzili aby się przywitać i ucałować rękę kapłana. Ks. Bernard Kaliński do ks. W. Żurka z 5 X 2006 roku - Lutomiersk (zb. aut.).

${ }^{116}$ Weder, Znaki nadziei, s. 17-18. 
w Borunach. Ks. Rafałko, jako proboszcz, odrestaurował wieżę kościoła z krzyżami. Gdy doznał paraliżu, parafię oszmiańską przejął tymczasowo ks. Franciszek Rosłan, przybyły natychmiast z Głubczyc, a następnie także z w prowincji pilskiej przybyły ks. Benedykt Wisiński. Wikariuszami w Oszmianie byli: ks. Jacek Żurawski, ks. Jan Niemiec (1994-1995) ${ }^{117}$, ks. Stanisław Ługowski.

Do Oszmiany przyjeżdżał na początku lat 90 . ubiegłego stulecia na zaproszenie ks. Antoni Murziński ${ }^{118}$ z pilskiej Prowincji św. Wojciecha. Po miesiącu pracy wracał do Polski i przyjeżdżał ponownie na kolejne zaproszenie. W sumie w Oszmianie ks. Murziński pracował trzy miesiące. Po odejściu z Oszmiany ks. Wisińskiego tamtejszą parafię przejęli księża diecezjalni ${ }^{119}$.

Parafia Świętych Aniołów Stróżów w Rohotnej (obwód Grodno, diec. grodzieńska). Kościół w Rohotnej ufundował ok. 1400 roku Bartłomiej de Rohotna. Parafia została erygowana w 1840 roku. W 1867 roku świątynię przejęli prawosławni, katolicy odzyskali ją w 1918 roku $^{120}$.

W powojennych latach rządów komunistów 1947-1989 kościół był zamknięty decyzją władz sowieckich i służył jako magazyn. Odzyskany przez katolików w 1991 roku. W latach 1991-1993 proboszczem parafii był ks. Bernard Kaliński. Zorganizował on wówczas w 1992 roku w parafii I Komunię św., pierwszą od ponad pół wieku. Pierwszą Komunię dzieci organizowano głównie w sierpniu: w 1996 roku - 24 dzieci; 1997 - 11; 1998 - 25.

Z polecenia ordynariusza grodzieńskiego, bpa Aleksandra Kaszkiewicza, dnia 22 XI 1995 roku ks. Wiesław Dąbrowski (senior) objął parafię w Rohotnej, jako już trzecią - po Nowojelni i Dworcu. Pracujący tu proboszcz wyjechał do Polski. Jak wszędzie na tych terenach wszystko należało rozpoczynać od nowa. Cieszyła duża frekwencja wiernych, także prawosławnych, w czasie rekolekcji wygłoszo-

${ }^{117}$ Ks. Niemiec Jan, ur. w 1950 roku, święcenia kapłańskie otrzymał 6 X 1972 roku w Rumi. W 1994 roku wyjechał do pracy na Wschód. Zatrzymał się w Oszmianie, skąd w następnym roku został wyrzucony przez władze białoruskie. Przybył do Korostyszewa, na Ukrainę, by w kwietniu 1996 roku powrócić na Białoruś, do parafii Boruny. Relacja ks. Jana Niemca z 20 II 2006 roku Przemyślany (zb. aut.).

${ }^{118}$ Ks. Murziński Antoni, ur. 15 III 1944 roku w miejscowości Milewskie. Nowicjat odbył 1961/1962 w Czerwińsku, święcenia kapłańskie 6 X 1972 roku w Rumi. W grudniu 1990 roku wyjechał z Debrzna (prowincja pilska) na Wschód. Wraz z ks. Stanisławem Ługowskim i ks. Janem Hibnerem mieli się przygotowywać do funkcji kapelanów Sióstr Matki Teresy z Kalkuty, w ich domach w Petersburgu, Moskwie i Nowosybirsku. Tymczasem w listopadzie 1990 roku nuncjuszem europejskiej części ZSRR został w Moskwie abp Francesco Colasuono, a księża, którzy przybyli z nuncjuszem, objęli planowane dla trzech salezjanów funkcje kapelanów w domach Sióstr Matki Teresy. Gdy plan przepadł, wówczas inspektor polskiej prowincji św. Wojciecha, ks. Stanisław Skopiak, załatwiwszy ks. Antoniemu zaproszenie na Białoruś, skierował go do Zdzięcioła. Gdy okazało się na miejscu, że ta placówka jest obsadzona, ks. Antoni przybył do ks. Rafałko do Oszmiany i tam, z przerwami na wyjazdy do Polski, pracował przez 3 miesiące. Relacja ks. Antoniego Murzińskiego z 20 II 2006 roku - Przemyślany (zb. aut.).

${ }^{119}$ Relacja ks. Stanisława Ługowskiego z 20 II 2006 roku - Przemyślany (zb. aut.).

${ }^{120}$ Catalogus ecclesiarum et cleri archidioecessis vilnensis pro anno domini 1936, Vilnae 1936, s. 126-127. 
nych tam w marcu 1997 roku przez ks. Stanisława Szmidta z Łodzi. Udało się także zgromadzić sporą gromadkę dzieci. Ks. Wiesław wykorzystywał każdą okazję dla przeprowadzenia katechezy. Zachęcał nauki katechizmu i pacierza konkursami z symboliczną nagrodą ${ }^{121}$.

Tamtejsza społeczność przeżywała wyjątkowy dzień, gdy dnia 9 VI 1996 roku powitano figurę MB Róży Mistycznej, która nawiedziła rodziny katolickie parafii.

Dnia 31 VII 1998 roku biskup grodzieński mianował wikariusza parafii Przemienienia Pańskiego w Nowogródku, ks. Michała Steckiewicza, administratorem w Rohotnej, z tymczasowym obsługiwaniem Starojelni. Ostatecznie przejęcie parafii przez nowego administratora nastąpiło 9 sierpnia tego roku $\mathrm{w}$ obecności biskupa-nominata Antoniego Dziemianko ${ }^{122}$.

$\mathrm{Na}$ terenie Republiki Białorusi, także na Ukrainie, obowiązuje w dalszym ciągu prawo sowieckie w stosunku do Kościoła katolickiego. Każdy proboszcz i duszpasterz musi otrzymać tzw. sprawkę - pozwolenie na sprawowanie czynności duszpasterskich na terenie wyznaczonej parafii, i tylko tej.

Dnia 18 III 2003 roku przedstawiciel ds. religii poinformował kapłanów przybyłych z innych krajów do pracy na Białorusi, w obecności obydwu biskupów (Aleksandra Kaszkiewicza i Antoniego Dziemianko), że za każdym razem należy uzyskać za pośrednictwem Kurii pozwolenie na czynności duszpasterskie w innej parafii. To bardzo utrudnia wzajemną pomoc w sąsiednich parafiach, jak np. pomoc w spowiedzi, głoszeniu kazań, zastępstw, udział w odpustach, głoszenie kazań rekolekcyjnych i w wielu innych inicjatywach duszpasterskich.

Jako uzasadnienie władze podają, że każdy kapłan jest zarejestrowany w danej parafii i tylko w niej może duszpasterzować. Jeżeli proboszcz planuje zaprosić kapłana (np. z Polski), zobowiązany jest na trzy miesiące wcześniej zgłosić ten fakt przez Kurię Diecezjalną, a ta z kolei do odnośnych władz w Mińsku. A jak postąpić w przypadku, gdy przybędzie pielgrzymka autokarowa z kapłanem, są przejazdem i chcą odprawić Mszę św., tym bardziej że każdy kapłan odprawia codziennie Mszę św.? Odpowiedź przestawiciela władz była jednoznaczna - nie wolno. Kara za przekroczenie tego prawa wynosi 200 minimalnych pensji miesięcznych.

\section{UKRAIŃSKA SOCJALISTYCZNA REPUBLIKA RADZIECKA - UKRAINA}

\section{a) Sowiecka Ukraina}

Po 1945 roku domy salezjańskiej prowincji św. Jacka leżące na terenie archidiecezji lwowskiej uległy całkowitej likwidacji. Żaden z pracujących salezjanów nie pozostał na terenie Ukraińskiej SRR. Możliwość podjęcia pracy przez salezjanów na wspomnianych terenach nadarzyła się kilkanaście lat po zakończeniu II wojny światowej.

\footnotetext{
${ }^{121}$ S. Szmidt, Rekolekcje białoruskie, s. 16.

${ }^{122}$ APN, Kronika parafii Nowojelnia - Dworzec, t. 1, s. 85, 86.
} 
Odpowiadając na prośbę biskupa Julijonasa Stepanowičiusa z Wilna, jesienią 1958 roku proboszcz w Ławaryszkach, ks. Tadeusz Hoppe, zdecydował się podjąć pracę duszpasterską w dalekiej Odessie nad Morzem Czarnym, w diecezji tyraspolskiej. Wyjeżdżał za pozwoleniem władz kościelnych i państwowych. Już na drugi dzień po przybyciu na miejsce, dnia 8 XII 1958 roku oznajmił tamtejszym wiernym, że pozostanie u nich do swojej śmierci. Słowa dotrzymał. Zmarł 10 XI 2003 roku w Odessie, po 45 latach pracy w kościele św. Piotra, tzw. profrancuskim $^{123}$.

Prokatedra pw. Wniebowzięcia NMP w Odessie pozostawała w tym czasie zamknięta od 1949 r. zamieniona na obiekt sportowy. Zasięg parafii odeskiej św. Piotra obejmował miasto Odessę i cztery województwa: Chersoń, Dniepropietrowsk, Mikołajów i Kijów.

Przez siedem i pół roku ks. Hoppe dojeżdżał co miesiąc z Odessy do Kijowa, na dzielnicę Światoszyn, gdzie dzięki jego zabiegom i zaangażowaniu tamtejszych katolików władze zezwoliły na zarejestrowanie „Domu modlitwy”, który stał się zaczątkiem ośrodka duszpasterskiego. W 1980 roku przybył do Kijowa na stałe i podjął duszpasterstwo o. Jan Krapan z Łotwy. Dnia 14 II 1981 roku duszpasterstwo w Kijowie przejęli Ojcowie Karmelici. Także Siostry Karmelitanki otworzyły tam swój klasztor.

Po śmierci ks. Bronisława Chodanionka w Kiszyniowie († 25 XI 1973) ks. Hoppe dojeżdżał również do stolicy Mołdawskiej SRR. Jeździł nocnym pociągiem, by nazajutrz od poranka następnego dnia służyć wiernym. Dojazdy do Kiszyniowa zakończyły się z chwilą przybycia tam w 1974 roku neoprezbitera ks. Władysława Zawalniuka ${ }^{124}$.

Jakie można wyróżnić formy duszpasterstwa ks. Hoppe w Odessie i okolicy?

${ }^{123}$ Kościół pw. św. Piotra zbudowany został w 1913 roku głównie dla katolików francuskich miasta Odessy. Zamknięty przez władze sowieckie, tamtejsi katolicy odzyskali go w 1947 r. Od tej pory służył nieprzerwanie dla katolików 15 narodowości i był jedynym czynnym kościołem katolickim we wschodniej części Ukraińskiej SRR.

${ }^{124}$ Ks. Zawalniuk Władysław, s. Mateusza i Anny, ur. 8 VI 1949 roku w Murafie, wcześniej Żdanowo w obwodzie Winnica w Ukraińskiej SRR (dziś diec. kamieniecko-podolska). Po ukończeniu szkoły średniej w Murafie, w 1965 roku wyjechał do Rygi z zamiarem wstąpienia do seminarium. Pracował fizycznie na budowie i uczył się łaciny. W 1969 roku został przyjęty do seminarium, wyświęcony 26 V 1974 roku w Rydze przez bpa Juliansa Vaivodsa. Jako neoprezbiter został skierowany do Kiszyniowa - stolicy Mołdawskiej SRR, jako duszpasterz ok. 15 tys. katolików, głównie narodowości polskiej i niemieckiej. Pozbawiony rejestracji, w styczniu 1980 roku został usunięty z Mołdawskiej Republiki Radzieckiej. Pracował na Łotwie (parafia Varklany). Tam napadnięty i zraniony, celowo został umieszczony w szpitalu psychiatrycznym w Dźwińsku (Daugavpils). Opuścił szpital na odpowiedzialność lekarza Rosjanina. Uciekając przed KGB ks. Władysław pracował konspiracyjnie jako duszpasterz w Kazachstanie: Celinogrodzie, Kokczetawie, Krasnoarmiejsku, Pawłodarze i Krasnojarsku na Syberii. Wreszcie powrócił na Łotwę i pracował jako administrator parafii: Lenas, Aispute, Venspils i Kuldzige w dek. Liepaja. W sierpniu 1985 roku rozpoczął pracę w parafii Głębokie w arch. wileńskiej na Białorusi. Tu doprowadził do reaktywowania kilku okolicznych parafii, zamkniętych po wojnie przez władze sowieckie, i do odzyskania kilku kościołów. W 1988 roku rozpoczął duszpasterstwo także w Mińsku, dokąd przeniósł się w 1990 roku na stałe jako proboszcz kościoła św. Szymona i Heleny, odzyskanego przez wiernych. R. Dzwonkowski, 
Władze komunistyczne nie zezwalały na drukowanie książek religijnych, modlitewników i książeczek do nabożeństwa. W tej sytuacji ks. Hoppe zapoczątkował książeczki „od ręki”. Wierni pisali ręcznie modlitwy i pieśni na kartkach małego formatu, następnie partiami zszywali je i w ten sposób powstawały książeczki do nabożeństwa liczące nawet ponad 800 stron. Przepisywane pieśni do modlitewników posiadały jeszcze tzw. dodatek odeski, zwrotki lokalnego autorstwa.

Chrztu świętego udzielał proboszcz w świątyni, częściej prywatnie w mieszkaniach.

W przypadku pogrzebu, gdy władze nie zezwoliły na udział kapłana w liturgii pogrzebowej, lub z innych względów rodzinnych kapłan nie przewodniczył liturgii pogrzebowej, proboszcz przez zaufaną osobę posyłał w pudełku po zapałkach poświęconą ziemię, którą wsypywano przed złożeniem trumny do mogiły a to zastępowało formę poświęcenia grobu. Zdarzało się, że do odleglejszych okolic ksiądz poświęconą ziemię posyłał w liście pocztowym. Przychodzili także w ciągu roku parafianie prosząc o poświęcenie ziemi, którą posypywali groby bliskich. W przypadku pogrzebu ludzi będących za życia na eksponowanych stanowiskach lub ich krewnych, ks. Hoppe odprawiał liturgię pogrzebową wcześniej prywatnie, przed oficjalnym ceremoniałem państwowym. W ostatni poniedziałek każdego miesiąca sprawowana była w kościele Msza św. za zmarłych w minionym miesiąca, przy katafalku i świecach, a po soborze Watykańskim II bez katafalku, a świece i znicze ustawione były na rozłożonym na środku świątyni kirze.

Ks. Hoppe dbał, by wierni spowiadali się często. Na pierwszy czwartek, piątek i sobotę miesiąca wszyscy parafianie niejako mieli obowiązek przystąpić do spowiedzi i Komunii św. W niedzielę spowiadał tylko przyjezdnych, tłumacząc miejscowym aby spowiadali się w inne dni, gdyż są na miejscu. Przed Mszą św. poranną i wieczorną był do dyspozycji w konfesjonale godzinę wcześniej. Nie rozpoczynał liturgii mszalnej czy nabożeństwa liturgicznego o wyznaczonej godzinie, zanim nie wyspowiadał wszystkich oczekujących. Chorym komunię św. przynosiły do domu osoby zaufane. Na pierwszy piątek proboszcz przybywał osobiście, by chorzy mogli skorzystać z sakramentu pokuty ${ }^{125}$.

Ks. Hoppe nie zaniedbywał chorych, samotnych, biednych, którzy potrzebowali pomocy materialnej. Parafianka Sabina Pilecka udawała się do takich osób, gotowała im posiłki, karmiła, robiła zakupy, sprzątała. Od proboszcza każdego miesiąca przynosiła im pomoc finansową. Nazywana była przez nich „Aniołem Stróżem chorych".

Niewiasty do Komunii św. obowiązkowo szły z nakryciem głowy. Po Komunii św. odprawiano wspólnie dziękczynienie, które polegało na głośnym odmówieniu kilku modlitw dziękczynnych.

Od połowy lat osiemdziesiątych ubiegłego stulecia salezjanie południowej prowincji św. Jacka wyjeżdżali turystycznie do Odessy, z pomocą ks. Hoppe. Należeli do nich ks. Kazimierz Szydełko, ks. Piotr Solich, ks. Stanisław Żak, ks.

Leksykon duchowieństwa polskiego represjonowanego w ZSRR 1939-1988, Lublin 2003, s. 665$-667$.

${ }^{125}$ W. W. Żurek, Działalność duszpasterska ks. Tadeusza Hoppe w Odessie, w: Polacy na Krymie, red. W. Walewander, Lublin 2004, s. 229-232. 
Joachim Jasita. Niektórym z wymienionych udało się zatrzymać dłużej lub pracują tam do dziś (ks. Jasita). Inni przenieśli się do sąsiednich państw, m. in. na Białoruś, do Rosji.

Także na Ukrainę Zachodnią udawali się polscy salezjanie, których rodzice pochodzili z terenów wschodnich II Rzeczypospolitej. Należeli do nich ks. Tadeusz Pater, ks. Krzysztof Pryputniewicz, ks. Edward Mazur. Ten ostatni przejeżdżał „turystycznie” całą Ukrainę, od Lwowa przez Kijów po Odessę, począwszy od 1964 roku i tak przez dwadzieścia lat w różnych odstępach czasu wyruszał na Wschód.

\section{b) Salezjanie na Ukrainie}

Na ziemiach wschodnich II Rzeczypospolitej, które mocą układu jałtańskiego w 1945 roku przeszły do Związku Radzieckiego i powiększyły terytorialnie Ukraińską Socjalistyczną Republikę Radziecką, w zasadzie prawosławia nie było, jedynie Cerkiew greckokatolicka, która w hierarchii i administracji kościelnej podlegała Stolicy Apostolskiej. Po wysiedleniu przymusowym Polaków w 1945 roku na Ziemie Zachodnie i po zasiedleniu tych ziem przesiedlonymi Ukraińcami, częściowo Łemkami, stalinowska Rosja całkowicie zlikwidowała Cerkiew greckokatolicą, a ustawowo wprowadziła „kościół narodowy”, uzależniony od władz państwowych - prawosławie. Religią panującą na mocy "synodu lwowskiego" z 1946 roku, który odbył się pod presją władz komunistycznych u św. Jura we Lwowie, miało być wyłącznie prawosławie. Niektóre kościoły grekokatolików zamieniono na cerkwie prawosławne, a większość z nich przeznaczono na pomieszczenia użytkowe, często niegodne miejsca poświęconego.

Mimo tak ostrych restrykcji władz komunistycznych, we Lwowie swoje funkcje kościoła katolickiego pełniły nieprzerwanie katedra łacińska i franciszkański kościół św. Antoniego przy ul. Łyczakowskiej. Były to Domy Modlitwy dla katolików (także grekokatolików) nie tylko miasta wojewódzkiego ale bliższej i dalszej okolicy. Przez cały okres panowania komunizmu pozostało u tamtejszych wiernych to przeświadczenie o istnieniu żywego Kościoła wyznawców Chrystusa, Kościoła katakumbowego, żyjącego w podziemiu i w sercach ludzkich.

Niezależnie od wspomnianych trudności praca duszpasterska we Lwowie była w dostępny sposób kontynuowana. Aby wspomóc podeszłego w latach franciszkanina, o. Rafała Kiernickiego z katedry (proboszcz od 1948 roku, od stycznia 1991 roku biskup pomocniczy we Lwowie) przyjeżdżali kapłani z Polski, bądź miejscowi księża wyświęceni w Rydze, jednym z dwóch seminariów duchownych funkcjonujących w okresie komunizmu, dla całego Związku Radzieckiego.

Tak było przez pół wieku. Przez te lata na gruncie wyznania greckokatolickiego wzrastało nowe pokolenie prawosławia. Wraz z utworzeniem państwa Ukrainy, po roku 1991 odżyła Cerkiew greckokatolicka, głównie na Ukrainie Zachodniej, na obszarze dawnej Małopolski Wschodniej. Nierzadko dochodzi obecnie do konfliktów przy okazji przejmowania dawnych cerkwi greckokatolickich od prawosławnych. Problem staje się nie do rozwiązania, gdy obiekt sakralny jest tylko jeden, a jego rozwiązanie wymaga budowy nowych cerkwi. 
Przełomowym w ogóle na Wschodzie, w tym i na byłych terenach Galicji Wschodniej, okazał się rok 1991/1992, kiedy to wyłoniła się niezależność państwowa ukraińska. Niejako ruszyła sprawa wolności religijnej i oczekiwanie „na nowe" nie tylko w stosunku do Cerkwi prawosławnej ale także do Kościoła rzymskokatolickiego i grekokatolickiego na byłych Kresach Małopolski Wschodniej.

I właśnie z tą nadzieją na pozytywne zmiany ks. Marian Jaworski, Lwowianin, dnia 24 V 1984 roku został mianowany administratorem apostolskim archidiecezji z siedzibą w Lubaczowie ${ }^{126}$. Pozostawał trud dojazdów z Lubaczowa do Lwowa i z powrotem, gdyż brakowało we Lwowie siedziby biskupiej. Nie było Kurii Biskupiej i miejsca na zorganizowanie urzędów kościelnych. Dnia 16 I 1991 roku papież Jan Paweł II odnowił administrację kościelną na Ukrainie i mianował biskupów we Lwowie, Kamieńcu Podolskim i Żytomierzu. We Lwowie - abp Marian Jaworski został mianowany metropolitą lwowskim, a 18 maja tego roku odbył się ingres do bazyliki metropolitalnej pw. Wniebowzięcia NMP we Lwowie, dokąd przeniósł rezydencję swoją i Kurię Diecezjalną z Lubaczowa. Przeniesienie siedziby Kurii Diecezjalnej do Lwowa jeszcze bardziej zdynamizowało życie religijne i rejestrowanie kolejnych parafii katolickich na Ukrainie. Arcybiskup Jaworski zamieszkał tymczasowo u sióstr zakonnych we Lwowie, a następnie w zakupionym domu przy ulicy Ułasa Sawczenki 14 A. Po wizycie Ojca Świętego na Ukrainie w 2001 władze oddawały stopniowo metropolicie Jaworskiemu dawny pałac arcybiskupów lwowskich przy ul. Wynnyczenki (Czarneckiego), który w 2005 roku przejęty został w całości przez metropolitę. Obecnie prowadzone są prace remontowo-budowlane w pałacu arcybiskupów lwowskich. Wielka szkoda, by nie powiedzieć krzywda, że w momencie zwrotu pałacu arcybiskupów lwowskich prawowitemu właścicielowi, tamtejsza społeczność grekokatolicka w ciągu nocy „otwarła” i zarejestrowała parafię pw. Ofiarowania Matki Bożej w przyległym do pałacu dawnym kościele seminaryjnym, który wraz z pałacem stanowił W przeszłości całość. Na dzień dzisiejszy odprawiana jest tam jedna Msza św. w języku polskim dla rzymokatolików ${ }^{127}$.

W Żytomierzu (diec. kijowsko-żytomierska) biskupem został bp Jan Purwiński (od 16 I 1991). W Kamieńcu Podolskim pasterzem tamtejszego Kościoła był bp Jan Olszański (1919-2002). Po nim biskupem diecezjalnym został dotychczasowy bp pomocniczy kamieniecko-podolski, Leon Dubrawski (od 4 V 2002).

W 1993 roku Jan Paweł II utworzył administrację apostolską na Zakarpaciu (diec. mukaczewska), na czele z abp. Antonio Franko. Dnia 9 XII 1995 roku mianował biskupem pomocniczym administratury apostolskiej Zakarpacia Antała Majneka, konsekrując go w Rzymie 16 I 1996 roku. W 1997 roku Antał Majneka został administratorem apostolskim na Zakarpaciu, od 27 III 2002 r. biskup diecezjalny mukaczewski.

18 V 1996 roku papież odnowił diecezję łucką, mianując jej administratorem

${ }^{126}$ Wcześniej w 1974 roku bp Marian Rechowicz został mianowany administratorem archidiecezji z siedzibą w Lubaczowie, od czasu kiedy bp Eugeniusz Baziak, po 1946 roku, był zmuszony opuścić Lwów.

${ }^{127}$ Naoczni świadkowie do dziś z wielkim rozrzewnieniem wspominają tę chwilę, tak ważną i historyczną, a w rzeczywistości w skromnej oprawie. 
apostolskim metropolitę lwowskiego Mariana Jaworskiego. 25 III 1998 roku papież mianował ordynariuszem łuckim bpa Markijana Trofimiaka, biskupa pomocniczego ze Lwowa.

Jeszcze przed ogłoszeniem niepodległości Ukrainy wyjeżdżali z Polski kapłani, którzy bez wiedzy i zezwolenia jakichkolwiek władz kościelnych sporadycznie sprawowali liturgię dla tamtejszych wiernych. Wykorzystywali na celebrację wszelkiego rodzaju okazje i święta liturgiczne; modlitwę za zmarłych na cmentarzu łączyli z liturgią Mszy św. Z upływem czasu tamtejsi katolicy odzyskiwali zabrane im i zamknięte dla kultu świątynie, do których poszukiwano duszpasterzy. Kapłani przyjeżdżali z zagranicy, głównie z Polski. Z każdym rokiem ich napływ stawał się coraz większy. Podejmowali pracę w tworzonych i rejestrowanych wspólnotach parafialnych. W tej liczbie znaleźli się także salezjanie. Ich praca duszpasterska skupiła się głównie w archidiecezji lwowskiej i była sukcesywnie inspirowana przez metropolitę lwowskiego, apba Mariana Jaworskiego.

Parafia Piotra Apostoła w Odessie (obwód Odessa, diec. odesko-symferopolska). Nieprzerwanie w Odessie od kilkudziesięciu lat pracował ks. prał. Tadeusz Hoppe. Odeska prokatedra pw. Wniebowzięcia NMP zamknięta została przez komunistów w 1949 roku. Wcześniej prokatedrę zamknięto w 1936 roku, co było jednym z przejawów prześladowania Kościoła, rozpoczętego w 1935 roku. Została wówczas ograbiona z przedmiotów kultu i obrazów. Jej otwarcie nastąpiło w 1941 roku. Po ponownym zamknięciu w 1949 roku świątynia została przebudowana z przeznaczeniem na obiekt sportowy. Zarówno parafianie jak i ksiądz prałat nie zapomnieli o świątyni odeskiej. Ich wspólna modlitwa i zabiegi sprawiły, że dnia 9 VIII 1991 roku została zwrócona katolikom. Tamtejsza społeczność katolicka to przede wszystkim Polacy, stąd też oni podjęli ciężar odbudowy byłego pałacu sportu, na czele z przybyłym do Odessy w 1990 roku ks. Ignacym Ryndzionkiem, jako proboszczem, który na ten czas zamieszkał nad zakrystią. Ks. Ryndzionek zabiegał u osób prywatnych i instytucji w Polsce i za granicą o środki na prowadzone prace restauracyjne i budowlane. ${ }^{128}$.

W pracy duszpasterskiej pomagali mu współbracia: ks. Joachim Jasita i ks. Vitalij Krivitskiy (Krzywicki), tamtejszy rodak wyświęcony w 1997 roku, ks. Marian Kuc (wyśw. w 2001), pochodzący ze Lwowa.

We wrześniu 2003 roku salezjańscy duszpasterze w katedrze przekazali świątynię i duszpasterstwo miejscowemu biskupowi Bronisławowi Bernackiemu i klerowi diecezjalnemu. Salezjanie zamieszkali w otwartym domu zakonnym w Odessie - w Salezjańskim Centrum Młodzieżowym im. św. Dominika Savio przy ul. Malinowskiego $35 \mathrm{~A}$.

Obecnie (2005) w katedrze Wniebowzięcia NMP Mszę św. odprawiają również grekokatolicy, którzy nie mają swojej świątyni w Odessie. Biskup Bernacki docenia niedawną wspólną deklarację przyjętą przez Kościoły: katolicki w Polsce i grekokatolickie na Ukrainie o potrzebie zgody między konfesjami. Nie kryje jednak, że deklaracja deklaracją, a trzeba autentycznego pojednania.

${ }^{128}$ Ks. Ignacy Ryndzionek do ks. W. Żurka z 14 XI 2005 roku - Korostyszew (zb. aut.). 
Parafia pw. św. Mikołaja w Bóbrce (obwód Lwów, rejon Przemyślany, arch. lwowska, dek. Złoczów). To najmniejsze miasto Ukrainy, najbiedniejszego powiatu Bóbrka, województwa lwowskiego. Potok-rzeczka Bóbrka przecina zasiedloną część miasteczka, zbierając wodę z szerokich okolic Chodorowa, aby zasilić wody Dniestru. W północnej części miasta, na południowym stoku położony jest cmentarz, bogaty w nagrobki z przeszłości i mocno zaniedbany. W 1999 roku na 4000 mieszkańców Bóbrki ok. 300 deklarowało się rzymokatolikami.

Według tradycji fundatorem pierwszego kościoła miał być król Kazimierz Wielki. W 1548 roku abp lwowski Piotr Starzechowski odnowił fundację fary, w 1628 roku parafia została wcielona do kolegium misjonarzy ze Lwowa. Obecny kościół (ok. 1621) stoi na miejscu zniszczonego przez Tatarów. Świątynia miała charakter obronny o czym świadczą zachowane otwory strzelnicze. Wał obronny wokół świątyni istniał jeszcze w końcu XVIII w. Jej przebudowa w latach 19141922 zatarła ślady dawnych fortyfiakcji. Obecny kościół murowany, tynkowany, na planie krzyża, pozbawiony jest dekoracji architektonicznych ${ }^{129}$.

Po II wojnie udało się uniknąć zamknięcia kościoła. Dokonały tego władze komunistyczne w 1962 roku niszcząc całkowicie wnętrze świątyni i przeznaczając budynek do celów niekultowych ${ }^{130}$. Wówczas wierni gromadzili się na modlitwę w cmentarnej kaplicy Czajkowskich, a inicjatorem tych spotkań modlitewnoliturgicznych był miejscowy stolarz Michał Tarnawski (1904-1995). Te praktyki miejscowe władze tolerowały przez prawie 30 lat.

Odzyskany przezkatolików w grudniu 1989 rokukościółparafialnyśw.Mikołaja został poświęcony przez metropolitę lwowskiego, bpa Mariana Jaworskiego w IV niedzielę adwentu 1989 roku. Pierwszym proboszczem w Bóbrce został ks. Ludwik Kamilewski, wikariusz z katedry lwowskiej. W pracy parafialnej pomagali m. in. o. Stanisław Fudala - karmelita, ks. Andrzej Baczyński - salezjanin z Lwowa, ks. Piotr Smolka - salezjanin pracujący w niedalekich Przemyślanach oraz przyjeżdżający z Polski kapłani, głównie zakonnicy. Jednak na miejscu w Bóbrce nie było stałego proboszcza. Dopiero w jesieni 1995 roku probostwo przejął tam na kilka miesięcy ks. Piotr Malec, były misjonarz salezjański z Zambii. Po nim krótko (od sierpnia 1996) proboszczował ks. Marek Poniewierski, którego od listopada tego roku zastąpił go jego współbrat, ks. Stanisław Buchta. W październiku 2005 roku probostwo przejął ks. Edward Mackiewicz ${ }^{131}$. W pracy duszpasterskiej pomagał

${ }^{129}$ J. Tokarski, Ilustrowany przewodnik po zabytkach kultury na Ukrainie, t. 1, Warszawa 2000, s. 20.

${ }^{130}$ Przez kilkanaście lat - do 1962 roku duszpasterzował w Bóbrce ks. Janosz Rabar, birytualista, dopóki nie został zdemaskowany, że jest kapłanem greckokatolickim. Węgier z pochodzenia, znający język polski. Do pracy w Bóbrce nakłonił go proboszcz katedry lwowskiej, o. Rafał Kiernicki, gdy ks. Janosz wyszedł z więzienia na wolność. Po objęciu probostwa w Bóbrce miał ukrywać fakt, że jest księdzem grekokatolickim i ma rodzinę. Po ujawnieniu całej prawdy przez KGB został skazany na 10 lat pracy fizycznej w miejscowej cegielni, z obowiązkiem zamieszkania w Bóbrce. Po odbyciu kary powrócił do rodziny na Zakarpacie. Zmarł na początku lat 90 . ubiegłego stulecia. Relacja ks. Andrzeja Baczyńskiego z 200 II 2006 roku - Przemyślany (zb. aut.).

${ }^{131}$ Ks. Mackiewicz Edward, po kilkumiesięcznej pracy, jako administrator domu salezjanów litewskich w Kownie-Palemonas (od połowy marca 2004). Po fuzji salezjanów litewskich do pro- 
tam od 2004 roku ks. Edward Zajączkowski, jako wikariusz parafii, od 2006 roku ekonom inspektorialny w Moskwie.

$\mathrm{W}$ tym miasteczku duszpasterstwo jest najlepiej zorganizowane, z racji oczywistych, odnowiony kościół po częściowym spaleniu. Tutaj z placówek salezjańskich najliczniejsza jest wspólnota rzymskokatolicka. Prawdziwą chlubą są ministranci oraz schola. Na Mszy św. są ustawione sztandary wzdłuż nawy kościoła, a dzwony przywołują wiernych na modlitwę. Systematycznie prowadzona jest katechizacja dzieci i młodzieży.

Bardzo oryginalną inicjatywę w Bóbrce podjął w 2000 roku proboszcz, ks. Stanisław Buchta. W wybudowanej obszernej plebanii zorganizował dla siódemki miejscowych dziewcząt szkół powszechnych całodobową opiekę: mieszkanie, wyżywienie, wychowanie i kształcenie. $Z$ tej liczby piątka dziewcząt to rodzeństwo, dwie pozostałe pochodzą $\mathrm{z}$ innych rodzin, których rodzice zostali pozbawieni praw rodzicielskich. Ze strony władz oświatowych odpowiedzialna jest za nie wychowawczyni świecka. Plebania katolicka zastąpiła dziewczynkom dom rodzinny. Po sześciu latach, gdy najstarsza z grupy rodzeństwa uzyskała pełnoletność, miejscowe władze przydzieliły im mieszkanie, do którego będą mogły się wprowadzić latem 2006 roku. Pod opieką salezjanów pozostaną jeszcze dwie dziewczynki, które nadal oczekują z nadzieją, że może i one otrzymają własne mieszkanie ${ }^{132}$.

Od momentu rejestracji parafii w Bóbrce w pracy duszpasterskiej pomagają Siostry Franciszkanki Rodziny Maryi, które posiadają na miejscu dom zakonny. Prowadzą katechizację, zakrystię, troszczą się o bieliznę kościelną, przygotowują dekoracje w kościele i prowadzą parafialne grupy młodzieżowe.

Parafia św. Stanisława Biskupa i Męczennika w Dunajowie (obwód Lwów, arch. lwowska, dek. Złoczów). Wioska położona wśród wzniesień, które swoimi stokami dotykają ciągnącego się od Rohatyna pasma wzniesień, noszącego nazwę Gołogóry, a od południa wchodzą w ziemie Podolskie. Ubogie chałupinki Dunajowa ciągną się spiralą wzdłuż potoku Złota Lipa, który przepływa przez Brzeżany i dalej jako lewobrzeżny dopływ wpada do Dniestru. Na miejscu nie ma stałego proboszcza, nawet duszpasterza. Parafia obsługiwana jest przez proboszcza z Bóbrki.

Tamtejszy kościół św. Stanisława zbudowany został ok. 1485 roku. Zniszczony przez Tatarów i odbudowany w następnym stuleciu spełniał także funkcje obronne. Świadczą o tym zachowane na wieży i pod dachem prezbiterium otwory strzelnicze. Wnętrze świątyni zdobią malowidła L. Winterowskiego z pierwsze-

wincji mediolańskiej wyjechał na urlop zdrowotny do Polski i miał żegnać się z pracą w Okręgu Wschodnim. Tymczasem na rekolekcjach odprawianych w Przemyślanach we wrześniu 2005 roku inspektor Okręgu Wschodniego, ks. Henryk Boguszewski mianował ks. Mackiewicza na wikariusza w Bóbrce, gdzie przybył 14 października tego roku. Dnia 18 XI 2005 roku otrzymał od inspektora nominację na proboszcza, a dekretem metropolity lwowskiego z dnia 3 grudnia tego roku został mianowany administratorem parafii w Bóbrce. Relacja ks. Edwarda Mackiewicza z 20 II 2006 roku - Przemyślany (zb. aut.).

${ }^{132}$ Relacja ks. Stanisława Buchty z 3 VI 2004 roku - Bóbrka (zb. aut.). 
go dziesięciolecia XX w. Współczesny kościół jest murowany, zabytkowy, nieco zniszczony. Obecnie odnawiają go zakłady konserwacji we Lwowie ${ }^{133}$

Parafia Narodzenia NMP Korostyszewie (obwód Żytomierz, diec. kijowsko-żytomierska). Niedaleko Żytomierza, na Ukrainie, leży Korostyszew, 40-tysięczne miasto. Jednym z pierwszych duszpasterzy był tam ks. Jan Purwiński, dojeżdżający z Żytomierza, który już jako biskup diecezjalny przekazał w 1991 roku parafię korostyszewską salezjanom.

Księdzu Purwińskiemu pomagał (od czerwca do września 1991) salezjanin, ks. Antoni Murziński z Żytomierza, który dnia 19 IX 1991 roku został mianowany tam proboszczem. Parafia liczyła wówczas około 300 wiernych. Po przejęciu parafii przez salezjanów przełożonym erygowanego domu zakonnego w Korostyszewie został tamtejszy proboszcz, ks. Murziński.

Położył on ogromne zasługi w budowaniu wspólnoty Kościoła żywego oraz w odbudowie samej świątyni. Ta w okresie rządów stalinowskich została zamieniona na kino-teatr. Dzięki podjętym pracom restauracyjnym świątynia odzyskała pierwotny wygląd architektoniczny. W tym dziele wielce dopomógł mieszkaniec miasta, który znał z pamięci szczegóły architektoniczne kościoła przed jego zamknięciem. Przed kilkudziesięciu laty, zmuszony przez ówczesne władze, jako młody murarz przebudowywał zamknięty kościół na kino-teatr. A teraz po kilkudziesięciu latach, już jako sędziwy murarz przywracał dawny wygląd sakralny oddanej świątyni. Otrzymała ona nowy wystrój wewnętrzny, według projektu ks. Tadeusza Furdyny z Łodzi, salezjanina i projektanta wnętrz sakralnych. Wspomniany mistrz murarski prace restauracyjne wykonał społecznie ${ }^{134}$.

W październiku 1995 roku ks. Murziński został przeznaczony do domu nowicjackiego w Oktiabrsku. Na jego miejsce przybył do Korostyszewa ks. Jan Niemiec, wyrzucony przez władze Białorusi z parafii w Oszmianie. W kwietniu 1996 roku ks. Niemiec powrócił na Białoruś do parafii w Borunach. Kolejnym proboszczem i przełożonym w Korostyszewie został w tym roku ks. Cezary Czerwiński. W 2003 roku zastąpił go kolejny proboszcz ks. Vitalij Krzyvicki, a przełożonym pozostał nadal ks. Cezary ${ }^{135}$.

W tamtejszej parafii pracował od 1998 roku ks. Józef Żołnowski, który był równocześnie proboszczem w Brusiłowie. Obecnie, będąc chorym pozostaje tam jako rezydent. Od października 2002 roku do marca 2004 roku pracował jako wikariusz parafialny i administrator domu w Korostyszewie ks. Edward Mackiewicz. W marcu 2004 roku ks. Edward wyjechał na Litwę do Kowna. Od grudnia 2005 roku pracuje w tamtejszej parafii jako wikariusz ks. Józef Bogusz

Świątynia korostyszewska została poświęcona przez biskupa w 1997 roku Liczba wiernych dochodzi obecnie do 2 tysięcy osób. Salezjanie (trzech) dojeżdżają ponadto do 14 punktów duszpasterskich, w których gromadzą się wierni na liturgię, w tym do dwu miast: Brusiłowa i Józefówki ${ }^{136}$.

\footnotetext{
133 Tokarski, Ilustrowany przewodnik po zabytkach kultury na Ukrainie, s. 36.

${ }^{134}$ Weder, Znaki nadziei, s. 53-54.

${ }^{135}$ Relacja ks. Cezarego Czerwińskiego z 20 II 2006 roku - Przemyślany (zb. aut.).

${ }^{136}$ Ks. Ignacy Ryndzionek do ks. W. Żurka z 14 XI 2005 roku - Korostyszew (zb. aut.).
} 
Parafia Świętych Apostołów Piotra i Pawła w Przemyślanach (obwód Lwów, rejon Przemyślany, arch. lwowska). Miasteczko z ok. 4,5 tys. ludności leżące na trasie Lwów - Stanisławów, terenie topograficznie zróżnicowanym. Przez Przemyślany przepływa potok-rzeczka Gniła Lipa, dalej przez Rohatyn, jako lewobrzeżny dopływ wpada do Dniestru. Przemyślany były granicznym powiatem między województwami tarnopolskim a lwowskim, sąsiadującym z powiatem Bóbrka.

Na miejscu pierwotnej kaplicy kościół murowany ufundowała księżna Elżbieta Potocka w 1665 roku, powierzając go dominikanom. Konsekrowany w 1730 roku otrzymał tytuł Świętych Apostołów Piotra i Pawła. Świątynia posiada wysoką wieżę i zdobną fasadę, obok stoi dzwonnica. W 1939 roku została zamknięta przez sowietów. Wkrótce otwarta, w 1946 roku została ponownie zamknięta przez władzę radziecką na kilkadziesiąt lat. Ostatnim proboszczem w Przemyślanach do momentu zamknięcia kościoła był ks. Piotr Stanaszek.

W grudniu 1991 roku została zarejestrowana w Przemyślanach parafia rzymskokatolicka, staraniem ks. Ludwika Kamilewskiego, wikariusza katedry lwowskiej, i ks. Andrzeja Baczyńskiego - salezjanina. Przez 5 lat wierni gromadzili się na liturgię pod gołym niebem przy powiększonej kaplicy cmentarnej, zaadaptowanej do funkcji liturgicznych. Powiększono ją i zadaszono a wnętrze wyklejono tekturą i papierami. Tamtejsi wierni byli ambitni i nieustępliwi w staraniach o odzyskanie kościoła parafialnego. Oddana świątynia, dnia 1 IV 1997 roku została poświęcona przez metropolitę lwowskiego, abp. Mariana Jaworskiego. Parafię obsługują salezjanie, najpierw czynił to ks. Andrzej Baczyński z pomocą ks. Piotra Smolki. Rodzina Kłosowskich podejmowała u siebie kapłanów na nocleg i przygotowywała posiłki.

Obecnie funkcję proboszcza pełni tam od 1994 roku ks. Piotr Smolka, który pracuje na Ukrainie od 4 VIII 1993 roku. W parafii od 1997 roku pomaga mu wikariusz ks. Franciszek Rosłan i ks. Jan Niemiec. Ten ostatni w roku 2006 powrócił do Polski.

Salezjanie z Przemyślan dojeżdżają z posługą do Świrskich Chebowic, gdzie wybudowaną $\mathrm{w}$ ostatnich latach kaplicę św. Antoniego poświęcił dnia 4 IX 2004 roku kard. Marian Jaworski. Ponadto obsługują także kościół parafialny pw. Świętych Apostołów Piotra i Pawła w Mitulinie, w Pohorylcach i kaplicę w Pleceniach.

Staraniem duszpasterzy parafialnych ukazuje się w Przemyślanach biuletyn parafialny i miesięcznik - „Źródło wiary”. W lutym 2006 roku ukazał się jego 20(36) numer. Redaktorem naczelnym jest proboszcz - ks. Piotr Smolka. Pomagają mu współpracownicy: Elżbieta Bajkowa, Maria Krywa, Wira Pryszlakiwska, Orysia Zadorożna, Artur Górnik, Jerzy Lach. Biuletyn na swych stronach zawiera bloki informacyjne z życia parafii i działalności jej agend, kalendarz liturgiczny na nadchodzący miesiąc, kącik katechizmowy, aktualności z życia Oratorium parafialnego oraz imprez religijnych i rozrywakowych dla dzieci i młodzieży. Ostatnią część stanowią strony „kropelka radości” czyli anegdoty, zagadki, krzyżówki.

Salezjanie przez pewien czas pracowali w parafii w Rychalsku na Ukrainie, gdzie w latach 1992-1997 pełnił obowiązki proboszcza ks. Józef Żownowski. 
Także w Berdyczowie na Ukrainie w 1992/1993 roku ks. Cezary Czerwiński pełnił obowiązki wikariusza parafii.

Rodacy oraz ich potomkowie pochodzący z Kresów po rozpadzie Związku Sowieckiego odzyskują, odbudowują i budują świątynie katolickie aby służyły do celów kultowych. Okrutne czasy ostatniej wojny oraz rządów komunistycznych zniszczyły bezpowrotnie wiele, nie pozostawiając śladu po miejscach i budowlach sakralnych.

Nierzadko spalona świątynia, zniszczony cmentarz ${ }^{137}$ - wspomnienie i historia - to wszystko co zostało tamtejszym katolikom po przodkach. W odbudowywaniu lub budowie świątyń katolickich nie wystarczają lokalne środki finansowe. Pomagają rodacy z zagranicy i z Polski. Nieocenioną pomoc świadczy Wspólnota Polska z Warszawy oraz Senat Rzeczypospolitej Polskiej. Dzięki temu wokół katolickiego księdza i kościoła gromadzą się wierni spragnieni nauki o Bogu i języka polskiego. Dla wielu z nich kościół jest drugim miejscem po domu rodzinnym. Głównie dzieci i młodzież przychodzą po szkole i przebywają niejednokrotnie do wieczora na plebanii lub w salce katechetycznej. Tu uczą się języka polskiego, informatyki, oglądają polskie programy telewizyjne. To poszerza ich umiejętności, zdobywają też pewne kwalifikacje zawodowe, co w dzisiejszych czasach jest nieodzownym warunkiem zdobycia pracy ${ }^{138}$.

Ks. Tadeusz Pater ${ }^{139}$ od kiedy rozpoczął pracę duszpasterską w parafii św. Józefa w Przemyślu na Zasaniu, myślał o swoich stronach rodzinnych i miejscowości Rumno koło Lwowa. W styczniu 1994 roku odbył wizytę w konsulacie RP we Lwowie. Wówczas poruszył temat upamiętnienia 50. rocznicy tragicznych wydarzeń w Rumnie z końca II wojny. W maju tego roku ks. Pater otrzymał zezwolenie władz ukraińskich na sporządzenie planów tamtejszego polskiego cmentarza. Po wizycie w Rumnie 21 II 1994 roku wraz z ks. Andrzejem Baczyńskim zapo-

${ }^{137} \mathrm{~W}$ niejednej miejscowości cmentarze zostały zniszczone (ogrodzenie, bramy wejściowe) i koleją losu „przeznaczone” do celów gospodarczych. Dla przykładu m. in. w Hołobach, Kamieniu Koszyrskim, Lewaczach, Kisielinie, Mielnicy, Torczynie na terenie diecezji łuckiej. Dziś na byłych cmentarzach pasie się bydło i bydlęce odchody leżą między zniszczonymi nagrobkami, płytami i połamanymi krzyżami. I. Wójcik, Torczyn na Wołyniu na nowo odżyt (I) i (II), „Niedziela ZamojskoLubaczowska" z dnia 2 i 9 IX 2001 roku, s. 23.

${ }^{138}$ Wójcik, Torczyn na Wotyniu na nowo odżyt (I) $i$ (II), „Niedziela Zamojsko-Lubaczowska” z 2 i 9 IX 2001 roku, s. 23.

${ }^{139}$ Pater Tadeusz, ur. 20 V 1933 roku w Rumnie.W 1945 roku zmuszony z rodzicami i rodziną do ekspatriacji na Ziemie Zachodnie. Ukończył nowicjat salezjański w Kopcu, gdzie złożył śluby 5 VIII 1951 roku w Kopcu. Święcenia kapłańskie otrzymał 24 V 1960 roku w Krakowie. Pracował długie lata w szkolnictwie i duszpasterstwie parafialnym. Obecnie, gdy jest na emeryturze, kontynuuje swą pracę dydaktyczną w inny sposób. Jako utalentowany pisarz dał w kolejnej książce: Listach o Kresach poludniowo-wschodnich wykład z przeszłości oraz o dniu dzisiejszym rodzinnej ziemi. Jako „wiarygodny świadek”, urodzony w II Rzeczypospolitej w okolicy Lwowa, doświadczony kataklizmem wojny i ekspatriacji, żyjący w trudnych latach w PRL-u, gdy prawda o Kresach oraz ich martyrologii nie mogła być społeczeństwu podana, dziś pragnie nowemu pokoleniu przybliżyć przeszłość Ziemi Utraconej. Służy w ten sposób piórem integrując rozproszoną społeczność ekspatriantów. Mobilizuje ich ofiarność na rzecz mniejszości polskiej egzystującej dziś na Ukrainie w trudnych warunkach. T. Pater, Listy o Kresach południowo-wschodnich, Kraków 2006. 
znał się ze stanem faktycznym cmentarza katolickiego. Podjęli wówczas myśl nie tylko uporządkowania cmentarza ale także upamiętnienia tragicznych wydarzeń sprzed 50 lat i przygotowania godnego miejsca pochówku pomordowanych Rodaków. Na podstawie przygotowanej listy pomordowanych, ks. Pater skierował odpowiednie pismo do władz kościelnych i państwowych na Ukrainie ${ }^{140}$. Patronat nad tym przedsięwzięciem objął abp Ignacy Tokarczuk, senior w Przemyślu.

Owocem zabiegów ks. Tadeusza było, że po 50 latach stanął na polskim cmentarzu w Rumnie, nad rozległym kopczykiem, znakiem wspólnotowej mogiły pomordowanych Rodaków i męczenników, krzyż-pomnik. Obecnie cmentarz jest ogrodzony, bydło nie ma tam dostępu. Wykonano bramę wejściową. Wiele figur nagrobnych stanęło na swoim miejscu, a wiele też nowych przybyło z inicjatywy miejscowej ludności ukraińskiej, poczuwającej się do wspólnoty modlitewnej. Na pomniku umieszczono napis: 1994 - 50. rocznica tragedii Polaków w Rumnie; 1995 - 50. rocznica wysiedlenia na Ziemie Zachodnie ${ }^{141}$.

Dnia 16 I 2006 roku przypadła 15. rocznica reaktywowania struktur Kościoła katolickiego na Ukrainie. Katolicy, i nie tylko, wspominają tę historyczną chwilę, kiedy Wielki Papież Jan Paweł II mianował dla Lwowa metropolitę w osobie abpa Mariana Jaworskiego. Dnia 28 I 2001 roku Jan Paweł II ogłosił abpa Jaworskiego kardynałem Kościoła katolickiego (od 21 II 1998 roku kardynał „in pectore”). Ojciec Święty ogłosił także ks. Lubomyra Huzara kardynałem obrządku bizantyjsko-ukraińskiego z siedzibą we Lwowie. Od 2006 roku w Kijowie ${ }^{142}$.

\section{d) Delegatura Inspektorialna Ukrainy pw. Maryi Wspomożenia Wiernych obrządku bizantyjsko-ukraińskiego we Lwowie}

Współbracia obrządku bizantyjsko-ukraińskiego i ich domy należały do Okręgu Wschodniego i podlegały jurysdykcji inspektora urzędującego w Moskwie. Na Kapitule Okręgu Wschodniego w 2004 roku salezjanie obrządku bizantyjsko-ukraińskiego przedłożyli projekt utworzenia Delegatury Salezjańskiej na Ukrainie $^{143}$. Projekt uzyskał pozytywną ocenę podczas głosowania uczestników

${ }^{140}$ Wystosował wówczas pismo do abpa Mariana Jaworskiego - metropolity lwowskiego ob. łac.; Mirosława Lubacziwskiego - arcybiskupa większego z katedry św. Jura we Lwowie; Henryka Litwina - konsula RP we Lwowie, inż. Stanisława Czerkasa - prezesa Towarzystwa Kultury Ziemi Lwowskiej we Lwowie oraz do hołowy w Rumnie wraz z mieszkańcami.

${ }^{141}$ T. Pater, Rumno. Pomnik Pamięci 1939-1944, Przemyśl 1998, tenże, Oczyma i sercem. Wieś Rumno w latach 1939-1945, T. 1 Tak onegdaj bywało w Rumnie, T. 2 Trudne losy okupacyjne rodzin polskich w Rumnie, Przemyśl 2000.

${ }^{142}$ Kronika Archidiecezji Lwowskiej, „Radość Wiary”. Religijno- Archidiecezji Lwowskiej obrządku łacińskiego, $\mathrm{Nr} 1$ (56) 2006, s. 17; Rocznica reaktywowania hierarchii rzymskokatolickiej na Ukrainie, tamże, s. 18.

${ }^{143}$ Inicjatywa utworzenia bizantyjsko-ukraińskiej gałęzi w Zgromadzeniu Salezjańskim sięga 1930 roku, z inspiracji ówczesnego nuncjusza apostolskiego w Polsce - abpa Franciszka Marmaggi. Przełożony Generalny Zgromadzenia, ks. Filip Rinaldi pozytywnie ustosunkował się do propozycji nuncjusza. Już w 1932 roku udała się pierwsza grupa ukraińskich młodzieńców na salezjańską formację do Włoch. W następnych latach $(1937,1938,1939)$ wyjechały kolejne grupy. Ci kandydaci, późniejsi salezjanie, nie posiadali własnej państwowości, a w Ukraińskiej SRR religia katolicka 
Kapituły. Na tej podstawie przełożony Okręgu Europa Wschodnia, ks. Henryk Boguszewski, przesłał stosowną prośbę do zatwierdzenia Radzie Wyższej w Rzymie. Ta wziąwszy pod uwagę przedstawione motywacje, związane przede wszystkim z koniecznością zachowania i rozwoju salezjańskiego charyzmatu w obrębie Kościoła Wschodniego, dokonując w nim jego inkulturacji tak w obrzędowości bizantyjsko-ukraińskiej jak i przez odpowiednie struktury, projekt przegłosowała pozytywnie. Na tej podstawie Generał Zgromadzenia postanowił ustanowić Delegaturę Salezjańską dla Ukrainy obrządku bizantyjsko-ukraińskiego z siedzibą w domu pw. Maryi Wspomożycielki Wiernych we Lwowie, przy ul. Łyczakowskiej 175. W jej skład weszły placówki salezjańskie na Ukrainie obrządku bizantyjsko-ukraińskiego wraz ich dziełami i współbraćmi, po wyłączeniu ich z Okręgu Wschodniego. Delegatura rozpoczęła oficjalnie działać 15 VIII 2005 roku. Na przełożonego Delegatury został wyznaczony ks. Onorino Pistellato, Włoch z pochodzenia. Podstawowym celem Delegatury jest animacja życia i powołania na Ukrainie, poprzez inkulturację charyzmatu ks. Bosko w ukraińskim Kościele. Podstawowym obrządkiem sprawowania kultu w Delegaturze jest obrządek bizantyjsko-ukraiński. Pomimo że Delegatura przynależy do Zgromadzenia Salezjańskiego na prawie papieskim, o dopuszczenie do nowicjatu nadal należy zwracać się do Stolicy Apostolskiej o pozwolenie wymagane przez kan. 517 par. 2 PKKW, wraz z pozwoleniem na birytualizm dla uczestnictwa w celebracjach obrządku łacińskiego ${ }^{144}$.

Parafia św. Pokrowy we Lwowie (Marii Wspomożenia Wiernych, przy ul. Łyczakowskiej 175$)^{145}$. Współbracia obrządku bizantyjsko-ukraińskiego przejęli w 1991 placówkę parafialną w dzielnicy Górny Łyczaków, gdzie salezjanie prowadzili duszpasterstwo w latach 1934-1945. Po zajęciu świątyni w 1945 roku przez komunistów i zmianie granic państwa polskiego wyjechali ze Lwowa ostatni współbracia-Polacy w ramach ekspatriacji. Dziś przy parafii prowadzą Oratorium oraz szeroko zakrojoną pracę formacyjną z młodzieżą. Tamtejsza wspólnota zakonna liczy ok. 10 wpółbraci. Pierwszym dyrektorem i proboszczem parafii został ks. Vasyl Sapelak. Ks. Sapelak jest proboszczem do dzisiaj. Natomiast przełożonym wspólnoty zakonnej został w 2005 roku ks. Eugenio Nebesniak.

doznawała represji, stąd oni jako salezjanie pracowali wśród wiernych narodowości ukraińskiej na różnych kontynentach; głównie w obu Amerykach. Dopiero w 1991 roku powrócili do proklamowanego państwa Ukrainy, gdzie pracują obecnie.

${ }^{144}$ Dekret Przełożonego Generalnego o ustanowieniu Delegatury obrzadku bizantyjsko-ukraińskiego w Ukrainie, w: Dokumenty Rady Generalnej, Kraków 2005 nr 389 Rok LXXXVI kwiecieńczerwiec 2005, s. 81-82.

145 Świątynia Matki Boskiej Ostrobramskiej, wybudowana na wzgórzu w pobliżu Parku Łyczakowskiego staraniem lwowskiego abpa Bolesława Twardowskiego w latach 1931-1934, wg projektu prof. Tadeusza Obmińskiego. Była wotum wdzięczności Polaków za powrót Lwowa do Macierzy. Po konsekracji kościoła w 1934 roku z woli arcybiskupa duszpasterstwo w kościele przejęli salezjanie z Prowincji św. Jacka w Krakowie. Tokarski, Ilustrowany przewodnik po zabytkach kultury na Ukrainie, s. 95. 
Przy parafii salezjańskiej św. Pokrowy na lwowskim Łyczakowie funkcjonuje Oratorium młodzieżowe im. św. Dominika Savio.

Dowspólnotyzakonnej obrządkuukraińsko-bizantyjskiegozul.Łyczakowskiej we Lwowie należy placówka w Obroszynie (Obroshyno), gdzie mieści się aspirantat dla kandydatów do Zgromadzenia. Pracuje tam 3 salezjanów.

Młodzieżowe Ekumeniczne Centrum Nauczania im św. Jana Bosko we Lwowie. W ramach powstałego Centrum Ekumenicznego przy ul. Krzywczycka 17 A, salezjanie prowadzą Ośrodek Kształcenia Zawodowego (Centrum Kształcenia Zawodowego), oficjalnie uznany przez władze państwowe w 2003 roku. Jego dyrektorem został ks. Stefan Urban. W 2005 roku zastąpił go ks. Andrij Seneiko a ks. Urban przeszedł na p. o. dyrektora w Obroshynie.

Jest to współczesny trzypiętrowy budynek przeznaczony do edukacji, którego gospodarzami są salezjanie, pracujący na wszystkich kontynentach świata i mający doświadczenie w kształceniu zawodowym młodzieży. I tu we Lwowie młodzież ma możliwość kształcenia w Centrum. Kształcenie Zawodowe funkcjonuje od 2004 roku, ale dopiero w 2006 roku był właściwy pierwszy nabór uczniów. W tym bowiem roku kierownictwu Centrum uzyskało licencję państwową na kształcenie w trzech specjalnościach: sekretarz kierownika, operator komputerowy, stolarz i producent wyrobów z drewna (w tym stolarstwa artystycznego i rzeźbiarstwa) ${ }^{146}$.

Budynek Centrum posiada niezbędne dla uczniów pomieszczenia $\mathrm{z}$ ich odpowiednim wyposażeniem. Na podkreślenie zasługują pracownie zawodowe, wyposażone w najnowocześniejszy sprzęt i maszyny ${ }^{147}$, co było darem salezjanów niemieckich i tamtejszych władz.

Obok Centrum jest budowana pracownia stolarska, która w 2007 roku ma być oddana do nauczania.

Przyjęcie do szkoły odbywa się na podstawie rozmowy kwalifikacyjnej (szewce i stolarze) i egzaminu (sekretarz kierownika i operator komputerowy). Nauka w szkole jest bezpłatna. Każdy dzień nauki w szkole rozpoczyna się apelem i modlitwą prowadzoną przez dyrektora, ks. Andrija Seneiko. Absolwenci szkoły uzyskują dyplom państwowy.

W tej pracy salezjanom ukraińskim pomagają siostry salezjanki ${ }^{148}$.

Do wspólnoty salezjańskiego domu przy ul. Łyczakowskiej 175 należy placówka w Obroshynie gdzie mieści się aspirantat i prenowicjat współbraci obrządku bizantyjsko ukraińskiego. Od 1996 roku przełożony (p. o.) został ks. Vasyl Korol, od 2004 ks. Andrii Platosh, a w roku następnym ks. Stefan Urban.

„Świetlany Dom”w Odessie. Na przełomie lat 1988/89 w charytatywnej

${ }^{146}$ Oprócz wymienionych specjalności w Centrum kształcą się także na szewców i krawców . Nauka we wszystkich specjalnościach trwa 2 lata (wyjątek - na operatora komputerowego nauka trwa rok)

${ }^{147}$ Pracownia krawiecka posiada japońskie maszyny i szwedzki stół do prasowania parą.

${ }^{148}$ Działalność Rady Wyższej Radca Regionu Europa Pótnocna, w: Dokumenty Rady Generalnej, Kraków 2003, nr 382, Rok LXXXIV lipiec wrzesień 2003, s. 79 
Fundacji Pomocy Społecznej im. Doktora Gaaza w Odessie zaangażował się Aleksander Czumakow z grupą wolontariuszy. Uruchomiony został telefon zaufania dla młodych, którzy poszukiwali jakiejkolwiek pomocy w rozwiązywaniu swoich problemów życiowych. Równocześnie z „telefonem zrozumienia”, jak go w Odessie nazywano, tworzono formację Miłosierdzie Młodości (MIV), które skupiało ochotników pragnących pomóc bezdomnym dzieciom ulicy. Te dwie grupy wolontariuszy, wspólnie z pozyskanymi fachowymi pedagogami stworzyli w lecie 1989 roku stowarzyszenie „Skrzyżowanie”, które zgłaszającym się sierotom z ulicy zapewniało krótkoterminowe schronienie w suterenowych pomieszczeniach D. P. Rżepiszewskiego przy ul. Bazarnej w Odessie. Ta forma i miejsce pomocy otrzymała nazwę „Przytułek”. Była to działalność niepaństwowa oparta na ofiarności ludzi i instytucji. Ta działalność na rzecz dzieci maltretowanych, sprawcach i ofiar ulicznych rozbojów, młodych kryminalistów i narkomanów niepokoiła resortowych urzędników państwowych. To spowodowało, że na początku 1990 roku władze dzielnicy Żołtrzewa w Odessie zabroniły kilkakrotnie pracy z dziećmi w pomieszczeniach suterenowych przy ul. Bazarnej.

Faktycznie czteropokojowe pomieszczenie bez wentylacji, sanitariatów, nierzadko zalewane odpływami kanalizacyjnymi, w najmniejszym stopniu nie spełniało obowiązujących standardów mieszkaniowych. Rozpoczęła się „wojna” o przetrwanie „Przytułka”, trwająca do stycznia 1995 roku. Wówczas schronisko dziecięce „Przytułek”, którego szefem był D. P. Rżepiszewski, zostało zamknięte. Było to logiczne i do przewidzenia.

Jednak jak wytłumaczyć zmarzniętym, zawszonym, owiniętym w łachmany dzieciom koczującym w opuszczonych wagonach, na strychach, że ze względu na ich bezpieczeństwo i zdrowie przepisy nie zezwalają na działalność „Przytułka” w piwnicy, podczas gdy statystyki dzieci niczyich i pozostawionych własnemu losowi lawinowo rosły. Katastrofalna sytuacja tych dzieci wymagała natychmiastowego działania i takie zostało zainicjowane.

Pod koniec października 1995 roku przybył do Odessy, po odbyciu studiów seminaryjnych w Wyższym Seminarium Duchownym Towarzystwa Salezjańskiego w Krakowie, wspomniany na początku Aleksander Czumakow, jako diakon. Wówczas Społeczno Pedagogiczne Stowarzyszenie (SPO) „Siedem krasnoludków" pana Rżepiszewskiego rozpoczęło program, autorstwa diakona Czumakowa - ekologia dzieciństwa. Aleksander, zwany przez dzieci „ojcem”, przejął klucze od zamkniętego w styczniu tego roku „Przytułka” przy ul. Bazarnej.

Przejmując pomieszczenie, diak. Czumakow oparł pracę wychowawczą na rzecz dzieci ulicy na salezjańskim systemie wychowawczym, zwanym prewencyjnym, a wypracowanym przez zakonodawcę św. Jana Bosko (1815-1888). Ten system wychowawczy zakłada nieustanną obecność wychowawcy wśród podopiecznych, a swoje oddziaływanie na młodzież opiera na rozumie, religii i miłości.

Do wieczerzy wigilijnej 1995 roku „ojciec” Czumakow zasiadł w pomieszczeniach „Przytułka” z grupą oddanych tej pracy wolontariuszy. W trakcie śpiewania kolęd drzwi piwnicy uchyliły się i na próg ostrożnie wstąpiło pięcioro zmarzniętych i wygłodniałych maleństw odzianych w łachmany. Ich przybycie 
diak. Aleksander odczytał jako „znak z góry” a zamknięty „Przytułek” został reanimowany, wbrew wszelkim zakazom urzędowym. Kolejne miesiące roku 1996 były prawdziwą próbą sił o jego przetrwanie.

Jedyny na Ukrainie, niepaństwowy sierociniec o nazwie „Przytułek” działał dzięki wsparciu biednego społeczeństwa miasta, ludzi biznesu i działających firm. Tymczasem uaktywniła się działalność ukraińskiego Sanepidu, miejskich władz oświatowych, kulturalnych i zdrowia oraz najazdy urzędników likwidacyjnych. W końcu Rada miasta Odessy ogłosiła zawieszenie broni. Dla rozwiązania problemów finansowych nielegalnego schroniska o nazwie „Przytułek” została powołana dobroczynna Fundacja „Świetlany Dom”, z założycielem „ojcem” Aleksandrem Czumakowem ${ }^{149}$.

Dotychczasowy „Przytułek” otrzymał oficjalną nazwę ,Świetlany Dom”, który rozpoczął od $24 \mathrm{~V} 1996$ roku w miarę normalne funkcjonowanie. Jego urzędowa rejestracja nastąpiła $30 \mathrm{~V} 1996$ roku. Tymczasem w pomieszczeniach przy ul. Bazarnej rozpoczęto konieczne prace remontowo-modernizacyjne, w oparciu o ochotniczą pracę wolontariuszy. Już we wrześniu tego roku mieszkańcy „Świetlanego Domu” rozpoczęli naukę według własnego programu o nazwie „likwidacja analfabetów”. Dnia 24 XII 1996 roku władze miasta przekazały do dyspozycji schroniska sąsiedni budynek przedszkola, od pewnego czasu niezagospodarowany.

„Świetlany Dom” poczęli nawiedzać przedstawiciele władz, hierarchowie Kościoła, jednostki wpływowe i przedstawiciele organizacji krajowych i zagranicznych. Dziennikarze prasowi i reporterzy telewizyjni pisali i przygotowywali odpowiednie programy telewizyjne. Wszyscy okazywali i okazują ogromne zainteresowanie, gdyż temat jest na czasie i bardzo reklamowy. Oby tylko za ich apelami i deklaracjami szła konkretna pomoc dla młodych mieszkańców...

Od początku lutego 2006 roku Radca Generalny naszego Regionu Europy Północnej, ks. Albert Van Hecke z Rzymu, przeprowadzał wizytację nadzwyczajną polskiej Inspektorii św. Jacka. W trakcie wizytacji, na zebraniu współbraci w Lublinie przy ul. Kalinowszczyzna 3 z księdzem wizytatorem, lubelscy salezjanie zadali wizytatorowi pytanie na temat pracy salezjańskiego diakona Aleksandra Czumakowa w Odessie. Ks. Albert Van Hecke wypowiedział swoje spostrzeżenia poczynione w czasie wizytacji domów należących do Okręgu Wschodniego, $\mathrm{w}$ tym i w Odessie. Jest to forma pracy - relacjonował ks. Albert $-\mathrm{z}$ bezdomnymi, która odbiega od naszych wyobrażeń i standardów. Nierzadko są to dzieci, które w dotychczasowym życiu nigdy nie mieszkały w mieszkaniu czy domu, nie tylko rodzinnym, ale w ogóle. Żyły w dostępnych dla nich miejscach i spelunach poza domem. Praca nie jest łatwa zważywszy przeszłość wychowanków, ich poziom intelektualny, duchowy i kondycję zdrowotną. Pomimo tych wszystkich

${ }^{149}$ Współzałożycielami fundacji byli: prezes Fundacji „Zachyst”- W. I. Kucenko; obwodowy rabin - Iszaji Gisser; prezes miejskiej Fundacji Pomocy Społecznej - A. Kruppnik; generalny dyrektor Ukraińskiego Centrum Kultury „Ukraina” - A. P. Kryglikowa; dyrektor Instytutu Badawczego Kuratorium i Rehabilitacji - prof. D. P. Babow; dyrektor organizacji i budowy Liceum im. Diagielowa - T. M. Pussowa. W. Żurek, Oddziaływanie duszpasterskie salezjanów w Kościele katolickim na Ukrainie, „Archiwa Biblioteki i Muzea Kościelne”, 85 (2005) s. 433. 
„niedoskonałości” i „trudności” w naszym rozumieniu, jakie można zauważyć w funkcjonowaniu „Świetlanego Domu”, ksiądz radca deklarował, że na możliwe sposoby będzie pomagał diak. Aleksandrowi, mimo że na dzień dzisiejszy jego związek ze Zgromadzeniem czy odeską wspólnotą zakonną jest dość luźny. Pomaga biednym dzieciom i to jest najważniejsze ${ }^{150}$.

W czasie seminarium zorganizowanego przez Ukraiński Uniwersytet Katolicki św. Klemensa w Rzymie w sierpniu 1998 roku, „ojciec” Czumakow spotkał się na audiencji z papieżem Janem Pawłem II. Wówczas prezes „Świetlanego Domu” dowiedział się, że papież wiedział o funkcjonowaniu w Odessie schroniska dla bezdomnych dzieci. Na pożegnanie Ojciec Święty pobłogosławił jego mieszkańcom i dwukrotnie powtórzył: „,wytrzymać wszystko, mocno stać”. Jest to program działania na przyszłość, a słowa papieża powstrzymują od ostatecznej niekiedy rozpaczy.

\section{MOLDAWSKA SOCJALISTYCZNA REPUBLIKA RADZIECKA - REPUBLIKA MOLDAWII}

Losy obszaru położonego między rzekami Prutem i Dniestrem, stanowiącego obecnie Republikę Mołdawii, były burzliwe. Na przestrzeni wielu stuleci Mołdawia leżała na pograniczu wpływów Rosji i Turcji oraz była obiektem zmagań obu ekspansywnych państw. Ostatecznie w 1812 roku Rosja przyłączyła to terytorium do imperium rosyjskiego. Do I wojny światowej większość dzisiejszej Mołdawii wchodziła w skład guberni besarabskiej. Niewielka, wschodnia część, po wschodniej stronie Dniestru, należała do guberni podolskiej i chersońskiej.

Klęska militarna Rosji i rewolucja bolszewicka dokonały zmian granicznych. Obszar między Prutem i Dniestrem został włączony do Republiki Rumuńskiej. Międzywojenna rumuńska Besarabia, oprócz miasta Kiszyniowa, podzielona została na dziewięć okręgów administracyjnych: Bielce, Kaguł, Białogród, Chocim, Izmaił, Łopuszna, Orgiejów, Soroki, Bendery. Z pewnym przybliżeniem można stwierdzić, że trzy z nich (Białogród, Izmaił i Chocim) należą obecnie do Ukrainy, a pozostałe leżą w granicach dzisiejszej Mołdawii.

Obecnie nie cała gubernia besarabska leży w granicach Mołdawii.

Południowa część byłej guberni besarabskiej położona nad Morzem Czarnym, zwana dawniej rejonem akermańskim a później białogrodzkim, należy dziś do Ukrainy. Część północna położona na południe od Dniestru w rejonie chocimskim też nie należy obecnie do Mołdawii ${ }^{151}$.

\section{a) Mołdawska Socjalistyczna Republika Radziecka}

Po II wojnie światowej tereny Mołdawii stały się republiką radziecką. Mieszkało tam ok. 25 tys. katolików obrządku łacińskiego, głównie narodowości niemie-

${ }^{150}$ Żurek, Oddziaływanie duszpasterskie salezjanów w Kościele katolickim na Ukrainie, s. 437.

${ }^{151}$ P. Eberhardt, Sytuacja narodowościowa w Republice Mołdawii, „Przeglad Wschodni”, t. 7, z 1 (250), s. 215-217. 
ckiej i polskiej. Znaczna większość z nich skupiła się w stolicy - Kiszyniowie ${ }^{152}$. W tamtych latach pracował w Mołdawskiej SRR jedynie ks. Mikołaj Szczurek. Po jego śmierci w 1948 roku tamtejsze władze komunistyczne wyraziły w 1949 roku zgodę na pracę w Kiszyniowie ks. Bronisława Chodanionka, salezjanina.

Objął duży kościół pw. Opatrzności Bożej w centrum miasta, przy ul. Stalingradzkiej 85 (obecnie ul. Mitropolit Dosoftei 85). Z miejsca zamieszkania przy ul. Andrzejewskiej 27 do kościoła dojeżdżał ks. Bronisław motocyklem. Obsługiwał także okoliczne punkty duszpasterskie, jeżdżąc motocyklem, samochodem lub pociągiem. Służył katolikom i prawosławnym: Mołdawianom, Niemcom, Polakom. Do Kiszyniowa w późniejszym czasie przyjechała do niego matka Józefa oraz bratowa z synem po śmierci męża. Ks. Bronisław planował odwiedziny w Polsce. Skompletował wymagane dokumenty. W krótkim czasie zachorował i zmarł 25 XI 1973 roku w Uroczystość Chrystusa Króla ${ }^{153}$.

W 1963 roku władze komunistyczne republiki zamknęły kościół Opatrzności Bożej, wówczas ks. Chodanionek przeniósł się do ormiańskiej kaplicy cmentarnej w pobliżu dworca kolejowego przy ul. Azowskiej 11, która już wówczas była zamknięta. Ta kaplica służyła wiernym do momentu odzyskania kościoła Opatrzności Bożej w 1990 roku.

Polaków w stolicy żyło niewielu, więcej na prowincji. Od 1949 roku ks. Chodanionek był jedynym kapłanem obrządku łacińskiego w mołdawskiej republice liczącej 4 mln mieszkańców. Służył wiernym do śmierci w 1973 roku. Z oddalonej o ok. $1000 \mathrm{~km}$ Wileńszczyzny, stron rodzinnych księdza, przyjeżdżali wierni z dziećmi, które tam w Kiszyniowie przystępowały do I Komunii św. lub dorośli, którzy przyjmowali sakramenty święte ${ }^{154}$.

Ks. Bronisław był urodzonym artystą plastykiem i doskonałym organizatorem uroczystości religijnych. W chwilach wolnych reperował zegarki oraz wykonywał z gipsu kolorowe figury bożonarodzeniowe, które wykonywał z ogromnym zamiłowaniem. Odlewał je w gipsie, następnie ręcznie rzeźbił i malował. Takie komplety figur wykonał do kościoła w Winnicy, Czerniowcach i Odessie. Miał swoje hobby. W chwilach wolnych reperował zegarki. Największą radość sprawiało mu uruchomienie zegarka przeznaczonego już na straty. Usługi wykonywał nieodpłatnie.

152 W latach międzywojnia w centrum Kiszyniowa przy ul. Mieszczańskiej 9 w parterowym budynku mieścił się Dom Polski. W nim funkcjonowała czteroklasowa Szkoła Polska, z językiem polskim i rumuńskim. W sąsiedztwie Domu Polskiego na rozległym terenie stał kościół rzymskokatolicki (tzw. polski) pw. Opatrzności Bożej, zbudowany w połowie XIX w. przez tamtejszych Polaków. Kościół stanowił centrum życia religijnego Polaków, stanowiących ok. 90 \% tamtejszych katolików. Liturgia odprawiana była w języku łacińskim i polskim a także niemieckim i francuskim. Ówczesny proboszcz, ks. prałat Marek Glaser, wywodzący się z Niemców nadwołżańskich, biegle władał tymi językami. Parafia kiszyniowska należała do dekanatu Jassy w Rumunii. Przed inwazją radziecką w 1940 roku ks. Glaser wyjechał do Jass, gdzie został biskupem. Na jego miejsce przybył z Bender ks. Mikołaj Szczurek. T. Gaydamowicz, Mołdawia - kraj lat dziecinnych, „Jutrzenka”, nr 6/7 [51] z 2002 roku, s. 10-12.

${ }^{153}$ Żurek, Jeńcy na wolności, s. 40-50, 52.

154 Tamże, s. 43-45. 
Po jego śmierci w 1973 roku salezjanie na terenie Mołdawskiej SRR nie pracowali przez kilkadziesiąt lat.

\section{b) Republika Mołdawii}

Po rozpadzie ZSRR i proklamowaniu 25 VI 1990 roku suwerenności Mołdawii, powstało nowe państwo, które przyjęło ona nazwę Republiki Mołdawii ${ }^{155}$. Moldowa w języku rumuńskim to nazwa krainy od rzeki Mołdowy, leżącej między: Besarabią, Bukowiną, Siedmiogrodem, Wołoszczyzną i Dobrudżą, ograniczona rzekami: Prutem i dolnym Dniestrem oraz Karpatami. Republika graniczy od wschodu z Ukrainą a od zachodu z Rumunią.

Mołdawia jest jednym z najuboższych krajów kontynentu europejskiego. Przeżywa swoiste problemy społeczno-ekonomiczne w związku z transformacjami jakie dokonują się w tym kraju po uzyskaniu suwerenności państwowej. Także młodzież w okresie kształcenia potrzebuje pewnego rodzaju wychowawczego i formacyjnego działania opartego na wartościach chrześcijańskich. W tę pracę i formację pragną się włączyć na terenie Mołdawii salezjanie i salezjanki pracujące w sąsiedniej Rumunii. Rada Generalna Zgromadzenia wydała pozytywną opinię co do otwarcia do grudnia 2005 roku placówki salezjańskiej w Mołdawii. Zostanie ona powierzona inspektorii Włochy Północne Wschód (INE), w łączności z salezjańskimi placówkami w Rumunii. Planowana wspólnota będzie się składała ze współbraci pochodzących z różnych inspektorii, tworząc wspólnotę międzynarodową. Szczególnie włączona zostanie polska Inspektoria św. Stanisława Kostki (PLE) poprzez wysłanie swojego personelu. Zapoczątkowane dzieło przewiduje wysłanie początkowo dwóch współbraci na naukę języka i zebranie informacji na temat możliwości pracy salezjanów w tym kraju ${ }^{156}$.

\section{SALEZJANIE W FEDERACJI ROSYJSKIEJ}

Federacja Rosji powstała na bazie socjalistycznej republiki, gdzie salezjanie w przeszłości radzieckiej nie prowadzili żadnych dzieł. Taka możliwość zaistniała dopiero po proklamowaniu państwa Rosji. Salezjanie zainicjowali swoją pracę w Moskwie, następnie w Saratowie.

Obecnie salezjanie w Rosji pracują w 9 placówkach, w większości duszpasterskich. Na Syberii w dalekiej Jakutsji (Wschodnia Syberia), a właściwie w dwu miastach republiki; w jej stolicy: Jakutsji i w odległym od niego o 600 kilometrów Ałdanie. Te dwie placówki leżą na terenie Administratury Apostolskiej Syberii, gdzie bp Józef Werth pełni posługę pasterską. Pozostałe 7 placówek rozrzucone są

${ }^{155}$ Terytorium obecnej republiki, w latach 1918-1940 wchodziło w skład Rumunii (Besarabia), z tym że Mołdawia lewobrzeżna weszła w skład Ukraińskiej SRR, a w 1924 roku utworzono Mołdawską ASRR. Latem 1940 roku na mocy porozumienia między ZSRR i Rumunią Besarabia powróciła do ZSRR, powstała wówczas Mołdawska SRR.

${ }^{156}$ Działalność Rady Generalnej. Projekt Mołdawia, w: Dokumenty Rady Generalnej, Kraków Nr 387, Rok LXXXV październik-grudzień 2004 s. 57-58. 
w europejskiej części Rosji. Należą do nich: Gatchina-Sankt Petersburg, Moskwa (ul. Mała Gruzińska 19/2/22), Moskwa-Filii (ul. Mała Filewska 6/3), Oktiabrsk k. Moskwy, Rostov nad Donem, Samara i Sankt Petersburg. W wymienionych wyżej placówkach współbracia tworzą 4 wspólnoty zakonne z kanonicznym przełożonym, zwanym dyrektorem: Ałdan, Gatchina-Sankt Petersburg, Moskwa, Jakutsk $^{157}$.

Aspirantat salezjański w Gatchinie (obwód Leningrad). Niedaleko Sankt Petersburga, w Gatchinie na ul. Chkałowa 7 funkcjonuje od 1992 roku jedyna na terenie Rosji Salezjańska Szkoła Poligrafii i później otwarta Szkoła Biznesu (Marketingu). Na obydwu kierunkach uczy się około 200 uczniów (2005/2006), którzy mieszkają w internacie szkolnym. Praktykę zawodową odbywają w drukarni szkolnej. Wyposażenie Szkoły Poligraficznej należy do najnowocześniejszych w Rosji. Szkołę zainicjowali salezjanie włoscy, doświadczeni w prowadzeniu tego typu placówek dydaktycznych. Skład personalny wspólnoty salezjańskiej w Gatchinie jest międzynarodowy, z wyraźną przewagą współbraci włoskich.

Przełożonym domu w Gatchinie został ks. Onorino Pistellato - Włoch, kierownikiem szkoły ks. Giuseppe Pellizzari. W 2005 roku ks. Pistellato zastąpił ks. Vladimir Kabak.

Szkoła wypracowała wysoki poziom naukowy. Jej absolwenci bez trudności są zatrudniani w swoim zawodzie. Mimo, że uczniowie szkoły są w większości prawosławni, nie czują się obiektami ,prozelityzmu”. W szkole nie rezygnuje się w wychowaniu z wartości religijno-moralnych, a uczniowie posiadają całkowitą swobodę wyznaniową. Uczy się przede wszystkim odpowiedniego przygotowania do zawodu, z poszanowaniem w życiu wartości chrześcijańskich ${ }^{158}$.

Oprócz tego w Gatchinie powstała katolicka parafia Matki Bożej z Góry Karmel. Wspólnota parafialna liczy ok. 100 osób. Liturgię sprawuje się w odbudowanej części zrujnowanego kościoła - właściwie w jego pierwotnym prezbiterium. Odbudową życia religijnego w tej parafii podjął się wieloletni jej proboszcz, polski salezjanin, ks. Wiesław Dąbrowski.

Przy parafii funkcjonuje salezjańskie Oratorium młodzieżowe. W sumie pracuje tam 4 salezjanów (3 Włochów i 1 Słowak). Obowiązki dyrektora i proboszcza pełni od 2004 roku ks. Vladimir Kabak.

Dla tamtejszych dzieci salezjanie z Gatchiny organizują trzytygodniowe wakacyjnie obozy letnie. Liczba ich uczestników dochodzi nawet do 300. W zorganizowaniu tej formy wypoczynku uczestniczą także młodzi prawosławni animatorzy, przygotowani przez salezjanów i grupę animatorów włoskich. Wspólnie z katolickimi animatorami są współtwórcami wakacyjnych przeżyć i wypoczynku dla gatchińskich dzieci159.

Parafia Wniebowzięcia NMP w Moskwie (katedra). Pod koniec 1991 roku przybył z Żupran na Białorusi do Moskwy ks. Józef Zaniewski. Został miano-

${ }^{157}$ Weder, Znaki nadziei, s. 59.

${ }^{158}$ Tamże, s. 43.

${ }^{159}$ Tamże, s. 44. 
wany proboszczem parafii katedralnej Niepokalanego Poczęcia NMP przy Małej Gruzińskiej. Od tego momentu rozpoczęła się walka o świątynię, zamienioną w czasach stalinowskich na fabrykę. Została erygowana parafia. Otrzymał nominację proboszcz, ale brak było kościoła parafialnego. Początkowo liturgię sprawowano ,pod chmurką".

Proces przejmowania świątyni postępował etapami. Na początek Msze św. odprawiane były na schodach przed drzwiami wejściowymi. Następnie ,zdobyto" przedsionek, by w jakiś czas później, nie bez ofiar ze strony wiernych, wejść wreszcie do wnętrza. Budynek kościoła okazał się przedzielony sztucznie trzema piętrami. Początkowo udało się odzyskać tylko połowę parteru, druga jego część i trzy piętra pozostawały we władaniu rozmaitych instytucji państwowych. Aktualnie świątynia służy katolikom wielu narodowości. Odprawia tam liturgię w języku polskim, rosyjskim, angielskim i po łacinie. Jest katedrą biskupią metropolity abpa Tadeusza Kondrusiewicza ${ }^{160}$.

Ks. Zaniewski był pierwszym w historii Zgromadzenia salezjaninem, który przybył do Moskwy i zainicjował tu w 1991 roku pracę duszpasterską. Znał dobrze ówczesne realia, w których mu przyszło żyć i pracować. Dzięki pozytywnym cechom swojej osobowości (pracowity, skromny, pobożny) z czasem zyskał sobie uznanie także i władz miejskich stolicy. Sprawował we wspólnocie moskiewskiej funkcję pierwszego przełożonego i proboszcza katedry. Od 2002 roku ks. Zaniewski pełnił funkcję proboszcza na Małej Gruzińskiej, dyrektorem został ks. Augustyn Dziędziel.

Kiedy dzisiaj znamy historię życia ks. Józefa, ciśnie się pytanie: czy ów skromny młodzieniec, przed 30 laty wyjeżdżający z Białoruskiej SRR do Polski, z pragnieniem służby Bogu, mógł przypuszczać, że do takich zadań Pan Bóg go skieruje i takie będą tego owoce? ${ }^{161}$.

W 1996 roku, uprzedzając 80. rocznicę Objawień fatimskich, dzięki staraniom abpa Tadeusza Kondrusiewicza z Moskwy, wraz z biskupami tego regionu, rozpoczęła się peregrynacja figury Matki Bożej Fatimskiej na terytorium Rosji i Kazachstanu.

Przesłanie fatimskie dotyczyło losów Rosji i wiary w tym kraju, stąd znajomość tych Objawień i wezwań z nich płynących wśród katolików rosyjskich jest stosunkowo duża.

$\mathrm{Z}$ terytorium Rosji, często $\mathrm{z}$ daleka, przybywało do stolicy wielu pielgrzymów, pragnących uczestniczyć w spotkaniu z Matką Bożą w znaku fatimskiej figury. Żarliwa modlitwa, radość i rozrzewnienie określały atmosferę tych dni nawiedzenia. Na koniec Matka Boża udała się na Plac Czerwony. Po zaparkowaniu samochodu z figurą w pobliżu Kremla, kapłani wzięli statuę Matki Bożej na ramiona i ponieśli w kierunku Placu Czerwonego. Czegoś podobnego w tym miejscu jeszcze nie było. Zarówno zwiedzający, mieszkańcy stolicy jak i służby milicyjne u bram Kremla obserwowali zdarzenie z ogromnym zainteresowaniem, bez jakiejkolwiek interwencji. Księża postawili figurę Matki Bożej na bruku Placu

\footnotetext{
160 Tamże, s. 29.

161 Tamże, s. 49-50.
} 
Czerwonego i odmówili dziesiątek różańca za Rosję i Kościół w Rosji. Ten moment upamiętniono na zdjęciach, które zamieściła prasa światowa ${ }^{162}$.

Plac Czerwony to miejsce zdarzeń tragicznych i heroicznej historii Rosji, miejsce mauzoleum wodza rewolucji październikowej, symbol potęgi imperialnej, która świadomie była budowana na wartościach przeciwnych Bogu i religii. To miejsce dotknęła obecność Matki Bożej w znaku fatimskiej figury, bo Matka Boża Fatimska patronuje pracy Kościoła katolickiego w Rosji.

Na Jubileusz Odkupienia roku 2000 ustawiony został przed katolicką katedrą i uroczyście poświęcony krzyż, który przypomina tamtejszym katolikom o zbawczej misji Chrystusa na ziemi

W pracy duszpasterskiej przy parafii katedralnej w Moskwie pomagają siostry salezjanki, przybyłe tam w 1991 roku z Polski. Pierwszą z nich była siostra Danuta Kamińska (zm. 2006), która przybyła z dwiema młodziutkimi siostrami ze swego zgromadzenia.

Nie miały własnego domu. Korzystały z różnych mieszkań, trzykrotnie się przeprowadzały, bez możliwości wyboru sąsiadów. Warunki materialne mają skromniejsze od księży. Nieustannie są zasilane pomocą finansową z domów macierzystych w Polsce. Katechizują dzieci, młodzież i dorosłych. Prowadzą schole liturgiczne. One pierwsze przychodzą do kościoła i ostatnie z niego wychodzą. Prowadzą zakrystię, dbają o estetykę i czystość wszystkiego co ma związek z liturgią. Apostołują pracą, swoją postawą, także i strojem zakonnym. Wszędzie i zawsze są w habitach, co nie jest ani łatwe, ani proste. Duchowa sytuacja młodzieży to jeden z głównych powodów przybycia sióstr na Wschód. Źródłem ich sukcesów $\mathrm{w}$ pracy $\mathrm{z}$ młodzieżą jest kierowanie się w kontaktach $\mathrm{z}$ nimi zasadą stanowiącą fundament wychowania $\mathrm{w}$ duchu św. Jana Bosko: rozumem - religią - sercem. Stąd siostry salezjanki stosunkowo łatwo znajdują kontakt z młodzieżą, która swoje życiowe problemy przeżywa w ostrzejszej formie ${ }^{163}$.

Od 1993 roku pracował w Moskwie w katedralnym kościele ks. Kazimierz Szydełko, w tym osiem lat (do 2004) odpowiedzialny był za Dom Dzieci Ulicy, który rozpoczął swoją działalność na ul. Gruzińskiej 19, a po paru latach funkcjonowania znalazł locum w nowo wybudowanym gmachu na Filii.

Dom Dziecka w Moskwie-Filii. Problem „dzieci ulicy” nie jest rzadkością w wielkich aglomeracjach miejskich. Uwidocznił się jaskrawo po zmianach ustrojowych jakie wystąpiły po rozpadzie imperium radzieckiego. Salezjanie w Moskwie podjęli troskę o dzieci z rodzin niepełnych, rozbitych, patologicznych i sieroty, których w mieście jest wciąż dużo. Ci koczują po dworcach, stacjach metra, w poddaszach domów.

Na początek salezjanie moskiewscy zdecydowali, aby wszystkie pomieszczenia znajdujące się na parterze ich moskiewskiego domu przy ul. Gruzińskiej 19 przeznaczyć na „Prijut” dla dzieci bez opieki. Przez ten „Prijut” przeszło już kil-

\footnotetext{
${ }^{162}$ Weder, Znaki nadziei, s. 76-78.

${ }^{163}$ Relacja ks. Zdzisława Wedera z 6 XI 2006 roku - Kraków (zb. aut.).
} 
kadziesiąt dzieci, które tam mieszkały, uczyły się, były żywione, znalazły ciepły dom, dobrą rozrywkę i poczucie, że są kochane.

Mimo że nie ogranicza się tam wolności dzieci, w ich wychowaniu uwzględnia się wartości chrześcijańskie. Wychowankowie „Prijutu” uczestniczą w niedzielnej Mszy św. w katedrze moskiewskiej, zajmując pierwsze ławki. Moskiewski dom dziecka jest wystarczającą wizytówką młodzieżowej działalności salezjańskiej w Moskwie, której duszą był od 2001 roku jego dyrektor, ks. Kazimierz Szydełko, a w 2004 roku zastąpił go ks. Yevgen Yurchenko. Od 2005 roku pełni tam obowiązki dyrektora (p.o.) ks. Stanisław Buchta, dotychczasowy proboszcz z Bóbrki na Ukrainie ${ }^{164}$.

Obecny „Prijut” ma już swój własny i obszerny dom usytuowany w dzielnicy Moskwy - Fili na ul. Mała Filewska 6/3 dla 50 dzieci. Budynek o powierzchni 2400 metrów kwadratowych wybudowany został staraniem Zgromadzenia Salezjańskiego i dzięki pomocy finansowej sponsorów z Niemiec: salezjańskiej prowincji monachijskiej, prokury misyjnej w Bonn, na czele z ks. Bruno Bauerem, oraz społeczeństwa niemieckiego. Oni są „ojcami chrzestnymi” dzieła tak bardzo potrzebnego dzieciom stolicy Rosji. Ta instytucja dobroczynna posiada obecnie status domu dziecka, a to daje większe możliwości dla pełnego rozwoju fizycznego, duchowego i intelektualnego podopiecznych ${ }^{165}$.

W prowadzeniu domu na Fili zaangażowana jest grupa osób świeckich, pedagogów i ludzi kochających dzieci, którzy pod kierownictwem salezjanów spełniają misję dobroczynną na rzecz młodych.

Dom rekolekcyjny w Oktiabrsku (rejon Luberetskij). W miejscowości Oktriabrsk na ul. Kooperativnaja 3 przełożeni Okręgu erygowali w 1995 roku nowicjat salezjański. Pierwszym dyrektorem domu i magistrem nowicjuszów został ks. Roman Rzepecki. Po nim przełożonym i formatorem kandydatów do Zgromadzenia został ks. Antoni Murziński - do 2000 roku. Na jeden rok (2000/2001) przejął te same obowiązki ks. Zdzisław Weder.

Socjuszem nowicjatu byli: jako pierwszy ks. Władysław Kloc, następnie ks. Marek Poniewierski, ks. Jerzy Królik i ks. Jerzy Grobelak.

Funkcję administratora domu pełnił (od 10 XII 1997 do 27 II 2002) ks. Józef Bogusz.

Po kilku latach funkcjonowania nowicjatu, gdy znacznie zmniejszyła się liczba powołań z Okręgu, w 2001 roku przełożeni zlikwidowali nowicjat w Oktiabrsku. Mieści się tam dom rekolekcyjny i Centrum Młodzieżowe. Od 2005 roku kieruje nim ks. Grzegorz Głowienka, redaktor „Światowej Radości”, miesięcznika młodzieżowego wydawanego przez salezjański Okręg Wschodni. W ten sposób salezjanie ewangelizują młodzież. Starają się być wychowawcami w wierze, w środowiskach ludowych, posługując się w tym celu głównie środkami społecznego przekazu ${ }^{166}$.

\footnotetext{
${ }^{164}$ Relacja ks. Zdzisława Wedera do ks. W. Żurka z 6 XI 2006 roku - Kraków (zb. aut.).

${ }^{165}$ Relacja ks. Kazimierza Szydełko z 18 XII 2006 roku - Mińsk (zb. aut.).

${ }^{166}$ Relacja ks. Grzegorza Głowieka z 14 XII 2006 roku - Oktiabrsk (zb. aut.).
} 
Parafia pw. Ostatniej Wieczerzy w Rostowie. Po rocznej pracy w Lidzie (IX 1992-IX1993) ks. Edward Mackiewicz wyjechał do Polski. Jednak parafianie lidzcy nieustannie prosili, aby ponownie przybył na Białoruś. W czasie spotkania dnia 28 X 1993 roku z administratorem apostolskim Rosji europejskiej, abpem Tadeuszem Kondrusiewiczem mianowany został ks. Edward Mackiewicz proboszczem w Rostowie nad Donem. Objął równocześnie parafię Wniebowzięcia NMP w Nowoczerkasku.

W Rostowie Niemcy wybudowali ok. 30 kaplic i byli bardzo ruchliwi. Aby temu w jakiś sposób przeciwdziałać ze strony katolików, skierowano tam ks. Edwarda do pracy duszpasterskiej. Pod jego kierownictwem salezjanie wybudowali w Rostowie kościół i dom parafialny. Na początku września 2000 roku przybył do pomocy jako wikariusz parafialny ks. Antoni Murziński, dotychczas dyrektor i magister nowicjuszów w Oktiabrsku. Gdy dnia 10 IX 2002 roku proboszcz z Rostowa wracając z Polski nie został wpuszczony do Rosji, ks. Antoni Murziński przejął po nim probostwo ${ }^{167}$. Po pięciu latach duszpasterzowania w Rostowie - w 2006 roku przybył do Bóbrki na Ukrainę ${ }^{168}$.

Parafia pw. Najświętszego Serca Jezusowego w Samarze. Samara - dawny Kujbyszew -to milionowe miasto Federacji Rosyjskiej, w odległości ok. tysiąca kilometrów na południowy wschód od Moskwy.

Świątynia katolicka jest jedną z najbardziej okazałych budowli w mieście, jakby nieoficjalny symbol miasta oraz powszechnie uznawany za najbardziej znany kościół diecezji saratowskiej (św. Klemensa).

Pierwsi katolicy na terytorium obecnej Samary byli Niemcami, zaproszonymi w drugiej połowie XVIII w. przez Katarzynę Wielką do osiedlenia się w rejonie Wołgi. W momencie nadania Samarze statusu miasta prowincjonalnego w 1851 roku żyła tam liczna społeczność katolicka. Po rozbiorach Polski zaborca rosyjski zsyłał na Syberię i w region Wołgi polskich patriotów. W połowie XIX w. zamożny kupiec - katolik Jegor Annajew zaoferował pomoc w zbudowaniu kościoła katolickiego w Samarze i ofiarował dużą sumę pieniędzy na ten cel. Kolejne polskie powstanie narodowe przeciwko carowi rosyjskiemu opóźniło to wydarzenie o połowę wieku. Bowiem gdy w 1864 roku budowa kościoła była na ukończeniu, został on sprzedany luteranom ${ }^{169}$. Efektem kolejnych starań katolików było wybudowanie w Samarze kościoła drewnianego a następnie murowanego w la-

${ }^{167} \mathrm{~W}$ tej sytuacji przybył do Wilna. Tu nie wyraził zgody na jego pracę kard. Audyrus Juzoas Backis, więc ks. Edward przyjechał na Żytomierzyznę, do Korostyszewa, gdzie pracował od października 2002 roku do marca 2004 roku. Relacja ks. Edwarda Mackiewicza z 20 II 2006 roku Przemyślany (zb. aut.).

${ }^{168}$ Relacja ks. Antoniego Murzińskiego z 20 II 2006 roku - Przemyślany (zb. aut.).

${ }^{169}$ Sprzedaż kościoła katolickiego było wynikiem represji rosyjskich na polskich katolikach po powstaniu styczniowym z 1863 roku. Od tego momentu świątynia służyła luteranom i katolikom. Lecz na tym tle dochodziło do konfliktów, stąd katolicy sprawowali liturgię po domach prywatnych i nieustannie czynili starania o odzyskanie sprzedanej świątyni katolickiej. Efektem zabiegów u gubernatora Samary i w urzędzie policji było zezwolenie na budowę nowego kościoła. Relacja ks. Władysława Kloca z 19 XII 2006 roku - Samara (zb. aut.). 
tach 1898-1902, według projektu moskiewskiego architekta Foma Osipowicza Bogdanowicza; jego poświęcenia dokonał dnia 12 II 1902 roku ks. F. Ignacy Łapszys ${ }^{170}$, tamtejszy proboszcz. Kościół został wybudowany w stylu gotyckim $\mathrm{w}$ formie krzyża, $\mathrm{z}$ dwiema wieżami we frontowej części kościoła. Jego iglice były widoczne praktycznie z każdego miejsca miasta. Miejscowa społeczność polska zakupiła w Wiedniu organy. W tamtych latach była to najwyższa budowla miasta $(47 \mathrm{~m})$.

W ramach represji komunistycznych ucierpiała tamtejsza społeczność katolicka. Dnia 18 I 1930 roku władze zamknęły kościół z powodu ,znikomej ilości katolików mieście". Wprawdzie przez jakiś czas katolicy odprawiali liturgię w kaplicy cmentarnej (dziś stacja kolejowa), jednak wkrótce nastąpiło aresztowanie księdza i wielu katolików, a społeczność katolicka powoli się rozpraszała. Potem budynek kościelny był używany przez polską Szkołę Podstawową, szkołę baletu oraz kino Szturm. W latach 1941-1994 mieściło się w nim Muzeum Historii Naturalnej.

W wyniku pierestrojki i reform, została zarejestrowana w Samarze społeczność katolicka. Pierwsza Msza św. została odprawiona we wrześniu 1991 roku, druga w wigilię Bożego Narodzenia 24 XII 1991 roku. Stały jeszcze wówczas w świątyni eksponaty muzealne. Duszpasterzował tam wówczas ks. Józef Gunczaga ze Słowacji, który w marcu 1993 roku mianowany został na proboszcza w Ufie. Po nim dwa miesiące pracował ks. Tadeusz Benesz, kapłan diecezjalny. Proboszczem został tam w 1993 roku ks. Thomas Donaghy ${ }^{171}$, salezjanin pochodzący z Północnej Irlandii i były misjonarz w Republice Południowej Afryki. Dzięki niemu Kościół katolicki odzyskał prawo własności do budynku w 1995 roku $^{172}$. Podczas mszy celebrowanej dnia 16 XI 1996 roku kościół noszący teraz wezwanie Najświętszego Serca Jezusowego został ponownie poświęcony przez abpa moskiewskiego Tadeusza Kondrusiewicza. Jest to jedyny kościół katolicki tej aglomeracji miejskiej. Zbudowany w stylu neogotyckim, odzyskany kilka

170 Ks. Łapszys Ignacy (1869-1894 - przed 1939). Absolwent seminarium duchownego w Petersburgu. Kapłan archidiecezji mohylewskiej. Od 1901 roku proboszcz parafii Samara w Rosji europejskiej. Aresztowany i więziony w Samarze. Po zwolnieniu był sparaliżowany. Ostatnie lata jako chory przebywał na Litwie w diecezji poniewieskiej (par. Linkuva). Zmarł przed 1939 rokiem. R. Dzwonkowski, Losy duchowieństwa katolickiego w ZSRR 1917-1939. Martyrologium, Lublin 1998, s. 330.

${ }^{171}$ Ks. Donaghy Thomas, ur. w lipcu 1933 roku w Dungiven, obwód Derry, Irlandia. Święcenia kapłańskie otrzymał w 1962 roku. Pracował w duszpasterstwie w Anglii, Południowej Afryce (1968-1992) i Rosji. Od początku 1992 roku przez rok pracował w Moskwie, odprawiając w dzień powszedni Mszę św. w mieszkaniu własnym a w niedzielę na schodach kościoła, w owym czasie używanego jako pracownia inżynierska; dziś jest to katedra Niepokalanego Poczęcia NMP. W latach 1993-2001 pracował w Samarze mając za zadanie odbudowanie parafii i nakłonienie miejscowych władz do zwrotu kościoła społeczności katolickiej oraz jego renowację. Z powodu choroby musiał odejść z parafii i wrócić do Irlandii na leczenie. Obecnie angażuje się w duszpasterstwo przy katedrze w Moskwie.

${ }^{172}$ Do momentu zwrotu kościoła społeczności katolickiej (1991-1995) Msza św. była sprawowana od czasu do czasu na jego schodach, nieco później regularnie w niedzielę w muzeum. 
lat temu, starannie odbudowany, służy tamtejszym katolikom w liczbie ok. 300 osób.

Co uderza obserwatora przybyłego po raz pierwszy do tej parafii? Między innymi to, że w czasie niedzielnej Mszy św. wierni z brewiarzy odmawiają Jutrznię, liturgiczną modlitwę Kościoła. Mężczyźni przygotowują ołtarz do liturgii i sprawują pieczę nad grupą ministrantów. Czytania biblijne i śpiewy międzylekcyjne w czasie Mszy św. wykonują świeccy. Każdy uczestnik Eucharystii zostaje zaopatrzony w teksty pieśni do śpiewania. Po Mszy św. młoda parafianka przewodniczy niedzielnej Drodze Krzyżowej dla dzieci.

W parafii działa kilkuosobowa grupa, która otacza szczególną opieką każdego przybysza, który pojawi się w kościele. Ci aktywiści parafialni informują przybysza w tematyce religijnej, a jeżeli wyraża takie życzenie, odsyłają go do proboszcza.

Grupa kilku katechetów z upoważnienia proboszcza prowadzi kilkumiesięczne przygotowania dzieci i młodzieży do przyjęcia chrztu i innych sakramentów. W czasie wakacji letnich wspólnota organizuje obozy dla dzieci prowadzone również przez świeckich ${ }^{173}$.

To bardzo aktywne zaangażowanie świeckich w życie lokalnego Kościoła wydaje konkretne owoce, m. in. w postaci pierwszych powołań zakonnych i kapłańskich z tej parafiii ${ }^{174}$.

Po kilku latach pracy, ze względu na stan zdrowia, ks. Donaghy musiał opuścić Samarę. Po nim probostwo przejął 16 VIII 2001 roku ks. Władysław Kloc ${ }^{175}$, który pracuje tam do dzisiaj i pełni także obowiązki przełożonego (p.o.) dyrektora. W parafii funkcjonuje salezjańskie Oratorium młodzieżowe ${ }^{176}$.

Do pomocy ks. Klocowi w Samarze, w 2003 roku przybył ks. Józef Bogusz, jako wikary, który od 23 VI 2003 roku obsługiwał kościół w Otradnoje. Dnia 16 XII 2005 roku przeniesiony został do Korostyszewa na Ukrainę. Kolejnymi wikariuszami parafialnymi byli w Samarze: ks. Petrus Petrosjan (9 XI 2005-24 IX 2006), ks. Aleksander Samojłow (od 19 IX 2004)

Dom formacyjny w Sankt Petersburgu. W 1993 roku zostało erygowane Międzydiecezjalne Seminarium Duchowne w Moskwie, gdzie studiowali klerycy z europejskiej części Federacji Rosyjskiej. Gdy odzyskano budynki i kościół pobernardyński w Petersburgu, tam zostało przeniesione seminarium. Tam również podjęli studia w 1998 roku salezjańscy klerycy z Okręgu Wschodniego. Mieszkali we własnym domu formacyjnym powstałym w 1997 roku w mieście, a na zajęcia

${ }^{173}$ Weder, Znaki nadziei, s. 64-66.

174 Tamże, s. 64-66.

${ }^{175}$ Ks. Kloc Władysław, ur. 7 IV 1939 roku w Chodaczkowie w głęboko religijnej rodzinie. Pierwszą profesję złożył 26 VII 1958 roku w Kopcu. Święcenia kapłańskie przyjął 13 VI 1969 roku w Krakowie. Pracował w duszpasterstwie 14 lat (Środa Śląska, Wrocław, Przemyśl). Kolejne 14 lat pracował na misjach w Afryce w Zambii. Ostatecznie pracuje na Wschodzie. Relacja ks. Władysława Kloca z 19 XII 2006 roku - Samara (zb. aut.).

${ }^{176}$ Relacja ks. Zdzisława Wedera z 8 XI 2006 roku - Kraków (zb. aut.). 
uczęszczali do seminarium. Bywały roczniki, że w seminarium tamtejszym studiowało ok. 20 kleryków salezjańskich.

Pierwszym przełożonym domu formacyjnego został ks. Henryk Boguszewski, wychowawcą - ks. Augustyn Dziędziel, ekonomem - ks. Wiesław Dąbrowski (junior). W 2000 roku ks. Boguszewski został mianowany inspektorem Okręgu Wschodniego, a dyrektorem domu został ks. Krzysztof Cabała. Salezjańscy klerycy studiowali w tym seminarium do 2003 roku. W tym roku powrócono do wcześniejszej praktyki kształcenia kandydatów ze Wschodu w seminariach salezjańskich w Polsce. Do pracy przyjechał z Lublina ks. Zbigniew Lato, który od 2004 roku pełni funkcję przełożonego. Na miejscu funkcjonuje jedynie kaplica wewnętrzna dla współbraci. Obecnie na ul. Kotovskiego 4 w budynku mieści się centrum duchowości, a placówka spełnia rolę Ośrodka rekolekcyjnego oraz domu pielgrzyma. Na miejscu prowadzą salezjanie świetlicę środowiskową oraz ośrodek młodzieżowy ${ }^{177}$.

Parafia pw. św. Klemensa w Saratowie (diec. Saratów z siedzibą biskupa w Samarze). Miasto w europejskiej części Rosji. W połowie stycznia 1992 roku desygnowany został do pracy parafialnej w Saratowie ks. Edward Mackiewicz. Z Moskwy wyjechał wspólnie z ks. Romanem Rzepeckim dnia 3 II 1992 roku, proboszczem z Saratowa. Ks. Edward pracował w Saratowie do września tego roku, kiedy to przeniesiony został do ks. Szoki w Lidzie. Po ks. Rzepeckim parafię w Saratowie przejął we wrześniu 1994 roku ks. Jacek Falkowski, który przybywszy bezpośrednio z Polski, podjął tam trud budowy kościoła. Ks. Falkowski w listopadzie 1999 roku został skierowany do Borun na Białoruś, gdzie udał się w grudniu tego roku. Tam pracował jako proboszcz do lipca 2000 roku i wrócił do Polski ${ }^{178}$.

Parafia w Ałdanie. Miasto w Republice Sacha-Jakutsja. Tam na dalekiej Syberii w 1991 powstała parafia obsługiwana przez salezjanów. Najpierw funkcjonowała prowizoryczna kaplica. Jej duszpasterzem był od 1994 roku ks. Juraj Kysel. Współbracia należeli do wspólnoty zakonnej w Jakutsku. W 1998 roku zastąpił go ks. Igor Hozjak jako proboszcz i dyrektor domu zakonnego pw. błog. Luigi Versiglia przy ul. Proletarskaja 1. Przy parafii otwarto salezjańskie Oratorium młodzieżowe.

Aktualnie pracuje w Ałdanie czterech kapłanów z przełożonym ks. Peterem Bicákiem ${ }^{179}$.

Parafia i dom salezjański w Jakutsku. Jakutsk miasto w azjatyckiej części Federacji Rosyjskiej, stolica Republiki Sacha, zwanej inaczej (ros.) Jakutsją, port nad rzeką Leną. Ponad 40\% powierzchni leży poza kręgiem polarnym. Miasto powstało wokół kozackiego grodu warownego założonego w 1632 roku. Od XVIII

${ }^{177}$ Relacja ks. Zbigniewa Lato 18 XII 2006 roku - Sankt Petersburg (zb. aut.).

${ }^{178}$ Relacja ks. Jacka Falkowskiego z 13 XII 2006 roku - Lubin (zb. aut.).

${ }^{179}$ Towarzystwo Salezjańskie i Córki Maryi Wspomożycielki. Elenko 2006-2007, Kraków 2006, s. 148 . 
w. miejsce zesłań politycznych, m.in. licznych Polaków oraz baza rosyjskiej kolonizacji Dalekiego Wschodu. Od 1851 roku miasto obwodowe, od 1922 roku stolica Jakutsji, rejon łagrów. Miasto otulone syberyjską tajgą, gdzie temperatura w styczniu utrzymuje się od 40 do 50 stopni poniżej zera. W lipcu od 2-19 stopni powyżej zera. Mieszkańcy odziani w futra z puszystymi czapkami, na nogach w obuwiu ze skóry reniferów. Są przyzwyczajeni do życia i pracy w trudnych warunkach klimatycznych.

Parafia w Jakutsku jest jedną z dwu placówek salezjańskich na terenie rosyjskim w części azjatyckiej. Najpierw salezjanie wybudowali dom z kaplicą przy ul. Dzierżyńskiego 14. Następnie rozpoczęli budowę kościoła. Pierwszym proboszczem i dyrektorem w Jakutsku został ks. Józef Pravda (Słowak). W 1998 roku zastąpił go ks. Andrzej Porubczin. Tamtejsza wspólnota liczyła zawsze dwóch kapłanów i w niektórych latach dodatkowo do dwóch kleryków odbywających praktykę wychowawczą w Domu Młodzieży im. Księdza Bosko, otwartym w 1996 roku przy ul. Luraszowa (Kurashova) 34.

Interesującą historię opowiadał inspektorowi ks. Zdzisławowi Wederowi Administrator apostolski dla katolików azjatyckiej części Rosji, czyli Syberii - bp Józef Werth w Nowosybirsku. W mieście mieszkała pani Gertruda, Niemka. W czasach komunizmu, gdy na każdym kroku odczuwano brak kapłanów, ona była animatorką życia religijnego. Organizowała spotkania modlitewne po domach i im przewodziła. Uczyła dzieci i dorosłych katechizmu, udzielała im chrztu św. W tamtym czasie ochrzciła ok. 2000 osób. Oczywiście na panią Gertrudę doniesiono do władz, że gromadzi ludzi wierzących na spotkania religijne, co było prawem surowo zabronione. Miał miejsce i taki wypadek, że w czasie wspólnotowej modlitwy w jednym $z$ domów przyszedł oficer milicji. Przekazano jej wiadomość, że oczekuje na nią przedstawiciel władzy. Odpowiedziała, że teraz się modli, niech poczeka, jak skończy. Po zakończeniu modlitwy wyszła do czekającego oficera i rzekła: jestem do waszej dyspozycji. Milicjant zaniemówił zaskoczony. Popatrzył uważnie i z szacunkiem, zasalutował, odchodząc rzekł: wy dobra kobieta ${ }^{180}$.

W roku 2006/2007 pracuje w Jakutsku trzech współbraci: ks. Andrej Parubčin - dyrektor i proboszcz, kl. Ján Havaňák odbywający salezjańską praktykę pedagogiczną i brat zakonny - František Španik ${ }^{181}$.

\section{KSZTAŁCENIE KANDYDATÓW DO ZGROMADZENIA Z OKRĘGU WSCHODNIEGO}

Jak już zostało powiedziane, w całym Imperium Sowieckim funkcjonowały z łaski władz komunistycznych tylko dwa seminaria duchowne: w Kownie i Rydze.

Spośród czterech litewskich seminariów działających tam jeszcze w czasie II

${ }^{180}$ Aktualnie, na szczeblu diecezjalnym,toczy się proces beatyfikacyjny Gertrudy. Weder, Znaki nadziei, s. 59-61.

${ }^{181}$ Towarzystwo Salezjańskie i Córki Maryi Wspomożycielki. Elenko 2006-2007, s. 151. 
wojny, po 1945 roku władze pozostawily jedynie uczelnię w Kownie. Pozostałe seminaria w Wilnie, Telszach i Wiłkowyszkach zostały zlikwidowane. W tej sytuacji placówka w Kownie zyskała status seminarium międzydiecezjalnego, kształcącego duchowieństwo dla całej Litewskiej Republiki. Jeszcze przed odzyskaniem przez Litwę niepodległości, w 1989 roku reaktywowano seminarium w Telszach. W 1993 roku przywrócono seminarium w Wilnie a w późniejszym czasie w Mariampolu dla diecezji wołkowyskiej. Obecnie mamy na Litwie stan z 1945 roku, jeśli chodzi o placówki naukowe kształcące duchowieństwo dla Litwy.

Białoruś była pierwszym (poza krajami bałtyckimi) krajem dawnego imperium, gdzie zostało powołane do życia 1 IX 1990 roku seminarium duchowne, w byłym klasztorze bernardyńskim w Grodnie, dzięki inicjatywie ówczesnego administratora apostolskiego Białorusi bpa Tadeusza Kondrusiewicza (1989-1991). Początkowo kształciło ono kandydatów również z Gruzji, Kazachstanu, Ukrainy, a także Polaków z Litwy, których ze względów językowych nie przyjmowano do seminariów litewskich. Powołane zostało także seminarium w Pińsku, gdzie kształcą się także klerycy dla Mińska i Mohylewa.

Obecnie najwięcej uczelni teologicznych otwarto na Ukrainie. Swoje seminaria mają trzy największe diecezje: lwowska, kamieniecko-podolska i kijowsko-żytomierska, chociaż żadne z nich nie mieści się w stolicy diecezji. W 1991 roku powstało seminarium w Gródku Podolskim dla diecezji kamienieco-podolskiej. Kolejne powstało w 1995 roku w Worzelu dla diecezji kijowsko-żytomierskiej i w 1996 roku w Brzuchowicach pod Lwowem dla archidiecezji lwowskiej. W nim kształcą się także klerycy z diecezji łuckiej. We wszystkich seminariach ukraińskich wprowadzono tzw. kurs zerowy, przygotowujący przyszłych kleryków do życia seminaryjnego.

Własnych uczelni nie mają na razie Łuck i Zakarpacie (diec. mukaczewska). Kościół na Wołyniu jest niewielki i nie ma wielu powołań. Podobnie jest na Zakarpaciu, gdzie dodatkowo dochodzi problem językowy, bowiem w tym rejonie dominują Słowacy i Węgrzy, stąd większość spośród tamtejszych kandydatów kształci się w tych właśnie krajach.

Seminarium Duchowne w Rosji powstało w 1993 roku w Moskwie. Dnia 1 września tego roku w kościele Niepokalanego Poczęcia NMP w czasie uroczystej Mszy św. Nuncjusz Apostolski - abp Francesco Colasuono zainaugurował działalność placówki naukowej kształcącej kleryków. Później seminarium przeniesiono do Sankt Petersburga ${ }^{182}$. Obecnie nad Newą, oprócz kleryków zakonnych, kształcą się klerycy z Rosji i Syberii, Kazachstanu, Gruzji i Białorusi.

Od początku lat dziewięćdziesiątych ubiegłego stulecia polskie prowincje

${ }^{182}$ Seminarium Duchowne w Rosji powstało w 1993 roku w Moskwie. Kiedy jednak udało się odzyskać kościół i budynki dawnego seminarium archidiecezji mohylewskiej w St. Petersburgu, tam przeniesiono uczelnię. Tam kształcą się alumni z Rosji i Syberii, Gruzji, Kazachstanu i Białorusi. W Nowosybirsku - stolicy Syberii, a jednocześnie w siedzibie administratora apostolskiego tego regionu - funkcjonuje proseminarium, gdzie przyszli kandydaci na kleryków przygotowują się do wstąpienia do seminarium. Nad ich formacją czuwają jezuici. Podobna uczelnia istnieje w Karagandzie (Kazachstan). Weder, Znaki nadziei, s. 87-88. 
salezjańskie podjęły trud formacji i kształcenia kandydatów do Zgromadzenia z państw po rozpadzie Związku Sowieckiego, czyli z Okręgu Wschodniego. W tym czasie na 4 prowincje polskie funkcjonowały 3 nowicjaty: w Czerwińsku nad Wisłą (dla Prowincji św. St. Kostki i Prowincji św. Wojciecha), Swobnicy (od 1983 roku dla Prowincji św. Wojciecha) oraz w Kopcu k. Częstochowy (dla Prowincji św. Jana Bosko i św. Jacka).

W nowicjacie w Czerwińsku w latach 1991-1995 formację odbywało 24 kandydatów ze Wschodu; w Swobnicy w latach 1992-1994 nowicjat ukończyło złożeniem profesji 2 nowicjuszy; natomiast w Kopcu 1992-2006 rozpoczynało 24 kandydatów, a z tych 18 złożyło profesję zakonną.

W Wyższym Seminarium Duchownym Towarzystwa Salezjańskiego w Krakowie i Lądzie ${ }^{183}$ (1991-1998) odbywali studia seminaryjne kandydaci z Okręgu Wschodniego w latach 1990-2005 z przerwą pięcioletnią (1998-2003), gdy studiowali w Moskwie i w Sankt Petersburgu. W sumie przez studia seminaryjne w Krakowie przeszło 61 alumnów. Z tej liczby święcenia kapłańskie otrzymało 12. Wykaz powyższy nie obejmuje danych z Seminarium w Łodzi ${ }^{184}$ za lata 1996-1998 i 2003-2005.

System kształcenia przyszłego duchowieństwa na Wschodzie powoli się stabilizuje. Powstają nowe placówki, które w najbliższym czasie powinny całkowicie zaspokoić potrzeby poszczególnych Kościołów lokalnych. Wprawdzie odczuwa się brak wykładowców, jednak powoli przyszłe kadry, wywodzące się już z miejscowego duchowieństwa, zdobywają stopnie naukowe w Rzymie i w innych krajach. Brakuje również fachowej literatury i podręczników w rodzimych językach. Ale i ta sytuacja z każdym rokiem staje się coraz lepsza. Nadejdzie taki moment, że i salezjańscy kandydaci do kapłaństwa ze Wschodu będą się kształcić w tamtejszych seminariach diecezjalnych lub własnym, utworzonym dla Okręgu Wschodniego.

${ }^{183}$ Seminarium w Lądzie (filozofia i teologia) do 1995/96 wspólne dla Prowincji św. Wojciecha i św. St. Kostki.

${ }^{184}$ Seminarium w Łodzi od 1996/97 kształci alumnów z Prowincji św. St. Kostki. 


\section{MÖGLICHKEITEN UND FORMEN SALESIANISCHER SEELSORGE IN DER NACHKRIEGSWIRKLICHKEIT AUF DEM GEBIET DER EUROPÄISCHEN SOWJETREPUBLIKEN}

\section{Zusammenfassung}

Infolge der Entscheidungen der Siegermächte und der Friedensverträge, die den 2. Weltkrieg beendeten, wurde die Ostgrenze unsres Staates nach Westen verschoben und die dahinter liegenden Gebiete der Sowjetunion einverleibt. Die bisher in den Ostgebieten der Republik lebenden Polen wurden zur sogenannten Repatriierung und zur Ausreise in die Volksrepublik Polen gezwungen. Aber ein Teil der polnischen Bevölkerung, darunter auch Priester, fügte sich diesem Druck nicht. Sie blieben in ihrer Heimat, nun allerdings als Bürger des Sowjetstaates.

Nach der Rückkehr der meisten in der bisherigen Diözese Wilna arbeitenden Salesianer nach Polen im Jahre 1945 blieben dort nur noch 9 Mitbrüder zurück, die bis zu ihrem Lebensende in der dortigen Seelsorge arbeiteten. Von ihren Oberen in Polen offiziell als nicht zum Orden gehörig angesehen, nahmen sie im Rahmen ihrer Möglichkeiten und unter Wahrung höchste Vorsichtsmaßnahmen Kontakt mit den Ordensoberen in Polen auf, unter anderem aus Anlass des Besuches von Familienangehörigen oder von Mitbrüdern aus Polen. Mit der Zeit fuhren dann einige von ihnen aus dem Wilnaer Gebiet zur Arbeit nach Weißrussland, in die Ukraine und nach Moldawien, wo sie bis zu ihrem Lebensende unter manchmal extremen Bedingungen arbeiteten.

Ein brennendes Problem der katholischen Kirche in Ostmitteleuropa in der zweiten Hälfte des 20. Jahrhunderts bildete die Seelsorgearbeit in der UdSSR, vor allem in den Gebieten der Litauischen, der Weißrussischen und der Ukrainischen Sowjetrepublik, wo ein ziemlich hoher Prozentsatz katholischer Bevölkerung lebte. Die Zahl der damals unbesetzten Pfarrstellen nahm von Jahr zu Jahr zu, in dem Maße, wie die bisherigen Seelsorger aus der Vorkriegszeit wegstarben. Manchmal waren sie aus unterschiedlichen Gründen nicht imstande, den seelsorglichen Bedürfnissen der dortigen Gläubigen Genüge zu tun. Ihre religiöse Tätigkeit wurde von Seiten der staatlichen Behörden durch die Ausübung des Kultes betreffende Einschränkungen von oben und durch andere Schikanen sowohl gegen die dort arbeitenden Geistlichen als auch gegenüber den dortigen Gläubigen sehr erschwert. Jede einzelne Pfarrgemeinde musste von den politischen Behörden bestätigt werden, und die Pfarrer konnten ihren Pflichten nur auf der Grundlage einer staatlichen Bevollmächtigung nachkommen; außerdem musste jeder Priester zur Ausübung seelsorglicher Aktivitäten eine sogenannte „Sprawka” erhalten. Die Repressionen gegen die katholische Kirche in der Sowjetzeit traten in den einzelnen Republiken mit unterschiedlicher Intensität auf. Etwas mehr Freiheit und Arbeitsmöglichkeiten als woanders gab es in der Litauischen SSR.

Erst die Perestrojka von Michail Gorbatschow brachte dann eine gewisse „Erwärmung”. Der Zerfall der UdSSR im Jahre 1991 und die Proklamierung der Eigenstaatlichkeit durch die bisherigen Republiken führten zu wesentlichen Veränderungen in der dortigen Kirche lasteinischen Ritus'. Obwohl in den proklamierten Staaten die bisherige Gesetzgebung der Kirche gegenüber in Kraft blieb (Registrierung der Pfarrei nur für einen bestimmten Zeitraum, Kirchenkomitees - die sogenanten „Zwanziger”), können die Gläubigen ihren Glauben frei praktizieren, auch wenn die katholische Religion in den einzelnen Staaten recht unterschiedlich behandelt wird.

In der wachsenden Zahl reaktivierter Pfarreien entstand die Notwendigkeit, die seelsorgliche Betreuung durch Priester zu gewährleisten, vor allem durch Priester aus dem Ausland. Die dortigen offiziellen Hirten der Kirche (d.h. die Bischöfe) baten die katholische Kirche in Polen um Hilfe, weil die polnischen Priester durch ähnliche Erfahrungen des Lebens unter dem sozialistischen System für die Seelsorgearbeit in diesen Gebieten geradezu prädestiniert waren. In späterer Zeit begannen dann auch Priester aus anderen europäischen Ländern und sogar von anderen Kontinenten dort zu arbeiten. 
Um den dortigen Bedürfnissen entgegenzukommen, entschieden sich auch die Salesianer, Priester zur Seelsorge nach Weißrussland (Belarus), Litauen und in die Ukraine zu schicken, wo sie vor dem Krieg gearbeitete hatten, aber auch in andere Republiken. Auf diese Weise initiierten sie ihre Präsenz in der Russischen Föderation, in Georgien und in Kasachstan. Anfangs übernahmen sie Pfarreien, organisierten das Ordensleben in den erigierten Gemeinschaften und begannen dann schließlich auch mit der Jugendarbeit, indem sie Jugendzentren und salesianische Oratorien einrichteten. Die nach dem Osten geschickten Salesianer gehörten zunächst weiterhin zu ihren eigenen salesianischen Inspektorien in Polen, aus denen sie stammten, aber seit dem 8. Dezember 1994 gehören die Niederlassungen in Belarus, Litauen, der Ukraine, Russland und Georgien jetzt zum neugeschaffenen Ostbezirk unter dem Patronat der Unbefleckten Empfängnis Unserer Lieben Frau mit Sitz in Moskau. Ein Oberer im Rang eines Provinzials leitet und animiert die in diesem Bezirk arbeitenden Salesianer aus aller Welt. Im Jahre 2005 wurden die litauischen Salesianer und die dortigen Niederlassungen auf eigenen Wunsch der italienischen Inspektorie St. Karl Borrömäus mit Sitz in Mailand angegliedert. In dieser Zeit baten die in der Ukraine arbeitenden Salesianer des byzantinisch-ukrainischen Ritus um ihren Austritt aus dem Ostbezirk. Auf Beschluss des Generaloberen P. Pascual Chavez wurde für sie die ukrainische Delegatur „Maria - Hilfe der Christen” erigiert. Heute sind die Salesianer auf dem Gebiet der ehemaligen UdSSR von Wilna bis Jakutsk in Sibirien, von St. Petersburg bis Odessa und Lemberg (Lviv) in der Ukraine aktiv.

Der Beitrag der polnischen Salesianerprovinzen zur Entwicklung der salesianischen Aktivitäten in diesen Gebieten besteht vor allem in der Hilfeleistung bei der Formation und Ausbildung der von dort stammenden Ordenskandidaten. Diese Hilfe begann prinzipiell schon in der zweiten Hälfte der achtziger Jahre des vorigen Jahrhunderts. Gleichzeitig kann man, wenn von dieser Unterstützung durch die polnischen Salesianer die Rede ist, nicht umhin, doch zumindest an das Engagement des früheren Delegierten des Generaloberen P. Augustyn Dziędziel zu erinnern, der bereits vor der Entstehung besserer Bedingungen für eine offenere Seelsorge- und Erziehungsarbeit auf dem Gebiet der ehemaligen Sowjetrepubliken dieser Angelegenheit viel Mühe und Sorge gewidmet hat. 